\title{
Review
}

\section{Stem Cell Transplantation Therapy and Neurological Disorders: Current Status and Future Perspectives}

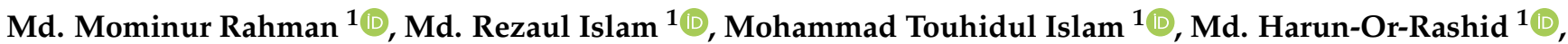 \\ Mahfuzul Islam ${ }^{1}$, Sabirin Abdullah ${ }^{2, *}$, Mohammad Borhan Uddin ${ }^{1}$, Sumit Das ${ }^{1}$, Md. Saidur Rahaman ${ }^{1} \mathbb{D}$, \\ Muniruddin Ahmed ${ }^{1}$, Fahad A. Alhumaydhi $\left.{ }^{3}{ }^{(}\right)$, Talha Bin Emran ${ }^{4} *{ }^{\circ}$, Amany Abdel-Rahman Mohamed ${ }^{5}$,

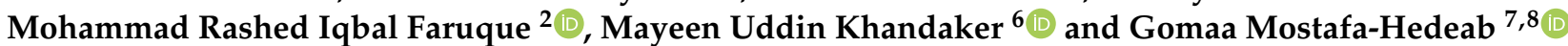

check for updates

Citation: Rahman, M.M.; Islam, M.R.; Islam, M.T.; Harun-Or-Rashid, M.; Islam, M.; Abdullah, S.; Uddin, M.B.; Das, S.; Rahaman, M.S.; Ahmed, M.; et al. Stem Cell Transplantation Therapy and Neurological Disorders: Current Status and Future

Perspectives. Biology 2022, 11, 147. https://doi.org/10.3390/biology 11010147

Academic Editors: Xinhua Shu Zhiming He, Mustafa Nazıroglu and Chiara Villa

Received: 10 November 2021 Accepted: 29 December 2021 Published: 7 January 2022

Publisher's Note: MDPI stays neutral with regard to jurisdictional claims in published maps and institutional affiliations.

Copyright: (C) 2022 by the authors. Licensee MDPI, Basel, Switzerland. This article is an open access article distributed under the terms and conditions of the Creative Commons Attribution (CC BY) license (https:// creativecommons.org/licenses/by/ $4.0 /)$
1 Department of Pharmacy, Faculty of Allied Health Sciences, Daffodil International University, Dhaka 1207, Bangladesh; mominur.ph@gmail.com (M.M.R.); md.rezaulislam100ds@gmail.com (M.R.I.); touhidul.ph@diu.edu.bd (M.T.I.); rashid685@diu.edu.bd (M.H.-O.-R.); mahfuzemon87@gmail.com (M.I.); mdborhan630@gmail.com (M.B.U.); sumitd00420@gmail.com (S.D.); mdsaidur569@gmail.com (M.S.R.); drmuniruddin@gmail.com (M.A.)

2 Space Science Center, Universiti Kebangsaan Malaysia, Bangi 43600, Selangor, Malaysia; rashed@ukm.edu.my

3 Department of Medical Laboratories, College of Applied Medical Sciences, Qassim University, Buraydah 52571, Saudi Arabia; f.alhumaydhi@qu.edu.sa

4 Department of Pharmacy, BGC Trust University Bangladesh, Chittagong 4381, Bangladesh

5 Department of Forensic Medicine and Toxicology, Zagazig University, Zagazig 4511, Egypt; amanyrahman292@gmail.com

6 Centre for Applied Physics and Radiation Technologies, School of Engineering and Technology, Sunway University, Bandar Sunway 47500, Selangor, Malaysia; mayeenk@sunway.edu.my

7 Pharmacology Department \& Health Sciences Research Unit, Medical College, Jouf University, Sakaka 72446, Saudi Arabia; gomaa@ju.edu.sa

8 Pharmacology Department, Faculty of Medicine, Beni-Suef University, Beni-Suef 62521, Egypt

* Correspondence: dr_sabirin@ukm.edu.my (S.A.); talhabmb@bgctub.ac.bd (T.B.E.)

Simple Summary: This review highlights the scope of available treatment options for neurological diseases, especially stem cell transplantation therapy, which provides new hope. The health sector continues to grow effectively, developing new ideas for saving lives and making complex processes more accessible, such as stem cell transplantation therapy. The treatment of individual neurological disorders is associated with different pathophysiological conditions, so transplantation therapy must be performed under optimal conditions with minimal risk. The promise of stem cell transplantation increases every day, with excellent animal models and small-scale observations in human trials. Stem cell therapy provides satisfactory data that support rational therapeutic purposes.

Abstract: Neurodegenerative diseases are a global health issue with inadequate therapeutic options and an inability to restore the damaged nervous system. With advances in technology, health scientists continue to identify new approaches to the treatment of neurodegenerative diseases. Lost or injured neurons and glial cells can lead to the development of several neurological diseases, including Parkinson's disease, stroke, and multiple sclerosis. In recent years, neurons and glial cells have successfully been generated from stem cells in the laboratory utilizing cell culture technologies, fueling efforts to develop stem cell-based transplantation therapies for human patients. When a stem cell divides, each new cell has the potential to either remain a stem cell or differentiate into a germ cell with specialized characteristics, such as muscle cells, red blood cells, or brain cells. Although several obstacles remain before stem cells can be used for clinical applications, including some potential disadvantages that must be overcome, this cellular development represents a potential pathway through which patients may eventually achieve the ability to live more normal lives. In this review, we summarize the stem cell-based therapies that have been explored for various neurological disorders, discuss the potential advantages and drawbacks of these therapies, and examine future directions for this field.

Keywords: neurodegenerative diseases; neurons; Parkinson's disease; red blood cell; stem cell; stroke 


\section{Introduction}

Aging is a biological phenomenon, and in humans, aging is often associated with undesirable physiological issues, including the development of neurological diseases [1]. Older nervous systems are less capable of neuronal regeneration due to the growth of inhibitory microenvironments that prevent axonal repair. Current research is aimed at the promotion of alternative cell-based approaches, including some that have been tested in limited clinical trials [2]. Neurological disorders can be categorized into three main types: diseases associated with neuronal loss from specific brain regions, such as Parkinson's disease (PD) and multiple sclerosis (MS); diseases related to the neuronal loss subsequent to acute damage, such as stroke; and diseases associate with impaired cellular functions, such as epilepsy [3]. The etiologies that lead to the development of brain abnormalities are often multifactorial, including aging, environmental factors, chronic stress, traumatic brain injury, and gene mutations such as those identified in amyloid precursor protein (APP), presenilin-1 and -2 , or apolipoprotein E (ApoE), which have all been associated with the development of neurodegenerative diseases [4].

Health researchers have profoundly investigated neurodegenerative disorders, employing various strategies to identify permanent cures [5]. One approach that has been heavily investigated is stem cell (SC) transplantation. SCs are widely believed to have significant potential for the treatment of a wide range of human diseases [6,7]. SCs are unspecialized germ cells that can differentiate into specialized cells that play specific roles in biological systems. The pluripotent properties of stem cells might be harnessed to compensate for neuronal loss or injury in the central nervous system (CNS) [8]. SC transplantation methods have become a very popular focus of recent research. A double-blind, sham-controlled surgery was performed in 2001 on PD patients and showed convincing results, encouraging researchers to progress to clinical trials $[9,10]$.

Alzheimer's disease (AD) is a progressive neurodegenerative disorder and the characteristics of this disorder include difficulty in performing daily tasks, confusion, and memory loss [11]. Current Alzheimer's disease therapies are not very effective, most probably due to the huge loss of neurons in the brain. Therefore, cell-replacement therapies, including induced pluripotent stem cell (iPSC)- or human embryonic stem cell (ESC)-derived neural cells may prove beneficial in treating AD individuals, especially the patients who would not benefit from typical pharmacological treatments [12].

A recent study showed that the introduction of autologous hematopoietic SC (HSC) transplantation (aHSCT) treatments for patients with multiple sclerosis (MS) reduced the mortality rate from $7.3 \%$ during $1995-2000$ to $1.3 \%$ during $2001-2007$, with mortality rates continuing to fall to $0.7 \%$ during $2008-2016$ and $0.2 \%$ during 2012-2016 [13]. MS is an immune-mediated disease [14]; unlike other standard immune-targeted drugs, aHSCT is designed to reset the immune system rather than suppress it [15-17]. Understanding the history of SC transplantation and the current state of SC research can provide a better perspective concerning the potential future applications of SC technologies [18]. Recent efforts have been extended to identifying methods to stimulate SC proliferation within the adult CNS and the protection of neurons and glial cells produced by endogenous stem cells. The translation of these exciting technological advances from the laboratory into clinically valuable therapies represents the next step in SC research $[19,20]$.

The purpose of this review was to describe the scope of available treatment options for neurological diseases. Current treatment options are limited, and drug approval rates for new therapies remain poor compared with other therapeutic areas. SC therapy provides hope for many patients; however, this hope should be tempered by the realization that the scientific and medical communities have yet to fully unravel the complexities of SC biology and provide satisfactory data that support the rational, evidence-based application of SCs for therapeutic purposes. Few studies have progressed into extensive, pivotal investigations using randomized clinical trial designs. Obtaining results from such studies 
will be essential for SC therapies to gain the necessary approvals for their application as mainstream treatments in the future.

\section{Characteristics of Various Stem Cells Utilized for Therapeutic Applications}

\subsection{Embryonic Stem Cells and Induced Pluripotent Stem Cells}

Embryonic SCs (ESCs; Figure 1) have long been utilized in numerous neurodegenerative transplantation models. In 2002, Isacson demonstrated that undifferentiated mouse ESCs could incorporate into the striatum of a rat PD model, differentiate into dopaminergic (DA) neurons, and restore the loss of motor function [21]. A few years later, two groups described the implantation of primate ESCs isolated in vitro into PD model monkeys [22] and rats [23], demonstrating the ability to integrate into the striatum, differentiate into tyrosine hydroxylase $(\mathrm{TH})+$ neurons, and partially restore motor function. Isolated ESCs can be induced to differentiate into various cells, such as oligodendrocyte precursors [24], which can relocate and differentiate into oligodendrocytes, which myelinate neuronal axons. Some ESCs can remain in an undifferentiated state [25], playing a trophic role in diminishing inflammation and maintaining the ventral myelin segments. Retinoic acid-pretreated ESCs have been shown to be effective for the treatment of rodent models of ischemia [26], in which neurological and behavioral tests indicated functional restoration. Motor neurons derived from ESCs have demonstrated the ability to alter motor functions in a rodent model of hereditary amyotrophic lateral sclerosis (ALS) [27], and multipotent neural progenitor cells (NPCs) have demonstrated the ability to reduce the clinical indications of MS in a mouse model of encephalomyelitis by reducing immune-mediated inflammation [28].

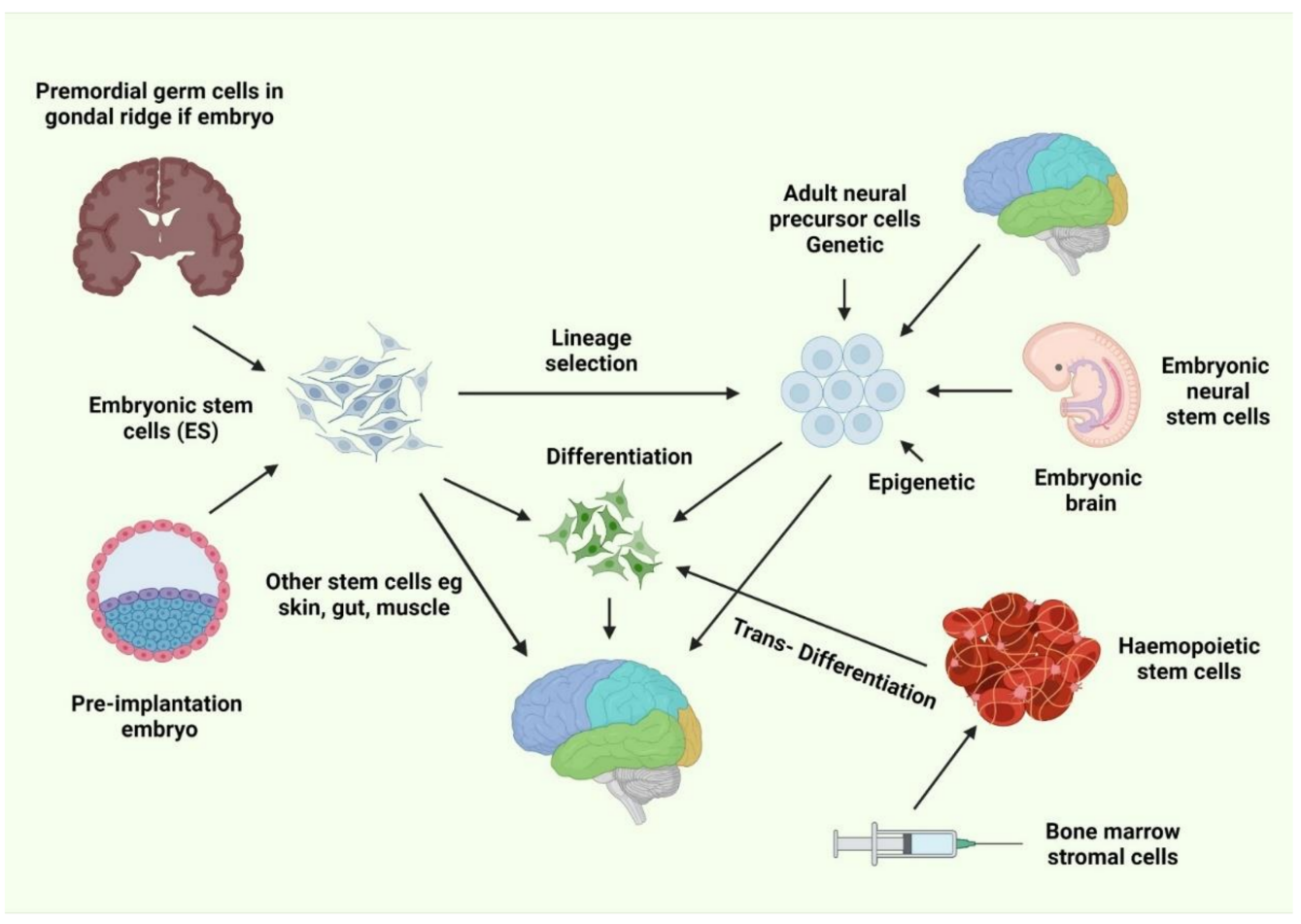

Figure 1. Different types of stem cells [29].

The utilization of undifferentiated ESCs has been associated with concerns about the potential to develop tumors and teratomas due to their capacity for continual proliferation. However, the induction of cell differentiation processes can diminish the multipotent ability of these cells, reducing the risks associated with transplantation; nonetheless, there remain numerous moral issues related to the use of ESCs. Other treatment avenues were introduced by Yamanaka in 2006 [30], who reported the ability to obtain early-stage undifferentiated cells from previously differentiated cells (generally fibroblasts), which have overcome the 
moral issues associated with the use of ESCs. These induced pluripotent SCs (iPSCs) were generated by activating four transcription factors genes: Oct3/4, Sox2, c-Myc, and Klf4. iSPCs have physiological and molecular characteristics similar to ESCs, including proliferative and differentiation capabilities. Furthermore, in vivo iPSC induction in mice has indicated that iPSCs have the incredible ability to establish developmental cell layers under empirical conditions, including the three primary germ layers (endoderm, mesoderm, and ectoderm), suggesting that the in vivo induction of iPSCs can achieve faster outcomes compared with the use of ESCs [31].

In animal models of neurological pathology, the similarities between iPSCs and ESCs make both of these cell types ideal for comparable applications. Human iPSCs have been shown to differentiate into DA precursor cells and relocate into the substantia nigra of PD rodent models, where they develop further into DA neurons over the long term and incorporate into the brain parenchyma. However, a few cells developed into tumor-like basal cells, adding to concerns regarding the safe application of these cells [32]. In another study, DA-differentiated iPSCs were isolated from a mixture of differentiated pluripotent cells using fluorescence-assisted cell sorting before implantation to decrease the risks of tumor formation [33]. Similar to ESCs, iPSCs were able to differentiate into terminal DA neurons; however, iPSCs presented more significant expression levels DA neuron-specific markers than ESCs, suggesting that iPSC-associated therapies might represent a viable avenue for the development of PD-specific treatments [34].

Importance of Pluripotent Stem Cells as Cell Replacements

In 2016, Takahashi and Yamanaka reported a pivotal, landmark study describing the ability to reprogram mouse fibroblast cells into a pluripotent state by activating four transcription factors OCT4 (Octamer-4), SYR (Sex Determining Region-Y, Box-2), KLF4 (Kruppel-like factor 4), and C-MYC (Cellular Myelocytomatosis Oncogenes) [30]. Since then, somatic cell lines derived from various species, including humans [35-37], pigs [38], mice [39], rhesus monkeys [40], marmosets [41], and sheep [42], have been successfully reprogrammed into iPSCs. Depending on the cell types, the use of fewer than four transcription factors is effective for reprogramming, and a single factor may be sufficient to obtain neural stem cells (NSCs) [43]. In addition to identifying the necessary transcription factors to derive iPSCs, various methods of transcription factor delivery have been explored. Retroviruses, lentiviruses, adenoviruses, and protein delivery methods have been used to generate iPSC lines. Temporally controlled distribution methods allow for the regulation of iPSC induction, and the use of various application sequences has facilitated the reprogramming of large numbers of cells.

Studies suggest that the expression of reprogramming factors is not required permanently, and iPSCs can efficiently differentiate into specific lineages after reprogramming; however, programmed cells (including both ESCs or other pluripotent cells) can activate endogenous pluripotency genes and silence exogenous ones. Several research groups have developed zero-footprint technologies to silence somatic cell genes permanently. Conventional techniques cannot distinguish these iPSCs from endogenous SCs. This technique has facilitated the efficient integration of Cre/Lox [44], piggyBac [45], and sleeping beauty transposons. Recently described techniques to achieve cell reprogramming include the use of specific plasmids [46] and other episomal strategies that are effectively diluted as the cells divide [47], affecting the levels of exogenous RNA [48], proteins [49], and other small molecules, reducing the probability of unintended integration events to near-zero [50].

Human iPSCs serve as a significant source of the generation of protein-specific and disease-specific pluripotent cells [51]. The use of differentiated iPSCs for in vitro studies of neurodegenerative disease represents a promising approach for understanding the mechanisms that drive these diseases because primary human neurons are not readily available for experiments (Figure 2). 


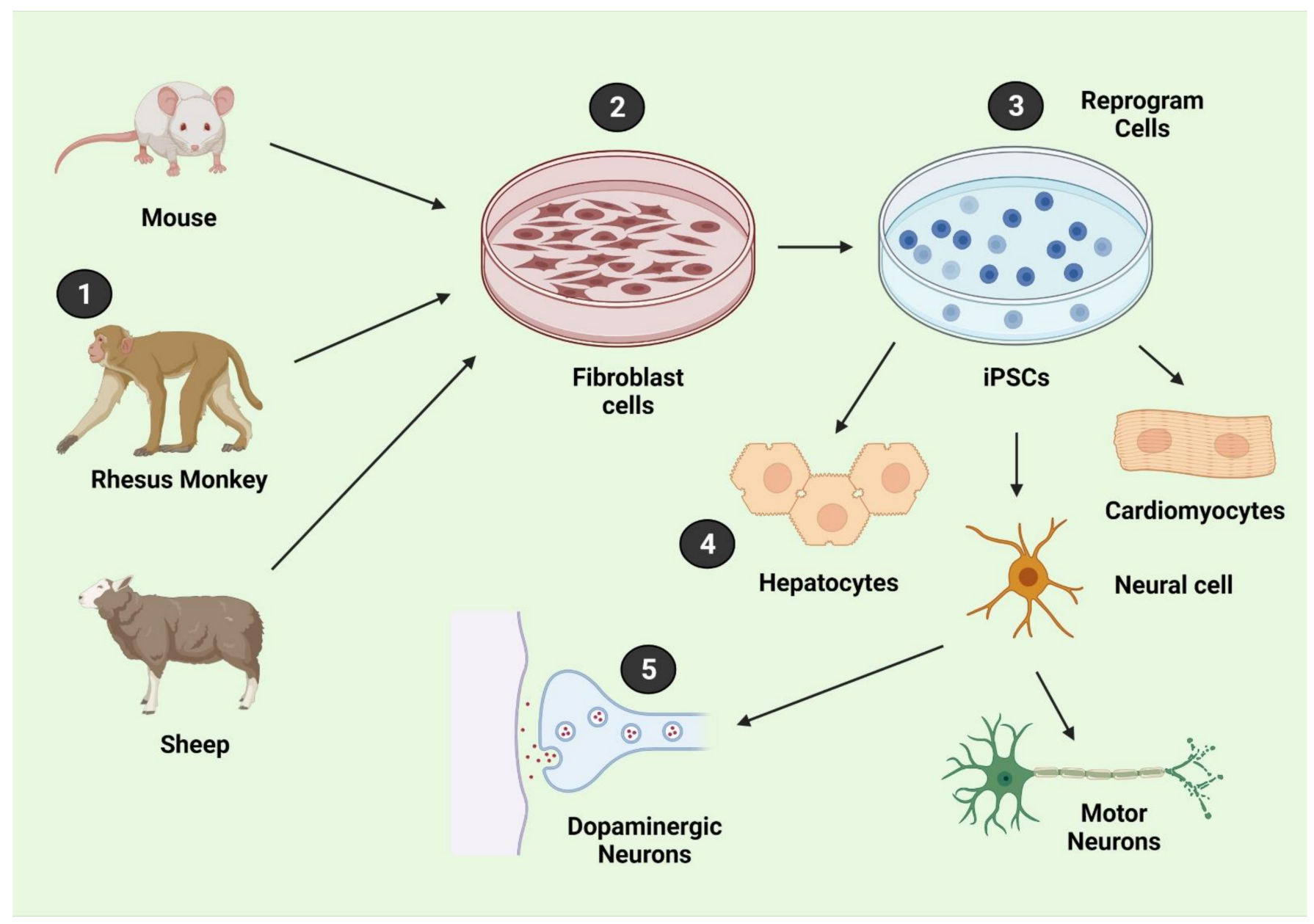

Figure 2. Pluripotent stem cells as cell replacements.

Cell-based analyses, including the use of MSCs, have been examined both preclinically and clinically. Many SC therapies are thought to treat disease by replacing degenerating neurons with healthy ones (Figure 3) [52-54].

However, the generation of research-grade autologous iPSCs is time-consuming and may require additional gene preparations to remove causative genes from patients with familial diseases. One alternative is the use of allogeneic cells to produce an HLA-matched iPSC line. To match $93 \%$ of the UK population, at least 150 homozygous HLA types from healthy donors are necessary to develop a tissue bank for the development of researchgrade iPSC lines [55], which would also result in the successful matching of $90 \%$ and $41 \%$ of the Japanese and Korean populations, respectively [56,57]. This prospect would involve considerable effort, requiring the complete characterization of the various PSC lines developed. As a proof of principle, the CRISPR-mediated knockout of HLA-B in iPSCs resulted in low immunogenicity [58].

\subsection{Neural Stem Cells}

Between 9.5 and 12 weeks of gestation, the telencephalon and diencephalon of the human embryo contain cells with all the attributes of foundational SCs. They multiply at a sufficiently rapid rate to be used for the treatment of human patients with various pathologies. These cells are capable of differentiating into neurons (with physiological electrical activity), astrocytes, and oligodendrocytes [59], similar to the capabilities observed for NSCs derived from rodents $[60,61]$. 


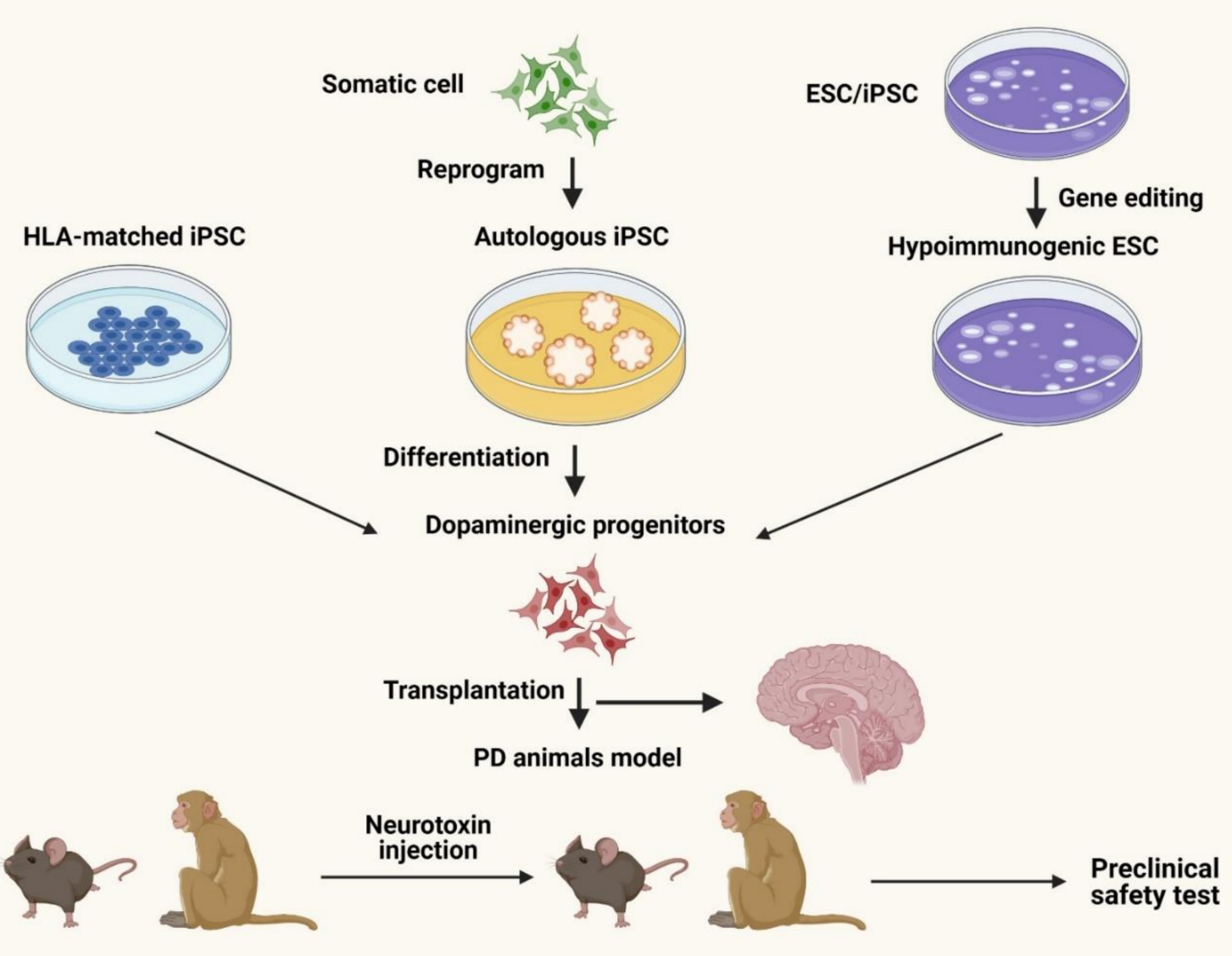

Figure 3. Stem cell analysis for Parkinson's disease. Dopaminergic progenitors could be obtained from induced pluripotent stem cells (iPSCs) of various origins, including somatic cells following epigenetic reprogramming or from in vitro fertilization (IVF)-derived human embryos. Human leukocyte antigen (HLA)-matched iPSCs or gene-altered hypoimmunogenic embryonic stem cells (ESCs)/iPSCs lower the likelihood of immunogenic cell death. Preclinical tests in neurotoxin-induced PD models in fleas and nonhuman primates exhibit promising beneficial effects [53].

Many animal models of neurological diseases have been effectively treated with NSCs. In a mouse model of MS, NSCs were shown to either replace damaged oligodendrocytes, allowing for the renewal of myelin sheets or the provision of trophic support through the release of various cytokines [62]. Similar cells that were administered intravenously to treat a spinal cord injury mouse model were unable to replace the damaged tissue but reduced inflammation by producing neurotrophic factors [63], suggesting that the pathologic environment can determine the outcomes for NSCs. Similar results were observed for the intraspinal transplantation of NSCs, with immunomodulatory outcomes rather than cellular replacement [64]. By contrast, the spinal infusion of human NSCs into various spinal sections of the superoxide dismutase 1 (SOD1) rodent model of ALS slowed disease progression, delayed disease onset, and increased survival rates [65].

\subsection{Mesenchymal Stem Cells}

Mesenchymal stem cells (MSCs) can be isolated from various differentiated tissues, including fat, ligaments, bone marrow stromal cells, dental pulp, skin, and fetal appendages [66-68]. Compared with ESCs or iPSCs, MSCs have some disadvantages; for example, MSCs present with fewer numbers, diminished proliferation capacity, and differentiation abilities with age, both in vitro and after in vivo transplantation [69]. To date, the ability of MSCs to differentiate freely has not been reported, and the one report indicating this ability, published in 2005 [70], was eventually retracted in 2010 [71]. 


\subsubsection{Bone Marrow MSCs}

Various reservoirs of undifferentiated MSCs have been identified in adults. These cells were initially discovered in the bone marrow and were once referred to as "marrow stromal cells"; however, they have since been identified in various tissues, including the umbilical cord and fat tissue. In vitro, MSCs can differentiate into various tissue types and may eventually play a substantial role in regenerative medicine [72]. Bone marrow MSCS (BMSCs) can differentiate into fat, ligament, bone, and most stromal cells found in the bone marrow in vivo, playing a significant role in the protection of HSCs and regulating the hematopoietic microenvironment, deep-rooted bone regeneration, and growth [73]. Myocardial infarction (MI) results in long-lasting cardiomyocyte damage. Due to their multipotent differentiation potential, minimal immunogenicity, and excellent transferability, BMSCs may serve as suitable seed cells for the treatment of cardiovascular disease $[74,75]$.

\subsubsection{Umbilical Cord Blood}

In vitro studies have indicated that umbilical cord blood (UCB)-MSCs have extensive cultural memories, can be developed at a large scale, and do not develop senescence, with more significant impacts. However, UCB-MSCs display less osteogenic potential than BMSCs. The potential uses for UCB-MSCs compared with BMSCs remain under debate, and these cells have not been assessed in vivo for the purposes of bone recovery. The most widely recognized cause of paralysis in children is cerebral palsy, for which no cure currently exists. Clinical trials are currently exploring the application of UCB-MSCs to treat children with cerebral palsy-induced paralysis. Although the utilization of UCB-MSCs for neuroprotective and neuroregenerative purposes is of incredible interest, the underlying mechanisms of action that result in these effects remain poorly understood [76-84].

\section{New Mechanisms of Grafted Stem Cells in Neuroregeneration}

The effects of transplanted cells on the body are numerous and can be attributed to various factors, including the integration of new cells providing support to endogenous cells and immunomodulatory effects [85]. The successful incorporation of graft-derived neurons into host networks can repair damaged brain regions and restore behavioral abnormalities. The behavioral recovery observed in patients following brain-graft surgeries has been hypothesized to be due to the establishment of new synaptic connections within the brain $[86,87]$.

In a study involving a patient with PD, researchers discovered that 24 years following transplantation, the detection of a graft-derived DA neuron-specific neuropeptide revealed the reinnervation of the putamen [88-90]. Glial impairments have been associated with various conditions, including stroke, MS, and Alzheimer's disease (AD), and the replacement of these cells has been examined [91], with significant positive results (described in more detail in the section "Glial Cell Transplantation"). Grafted cells can support the survival and recovery of host neurons through the secretion of neurotrophic factors, including a brain-derived neurotrophic factor (BDNF), a nerve growth factor (NGF), and a glial cellderived neurotrophic factor (GDNF), which are known to promote host neuron survival and promote transplanted cell survival, migration, and differentiation [92-94].

Another critical therapeutic mechanism involves the interaction between transplanted SCs and the immune system in the brain. Some studies have shown that SC transplantation reduces neuroinflammation, resulting in neuronal mortality [11]. In 2009, Pluchino et al. found evidence that the replacement of damaged or dead cells may not represent the fundamental mechanism underlying the apparent benefits following SC transplantation, indicating that immune modulation also plays a vital role in the observed improvements [95]. Consequently, the transplantation of SCs into the brain triggers several therapeutic mechanisms. Understanding which cell types produce positive effects, how these mechanisms are regulated, and which features may be impeding better outcomes, specifically, neuronal migration and integration into adult brain neuronal circuits, will improve the results of these therapeutic strategies [96]. 


\section{Recent Advances in the Treatment of Neurological Disorder}

\subsection{Parkinson's Disease}

The aggregation of alpha-synuclein ( $\alpha$-syn) is a distinctive characteristic of PD, and in vitro studies showed the promotion of fibrillation when $\alpha$-syn was combined with copper, iron, or other metal ions [97]. The bimetallic nature of PD has been characterized, indicating that when serum silver, cadmium, cobalt, iron, selenium, and zinc levels decreased, aluminum, calcium, chromium, mercury, magnesium, manganese, lead, and copper were detectable [98]. Other studies have reported that patients with PD have deficient serum copper levels compared with controls [99]. Other studies have revealed a substantial increase in the iron contents of patients with PD relative to controls. High iron levels can result in vulnerability for DA cells, making them susceptible to damage. Reduced neuromelanin levels can release free iron molecules, which could cause cellular toxicity [100], and the presence of free iron increases $\alpha$-syn aggregation.

$\mathrm{PD}$ is a chronic and progressive neurodegenerative disease that severely affects DA neurons [101]. In addition to the loss of DA neurons, the development of Lewy bodies (LBs) due to the deposition of $\alpha$-syn protein aggregates in the cytoplasm of neurons is a hallmark characteristic of PD pathology [102]. In recent years, the efficacy and efficiency of non-pharmaceutical therapeutic methods for PD, including gene therapy, microRNAs (miRNAs), SC therapy, and exosomes have been studied [103,104].

The intrinsic and prospective therapeutic characteristics of the MSC secretome and MSC-condition medium, which contains the factors secreted by MSCs, can be explained by protein analysis. The therapeutic effects of the human MSC (hMSC)-derived condition medium administered to a transgenic rat model of PD include an increase in DA neurons, a partial reversal of motor impairments, and improved histopathological measures [105]. In 2017, Shin et al. discovered that the miRNA miR-17-92 clusters in MSC-derived exosomes and induces neurogenesis [106], resulting in the stimulation of oligodendrogenesis and enhanced neuronal function. Despite the limited study, the current findings show that various stem cell sources (MSCs and dental SCs) have positive benefits for PD therapy, depending on their endogenous extracellular vesicle (EV) burden.

\subsection{Temporal Lobe Epilepsy}

Medically resistant epilepsy has been associated with several negative consequences, including increased risks of accidental injury, early death, cognitive decline, and a lower quality of life [107-109]. Temporal lobe epilepsy (TLE) is the most common form of epilepsy and is an almost medically intractable disorder [110,111]. Most TLE patients are medically refractory, and approximately 10-20\% present to epilepsy centers to obtain surgical interventions [112,113]. The aim of TLE surgical interventions is to eliminate seizures by removing the portion of the brain where seizures initiate [114,115], and a considerable proportion of TLE patients are not operative candidates. TLE patients with bilateral TLE can become permanently debilitated by the resection procedure, and even some unilateral resections result in the loss of active seizure focusing [116].

\subsection{Multiple Sclerosis}

MS is a common and disruptive disease that typically affects younger individuals [117]. MS affects individuals worldwide [118], and the underlying mechanism in disease development remains unclear. MS is a multifactorial disease associated with both genetic and environmental factors, such as vitamin D levels, ultraviolet B (UVB) exposure, EpsteinBarr infections (EBV), pollution, obesity, and smoking, increase the risks of developing MS [119]. MS is traditionally considered an autoimmune disease associated with T cell activity. However, the treatments targeted at B cells suggest that $\mathrm{T}$ cells may not be the only factor involved in this disease [120]. MS typically presents initially as relapsingremitting MS (RRMS), followed by recovery or the development of secondary progressive MS (SPMS), whereas some patients present initially with primary progressive MS (PPMS), an increasingly debilitating disease [121,122]. Although the specific mechanisms underly- 
ing MS development remain unknown, various contributing factors have been identified, including EBV, UVB, smoking, vitamin D, and genetics [123,124].

Approximately six types of parenterally administered MS drugs have obtained approval from the US Food and Drug Administration (FDA), including interferons, immunosuppressants, corticosteroids, glatiramer acetate, sphingosine-1-phosphate receptor modulators, and monoclonal antibodies, which significantly reduce the frequency and intensity of MS attacks in patients with recurrent episodes by targeting the immune system at various levels through different mechanisms. N, N-Dimethyltryptamine (DMT) has been shown to reduce the frequency of relapses but shows no effects on progressive MS or axonal damage. In addition, the reported efficacy, tolerability, and safety of DMT have varied between moderate and high levels, and continued treatments have been limited by the risk of severe side effects, including cardiomyopathy $[125,126]$.

In a mouse model of experimental autoimmune encephalomyelitis (EAE), $\mathrm{Li}$ investigated the influence of BMSC paracrine mechanisms, particularly the mediation of exosomes, on microglial polarization and motor function improvement [127]. Farinazzo further reported that reduced demyelination in the spinal cord following treatment with nanovesicles produced by adipose SCs resulted in decreased activity among CNS immune cells, including reduced microglial and $\mathrm{T}$ cell extravasation [128]. Because exosomes can penetrate the blood-brain barrier (BBB), they can deliver medicines to MS patients. The future of MS therapy is likely to be based on SC-derived exosomes for numerous reasons, including safety, the capacity to penetrate the BBB, and the ability to carry specific cargo, based on the existing literature.

\subsection{Huntington's Disease}

Huntington's disease (HD) is an inherited disease caused by an excessive number of CAG (cytosine-adenine-guanine) triplet repeats in the huntingtin gene. Copper and iron levels are higher in HD patients and model mice than in normal controls, particularly in the striatum [115], suggesting that environmental influences are unlikely to cause this dysregulation. In addition to increased copper levels, a group of copper regulatory genes has been associated with HD, and a therapeutic strategy has been proposed for HD that involves the use of a copper-binding protein [129]. Unlike copper, several movement disorders have been associated with changes in the iron levels in the brain, including PD, multiple organ atrophy, progressive supranuclear paralysis, and restless leg syndrome [130]. In addition to increased iron levels, increased manganese levels have also been reported [131].

The polyglutamine huntingtin protein, which is prone to aggregation, is transported to other cells via exosomes [132], and exosomes appear to be crucial to the development of HD pathogenesis. Exosomes have been examined for their potential to treat HD [133]. Lee et al. [134] found that exosomes from adipose-derived MSCs (ADMSCs) were able to regulate the pathogenic characteristics of an in vitro HD model by reducing intracellular mutant huntingtin aggregates and upregulating the expression of peroxisome proliferator-activated receptor-gamma coactivator 1 (PGC-1) and phospho-cAMP response element-binding protein (CREB). In addition to a decline in the intracellular expression level of RE1-silencing transcription factor (REST), the miR-124-target gene, the exosomemediated delivery of miR-124 to the striatum of R6/2 HD transgenic mice resulted in slight improvements in behavior [135].

\subsection{Amyotrophic Lateral Sclerosis}

ALS is considered a motor neuron illness associated with the debilitating loss of muscle control. In familial ALS cases, mutations in several genes have been identified, including C9orf72, superoxide dismutase 1 (SOD1), TAR DNA binding protein (TARDBP, TDP-43), fused in sarcoma (FUS), angiogenin (ANG), alsin (ALS2), senataxin (SETX), and vesicleassociated membrane protein-associated protein B (VAPB). This phenotype is believed to be the result of a combination of genetic and environmental factors. One of the most 
hereditary factors associated with ALS involves the mutation of the copper-zinc binding site of SOD1 [136].

An in vitro experiment revealed that the replacement of zinc with copper binding to SOD1 increases motor neuron toxicity [136]. Furthermore, cadmium can transform SOD1 by inducing metallothionein (MT) expression, disrupting zinc homeostasis. Specifically, after MT competitively binds zinc, MT enzymatic activity increases and the activity of SOD1 reduces due to the unavailability of zinc [137]. By contrast, cadmium can impair SOD1 activity by interfering with its secondary structure, causing misfolding and, in some instances, aggregation [120]. The absence of zinc, the presence of cadmium, or high levels of copper can all contribute to ALS progression. However, serum and cerebrospinal fluid (CSF) samples from advanced ALS patients reveal enhanced zinc and copper levels [138]. Increasing iron [139] and manganese [140] levels in the CSF of patients with ALS has also been documented through the assessment of plasma L-ferritin levels, which binds iron [141]. Increased iron levels are correlated with patients' longevity [142,143].

\subsection{Glial and Myelin Disorders}

The CNS features both neurons and non-neuronal neuroglial cells, including oligodendrocytes, astrocytes, and microglia. Neuroglial cells are typically more modest in size than neurons and are generally found in the cerebral cortex. Exploration shows that the proportion of glial cells to neurons in the male human brain is 4:1 [144], with oligodendrocytes representing the significant proportion $(75.6 \%)$, followed by astrocytes $(17.3 \%)$ and microglia (6.5\%) [145]. Glial cells, as valuable to neurons as veins, can improve the conduction speed of neuronal transmissions by facilitating saltatory conduction along myelinated axons, allowing neurotransmissions to pass between one neuronal ganglion to another. Glia also responds to CNS damage through the initiation of gliosis, which amplifies the numbers or sizes of glial cells. Previous neuroimaging studies of posthumous brains and genome-wide association studies (GWAS) have loosely associated changes in the gray matter with the occurrence of schizophrenia [146-148], supported by a few converging lines of proof. Psychosis has been associated with demyelinating disorders and neurological conditions associated with myelin destruction, including metachromatic leukodystrophy, adreno leukodystrophy, cerebrotendinous xanthomatosis, Schilder's sickness, NiemannPick infection, Pelizaeus-Merzbacher illness, and phenylketonuria [149,150].

\subsection{Disorders of the Hippocampus}

Hippocampal damage can negatively affect an individual's long-term recall abilities, including difficulty creating new memories [151]. The hippocampus also plays a vital role in short-term, episodic memory, and the bilateral loss of the hippocampus ceases the formation of new memories. Although memory formation initially relies on the hippocampus, memory recovery can occur without the hippocampus [152]. Research from a lesion study assessed the need for the para hippocampal, perirhinal, and entorhinal cortices to retrieve deep-rooted memories in animals [153]. The functions of the hippocampus remain controversial, despite wide-ranging studies examining the cellular systems and behavioral effects associated with the hippocampus. Positron emission tomography (PET) has been applied by multiple functional imaging studies, which showed no hippocampal activity during the memory analysis or retrieval [154-160]. Therefore, memory tasks performed during functional imaging studies may not adequately challenge the hippocampus, and no substantial increases in the metabolic requirements of the hippocampus are observed during memory retrieval based on PET studies.

\subsection{Frontotemporal Dementia}

Frontotemporal dementia (FTD) is characterized by changes in personality, behavior, and language abilities and belongs to a category of rare brain disorders. After AD and dementia with LBs, FTD is the third most common form of dementia [161]. In 1892, Arnold Pick [162] first recorded FTD, which was associated with unusual apathy, a lack of 
empathy, and reduced self-awareness. FTD was identified by Alois Alzheimer in 1911 and is commonly referred to as Pick's disease. People with FTD harbor irregular Pick bodies or Pick cells that are associated with disease development $[163,164]$. FTD is distinct from behavioral disorders, personality changes (such as primary psychiatric disease, tumors, and cerebrovascular disease), and other forms of non-degenerative dementia, especially from neurodegenerative diseases such as AD [165,166].

\section{Stem Cell Therapy and Treatment}

\subsection{Patient Selection for HSCT in Multiple Sclerosis}

aHSCT represents the most comprehensively studied comprehensive disease-modifying therapy (DMT), with limited-term toxicities. aHSCT is predominantly utilized to treat MS as an anti-inflammatory and immunomodulatory therapy, supported by considerable scientific evidence; however, aHSCT must be tolerated to be effective. Advantageous effects have been described for younger patients, including shorter illness durations, better Expanded Disability Status Scale (EDSS) scores, the reduced persistence of inflammatory disease, and the lack of other comorbidities [167-179]. The assessment of progress must evaluate both advances and compromises, such as the regression of stabilization of impairments or the development of new neurological conditions. aHSCT is more effective in subjects with RRMS than those with SPMS or PPMS [180].

\subsection{Stem Cell-Based Therapy for Alzheimer's Disease}

Various SCs have been explored for therapeutic purposes, including ESCs, iPSCs, BMSCs, and ADMSCs. Neurons derived from SCs can be incorporated into existing neural networks of the host brain [181]. In animal models, SC transplantation results in increased acetylcholine levels, which enhance cognition and memory [182]. ESC-derived NPCs can differentiate into astrocytes or neurons [183]. Human iPSCs have been produced from skin cells and can differentiate into neural cells. One study indicated that iPSCs generated from the fibroblasts of a patient with familial AD could differentiate into neurons and increase the salivary levels of amyloid $\beta(\mathrm{A} \beta 42)$. In addition, $\gamma$-secretase inhibitors were affected by the $A \beta$ found in the mucus produced by the diversified neurons, suggesting that these neurons have physiologic feedback responses when treated with $\gamma$-secretase inhibitors [170].

Nearly 50 million individuals have been estimated to suffer from dementia worldwide, accounting for approximately 800 billion dollars in medical expenditures, according to estimates from the Alzheimer's Association. The most common form of dementia is AD, which is characterized by progressive cognitive decline and the slow loss of psychological capacities. First reported in 1907 by Alois Alzheimer, AD is a multifactorial disorder, making the precise pathophysiological mechanism challenging to establish [184].

Several studies have investigated the potential for exosomes to serve as biomarkers for the early detection of AD or as a delivery vehicle for therapeutic compounds, such as nanoformulations, small interfering RNA (siRNA), and miRNAs [185]. For the early diagnosis of AD, Saman et al. utilized tau-containing exosomes generated from CSF [186]. Because $A \beta$ and p-tau are both found in CSF-derived exosomes [187,188], CSF-derived exosomes may serve as a potentially helpful marker for the early diagnosis of AD [105]. Using combined markers (CSF p-tau and A) to diagnose AD, Clark et al. reported an $86 \%$ improvement in both sensitivity and specificity [189]. Additionally, exosome miRNA expression profile analysis can provide reasonably accurate insights into the etiology of AD patients. Several investigations have used exosomal miRNAs from various bodily fluids, including plasma and CSF, as biomarkers for AD [190].

By both direct and indirect routes, the intracerebral injection of BMSC EVs into the neocortex of the APPswe/PS1dE9 mouse model of AD reduces A $\beta$ levels, plaque burden, and the number of dystrophic neurites in both the hippocampus and cortex. MSC EVs interact with $A \beta$ plaques through lipid membranes, enhancing plaque phagocytosis by microglial cells to reduce plaques through the direct method. MSC EVs also contain 
neprilysin, a protease that degrades $A \beta$ plaques, decreasing intracellular $A \beta$ deposits indirectly [191]. Another study found that MSC exosomes had comparable impacts to those observed for MSCs in triggering neurogenesis and recovering cognitive functions in a rat model of AD [192].

A recent study reported by $\mathrm{Li}$ et al. offered information regarding the ability of NSC EVs to improve cognitive impairments in APP/PS1 AD model mice. The study's main findings indicated that mitochondrial function-related factors, such as sirtuin 1 (SIRT1) and synaptic proteins, were overexpressed. By contrast, oxidative damage indicators, inflammatory cytokines, and microglial markers were dramatically reduced compared with the control group [193].

Another study employed exosomes generated from NSCs subjected to heat shock to treat a mouse model of $\mathrm{AD}$, which successfully reversed cognitive impairments and improved motor performance [194]. Although MSC EVs have been used to treat AD in most studies, to date, two recent studies showed that EVs from different SC sources also have the therapeutic potential to improve $A D$-induced cognitive dysfunction via various mechanisms, such as reducing intracellular and extracellular $A \beta$ oligomer deposition. Clinical trials of SC therapy for the management of AD are shown in Table 1. 
Table 1. Clinical trials of stem cell therapy for the management of Alzheimer's disease.

\begin{tabular}{|c|c|c|c|c|c|c|c|c|}
\hline $\begin{array}{l}\text { Intervention } \\
\text { Model }\end{array}$ & $\begin{array}{c}\text { Route of } \\
\text { Administration }\end{array}$ & Cell Source & Disease Condition & $\begin{array}{l}\text { Number of } \\
\text { Patients }\end{array}$ & $\begin{array}{c}\text { Clinical Trial } \\
\text { Phase }\end{array}$ & Primary Outcome & $\begin{array}{l}\text { Clinical Trial } \\
\text { Identifier }\end{array}$ & References \\
\hline $\begin{array}{l}\text { Single group } \\
\text { assignment }\end{array}$ & Intravenous & $\begin{array}{l}\text { Human umbilical } \\
\text { cord blood-derived } \\
\text { mesenchymal stem } \\
\text { cell (MSC) }\end{array}$ & $\begin{array}{c}\text { Dementia of the Alzheimer's } \\
\text { disease (AD) type }\end{array}$ & 9 & Phase I & $\begin{array}{l}\text { Number of } \\
\text { participants with } \\
\text { adverse event }\end{array}$ & NCT01297218 & [195] \\
\hline $\begin{array}{l}\text { Single group } \\
\text { assignment }\end{array}$ & Intravenous & $\begin{array}{l}\text { Human umbilical cord } \\
\text { blood-derived MSC }\end{array}$ & $\mathrm{AD}$ & 30 & Phase I/II & $\begin{array}{c}\text { Number of } \\
\text { participants with } \\
\text { adverse event }\end{array}$ & NCT01547689 & [195] \\
\hline $\begin{array}{l}\text { Crossover } \\
\text { assignment }\end{array}$ & Subcutaneous & Filgrastim & $\mathrm{AD}$ & 8 & Phase I/II & $\begin{array}{c}\text { Change in } \\
\text { ADAS-Cog and } \\
\text { Selected } \\
\text { CANTABS tests }\end{array}$ & NCT01617577 & [196] \\
\hline Case-Control & Brain surgery & $\begin{array}{l}\text { Human umbilical cord } \\
\text { blood-derived MSC }\end{array}$ & $\begin{array}{c}\text { AD, } \\
\text { Dementia, } \\
\text { Brain diseases, } \\
\text { Central nervous system } \\
\text { diseases, } \\
\text { Nervous system diseases, } \\
\text { Tauopathies, } \\
\text { Neurodegenerative Diseases, } \\
\text { Delirium, Dementia, } \\
\text { Amnestic, Cognitive } \\
\text { Disorders, } \\
\text { Mental disorders }\end{array}$ & 14 & Phase I & $\begin{array}{l}\text { Incidence rate of } \\
\text { adverse events }\end{array}$ & NCT01696591 & [197] \\
\hline $\begin{array}{c}\text { Parallel } \\
\text { assignment }\end{array}$ & Intraventricular & $\begin{array}{l}\text { Human umbilical cord } \\
\text { blood-derived MSC }\end{array}$ & $\mathrm{AD}$ & 45 & Phase I/II & $\begin{array}{c}\text { Number of } \\
\text { subjects with } \\
\text { adverse events }\end{array}$ & NCT02054208 & [198] \\
\hline $\begin{array}{c}\text { Parallel } \\
\text { assignment }\end{array}$ & $\begin{array}{c}\text { Peripheral } \\
\text { intravenous }\end{array}$ & Longeveron MSC & $\mathrm{AD}$ & 33 & Phase I & $\begin{array}{c}\text { Incidence of } \\
\text { treatment- } \\
\text { emergent serious } \\
\text { adverse events }\end{array}$ & NCT02600130 & [199] \\
\hline
\end{tabular}


Table 1. Cont.

\begin{tabular}{|c|c|c|c|c|c|c|c|c|}
\hline $\begin{array}{l}\text { Intervention } \\
\text { Model }\end{array}$ & $\begin{array}{c}\text { Route of } \\
\text { Administration }\end{array}$ & Cell Source & Disease Condition & $\begin{array}{c}\text { Number of } \\
\text { Patients }\end{array}$ & $\begin{array}{l}\text { Clinical Trial } \\
\text { Phase }\end{array}$ & Primary Outcome & $\begin{array}{l}\text { Clinical Trial } \\
\text { Identifier }\end{array}$ & References \\
\hline $\begin{array}{c}\text { Parallel } \\
\text { assignment }\end{array}$ & Intravenous & $\begin{array}{l}\text { Human umbilical cord } \\
\text { blood-derived MSC }\end{array}$ & $\mathrm{AD}$ & 16 & Phase I/II & $\begin{array}{c}\text { Change in } \\
\text { ADAS-Cog score }\end{array}$ & NCT02672306 & [200] \\
\hline $\begin{array}{c}\text { Parallel } \\
\text { assignment }\end{array}$ & $\begin{array}{l}\text { Peripheral } \\
\text { intravenous }\end{array}$ & $\begin{array}{c}\text { Longeveron } \\
\text { allogeneic human } \\
\text { MSC }\end{array}$ & $\mathrm{AD}$ & 33 & Phase I & $\begin{array}{c}\text { Incidence of } \\
\text { treatment- } \\
\text { emergent serious } \\
\text { adverse events }\end{array}$ & NCT02600130 & [199] \\
\hline $\begin{array}{c}\text { Parallel } \\
\text { assignment }\end{array}$ & $\begin{array}{l}\text { Peripheral } \\
\text { intravenous }\end{array}$ & $\begin{array}{c}\text { Autologous bone } \\
\text { marrow-derived stem } \\
\text { cells }\end{array}$ & $\begin{array}{c}\text { AD, } \\
\text { Vascular dementia, } \\
\text { Lewy body disease, } \\
\text { Lewy body dementia with } \\
\text { behavioral disturbance, } \\
\text { Mixed dementia, } \\
\text { Parkinson-dementia } \\
\text { syndrome, } \\
\text { Chronic traumatic } \\
\text { encephalopathy, } \\
\text { Huntington's dementia, } \\
\text { Wernicke Korsakoff } \\
\text { syndrome, } \\
\text { Traumatic brain injury, } \\
\text { Multi-Infarct dementia, } \\
\text { Autism, } \\
\text { Autism spectrum disorder } \\
\text { Autistic behavior, } \\
\text { Autistic disorder, } \\
\text { Cadasil, } \\
\text { LATE limbic-predominant } \\
\text { age-related TDP-43 } \\
\text { encephalopathy }\end{array}$ & 100 & $\begin{array}{c}\text { Not } \\
\text { Applicable }\end{array}$ & Running & NCT03724136 & [202] \\
\hline
\end{tabular}




\subsection{Stem Cells for Treating ALS: Current Developments}

ALS is a neurodegenerative disorder marked by severe motor neuron degeneration, resulting in symptoms that include muscle degeneration, weakness, fasciculation, and spasticity [203]. ALS is the world's most prevalent motor neuron degenerative disease, with a national incidence and frequency of 2-3 per 100,000 and 4-66 per 100,000 [204], respectively, resulting in a high burden for both stakeholders and society. Patients tend to die within 3 to 5 years of disease onset due to gradual motor neuron loss and skeletal muscle weakness, especially the muscles responsible for respiration, leading to ALS-induced mortality [205]. A promising alternative cure for ALS is SC therapy, given the exceptional plasticity and ability of SCs to differentiate into various neuronal lineages [206]. Consequently, SCs represent a valuable source of cellular replacement. When transplanted locally or systemically, stem cells can migrate to disease-related loci to exert therapeutic effects [207]. Several stem cells can be used to alter the disease pathophysiology in modern cell therapies [208], including slowing or halting disease progression, likely by supplying surrounding cells with defensive factors [209-214].

\subsection{Encapsulation of hPSC-Derived Pancreatic Progeny for Cell Therapy}

The creation of pancreatic beta cells from human pluripotent stem cells (hPSCs) represents a promising cell replacement therapy for diabetes. The status of the actin cytoskeleton and the pancreatic transcription factors that drive pancreatic origins were established in this study. According to both bulk and single-cell RNA sequencing, various degrees of actin polymerization biased cells against endodermal differentiation pathways, and neurogenic 3-induced endocrine differentiation was substantially limited by circumstances favoring a polymerized cytoskeleton. Latrunculin A was applied to depolymerize the cytoskeleton during endocrine induction, resulting in a spatial differentiation technique to produce hPSC-derived cells with increased in vitro and in vivo mobility. SCs were trained to secrete insulin in response to glucose signaling after being separated from four hPSC lines. The transplantation of islet-sized cell aggregates successfully and rapidly corrected severe pre-existing diabetes in mice. Treated mice maintained normoglycemia for at least nine months, similar to the rate observed for human islets. hPSCs represent a powerful tool for treating illnesses at the cellular level $[30,215]$. The differentiation of pancreatic progenitors or pancreatic beta cells derived from hPSCs requires an acceptable transplant site and a suitable encapsulation material or system. The pancreas offers an acceptable microenvironment for islet maturation, but the means for delivering and retrieving these hPSCs remains limited [216].

\subsection{Immune Inflection and Suicide Gene Approach for Improving the Safety of Beta Cell Therapy}

Diabetes mellitus occurs due to the failure or dysfunction of insulin-secreting beta cells in the pancreas. Diabetes can be classified as type 1 or type 2 . Type 1 diabetes is determined by the loss of beta cells, whereas type 2 diabetes involves the development of insulin resistance, characterized by beta-cell dysfunction, in response to a mixture of hereditary and environmental factors [216]. hPSCs are a potent tool for cell therapy in both forms of diabetes.

Two types of hPSCs can be utilized: embryonic stem cells (hESCs), which are obtained from the inner mass of a developing embryo, and induced hPSCs (hiPSCs), derived through the reprogramming of somatic cells. In vitro, hPSCs can be engineered to include a final initiation point for the differentiation of beta cells and can be transformed into any cell type using the proper signaling molecules [30,215]. However, stepwise differentiation protocols were designed to direct cells toward the differentiation of pancreatic progenitor cells to generate mono-hormonal insulin-secreting cells within the body [217]. Although great advancements in encapsulation technology have been made, challenges remain when attempting to engraft transplanted cells. The elimination of the encapsulation system would expose the graft to immune system degradation. hPSCs, however, offer a powerful 
genome-editing tool that allows for the deletion of human leukocyte antigens (HLAs) that induce an immune response, allowing for the production of universal hPSC donor lines.

Interestingly, although pancreatic progenitors derived from hPSCs exhibit low levels of HLAs, HLA expression was upregulated in beta cells during in vivo maturation [218]. Islet cells demonstrate heterogeneity during development, which may indicate the presence of multiple populations of pancreatic progenitors. Due to islet architecture and beta-cell plasticity changes, heterogeneity may also develop postnatally [219].

\subsection{Strategies to Enhance Cell Survival after Transplantation: Genetic Modification and Hypoxic Preconditioning}

The survival of the transplanted cells will significantly increase the therapeutic efficacy of transplantations. Therefore, designing a plan for the primary outcome in the treatment of damaged tissues can assist in the avoidance of apoptotic cell death [220]. The ischemic myocardium must be placed in a hostile environment for transplanted cells to survive. Various treatment methods have been proposed to address the risks associated with apoptotic cell death. Exposure to transient hypoxia or anoxia can pre-condition cells, resulting in less-than-desirable effects and rendering them vulnerable to subsequent lethal ischemic injury [221]. Therapeutic transgenic delivery to the heart, either through direct injection or the engraftment of the genetically engineered donor SCs expressing the transgene-encoding vector, has yielded promising outcomes [222-224]. In tandem with cell transplantation, the transmission of growth factor genes to the heart has produced encouraging results by supporting donor cell survival [225]. A vital initiator of the apoptotic cascade is the lack of matrix conformity. For intramyocardial transmission, the suspension of donor cells in fibrin glue can significantly increase their retention in the infarcted heart, and fibrin also improves cell graft survival by supplying an unstable extracellular matrix to support the transplanted cells following intramyocardial injection [226]. Alternatively, fibrin glue injections into the ischemic myocardium can induce neovascularization, improving geographic blood flow and providing improvements in cell oxygenation. Similarly, collagen, which is a standard extracellular matrix component, has been shown to promote cell survival and growth both in vitro and in vivo, following transplantation into ischemic hearts, contributing to the improvement of left ventricle contractile function [227].

\subsection{Transplanted Neural Stem Cell Therapy for Brain Ischemic Stroke}

Ischemic stroke represents a common cause of death and injury, with no available treatments. SC transplantation represents a potential therapeutic avenue, as stroke causes irreversible neuron damage and neural tissue injury. NSCs are unique SCs that only form in the CNS and can differentiate into neurons, astrocytes, and oligodendrocytes, which can compensate for deficiencies in endogenous neurons and enhance cell survival in the inflammatory microenvironment.

Globally, stroke represents one of the top three causes of death and injury and can be classified into two types: ischemic stroke and hemorrhagic stroke, which accounts for more than three-quarters of all stroke events (approximately 80-85\%) [228]. However, the treatment of ischemic stroke must be individualized and includes heterogeneous therapies, many of which are closely associated with the location of the ischemic injury, patient age, and the capacity for neuronal self-repair. The critical goal of therapeutic stroke care is the restoration of regional cerebral blood perfusion as rapidly as possible following stroke diagnosis to prevent the incidence and degree of impaired dysfunction $[229,230]$. Exogenous NSC transplantation therapies are still far from acceptable for clinical applications due to myriad legal, therapeutic efficacy, and safety issues that remain to be resolved. Currently, few human trials have been completed, although several preclinical animal experiments have been performed [231-235]. Many preclinical animal studies of ischemic stroke have examined the therapeutic effectiveness and protective capabilities of transplanted exogenous NSCs. Their findings have revealed that exogenous NSCs can substantially enhance the prognosis of animal models of ischemic stroke; not only were clinical outcomes im- 
proved, but the histological assessment of the infarcted area showed a significant decrease, without apparent safety concerns. Two critical pathways have been identified to describe the treatment effects of exogenous NSCs for ischemic stroke [236-240].

miRNAs are involved in cellular and molecular processes, including cellular senescence, telomere length, and circadian rhythms, and can effectively be transferred into SCs. EVs harvested from cells targeted by miRNAs often contain an abundance of miRNAs, which can be applied to the treatment of age-related diseases, including stroke and AD [241]. Exosomes extracted from angiotensin-converting enzyme 2-expressing human placental MSCs improved post-stroke outcomes in an acute ischemic stroke model, according to Barzegar et al. (2020). In addition to neurological recovery, these exosomes displayed protective effects against the negative consequences of ischemic stroke [242].

Similarly, a preclinical study in animals found that nano-sized EVs derived from BMSCs encouraged neurological recovery by decreasing leukocyte infiltration in the brain, resulting in ischemic neuroprotection and reducing neurological deficits [243]. MSC EVs demonstrated therapeutic potential in a rat stroke model examined by Moon et al. They discovered that exosomal cargo, such as miRNA-184 and miRNA-210, mediated the effects of MSC EVs in the induction of neurogenesis and angiogenesis [244].

In in vitro and in vivo models of ischemic stroke, Sun et al. investigated the antiischemic effects of exosomes derived from two types of SCs, NSCs and hiPSC-derived cardiomyocytes. In vitro ischemic damage was induced by oxygen-glucose deprivation (OGD) in primary mouse astrocytic or neuronal cells, followed by exosomal treatment. In OGD-exposed astrocytes, NSC-derived exosomes provided substantial protection [245]. Overall, these findings demonstrate that SC-derived exosomes obtained from a cell-free therapeutic approach could be used to treat stroke-related damage. An analysis of cell transplantation for treating both ischemic and hemorrhage stroke models is shown in Table 2. 
Table 2. Cell transplantation medical care analysis in ischemic and hemorrhage stroke models [246].

\begin{tabular}{|c|c|c|c|c|c|c|}
\hline Administration Route & Initiation Time Point & Cell Type/Dose & Species/Model & Outcome & Mechanism & References \\
\hline \multirow[t]{8}{*}{ Intracerebral } & One month & NT2N line $/ 0.8 \mathrm{~m}$ & Rat/tMCAO & Motor purpose retrieval & $\begin{array}{l}\text { Biobridge, cell standby, persuaded } \\
\text { evolution, and trophic provision }\end{array}$ & {$[247,248]$} \\
\hline & Seven days & hBMSC & Rat/tMCAO & Sensorimotor salvage & Tempted progress and trophic backing & {$[249,250]$} \\
\hline & Fourteen days & MHP36 line $/ 0.2 \mathrm{~m} / 8 \mu \mathrm{L}$ & Rat/tMCAO & Sensorimotor recapture & Cubicle additional & {$[251,252]$} \\
\hline & Seven days & hBMSC & Rat/ICH & $\begin{array}{l}\text { Sensorimotor } \\
\text { repossession }\end{array}$ & Made increase and trophic issues & [253] \\
\hline & Seven days & hNSC/ & Mouse/ICH & Motor role regaining & Cell spare & [254] \\
\hline & Seven days & $\mathrm{hNSC} / 0.8 \mathrm{~m} / 2 \mu \mathrm{L}$ & Rat/Endothelin & Motor role regaining & Cell auxiliary & [255] \\
\hline & Seven days & $\mathrm{hES} / 0.2 \mathrm{~m} / 4 \mu \mathrm{L}$ & $\begin{array}{l}\text { Stroke Mouse/Barrel } \\
\text { Stroke }\end{array}$ & $\begin{array}{l}\text { Sensorimotor } \\
\text { recuperation }\end{array}$ & Cell additional & [256] \\
\hline & Seven days & $\mathrm{rESC} / 0.1 \mathrm{~m}$ & Rat/MCAO & $\begin{array}{l}\text { Endurance and diversity } \\
\text { of implants }\end{array}$ & Cell renewal & [257] \\
\hline Intracranial & Seven days & $\mathrm{miPS} / 0.4 \mathrm{~m} / 4 \mu \mathrm{L}$ & Rat/Barrel Stroke & Sensorimotor retaking & Cell replacing & [258] \\
\hline \multirow[t]{5}{*}{ Intravenous } & & $\mathrm{rBMSC} / 1 \mathrm{~m} / 1 \mathrm{~mL}$ & Rat/tMCAO & $\begin{array}{l}\text { Dipping alteration, } \\
\text { motor recouping }\end{array}$ & Hinder endothelial disfunction & [259] \\
\hline & Twenty-four hours & hUCBC & Rat/tMCAO & Sensorimotor replevin & Cell substitution & [260] \\
\hline & Twenty-four hours & $\mathrm{rMSC} / 3 \mathrm{~m}$ & Rat/tMCAO & $\begin{array}{l}\text { Sensorimotor } \\
\text { reclamation }\end{array}$ & Red-reducing cell death & [261] \\
\hline & - & hNSC & Rat & $\begin{array}{l}\text { Sensorimotor } \\
\text { recovery }\end{array}$ & Cell replacement & [262] \\
\hline & & $\mathrm{hNSC} / 5 \mathrm{~m} / 500 \mu \mathrm{L}$ & Rat/ICH & & & \\
\hline \multirow[t]{2}{*}{ Intra-arterial } & One hour & $\mathrm{rBMSC} / 1 \mathrm{~m} / 1 \mathrm{~mL}$ & Rat/tMCAO & $\begin{array}{l}\text { Relying reducing } \\
\text { infarction }\end{array}$ & Induced growth and trophic item & [263] \\
\hline & Twenty-four hours & hBMSC /1000 & & Sensorimotor recapture & Decreasing swelling & [264] \\
\hline Intranasal & Six hours & $\mathrm{rBMSC} / 1 \mathrm{~m} / 100 \mu \mathrm{L}$ & Rat/Barrel Stroke & $\begin{array}{l}\text { Dipping infarction, } \\
\text { sensorimotor recovery, } \\
\text { better-quality olfactive } \\
\text { roles, and } \\
\text { neuropsychiatric aids }\end{array}$ & Prompt germination and trophic factors & [265] \\
\hline
\end{tabular}




\subsection{Stem Cell Transplantation in Stroke Clinical Trials}

Individual experiments exploring the efficacy of SC transplantations in the treatment of stroke are ongoing. Recent research confirmed that human neuronal cells successfully engrafted onto the stroke-damaged brain region survive for up to 2 years after the initial engraftment in a single patient [266]. Other cell transplantation studies in patients with PD have noted the survival of engrafted cells for up to 14 years after transplantation [267].

SC transplantation requires additional research prior to translation into real-world clinical applications. The development of SC-based paradigms for stroke treatments requires that experts, clinicians, managers, and industry delegates establish guidelines through preclinical and clinical assessments. A set of basic guidelines for SC-based research were established in 2009 [268], followed by an update in early 2011 [269]. An analysis of existing stem cells research for stroke treatment enhances the likelihood that a therapeutic strategy will emerge for clinical translation [270]. The clinical trials in case of stroke by using stem cell therapy is shown in Table 3. 
Table 3. Stroke clinical trials using stem cell therapy [246].

\begin{tabular}{|c|c|c|c|c|c|c|}
\hline Trails & $\begin{array}{c}\text { Initiation } \\
\text { Year and Country }\end{array}$ & $\begin{array}{c}\text { Cell } \\
\text { Source and Administration } \\
\text { Route }\end{array}$ & Population & Outcome & Status & References \\
\hline \multirow[t]{11}{*}{ Safety } & - & NT2/D1 and Intracerebral & $\begin{array}{l}\text { Basal ganglia } \\
\text { stroke }\end{array}$ & Feasible & Completed & {$[266,271]$} \\
\hline & 2001, USA & NT2/D1 and Intracerebral & Stroke patients & $\begin{array}{l}\text { Feasible with small } \\
\text { risk of seizure }\end{array}$ & Completed & [272] \\
\hline & - & MSC and Intravenous & MCA & - & - & [273] \\
\hline & 2008, India & BMMNC and Intrathecal & Stroke patients & - & Completed & [275] \\
\hline & 2009, Cuba & BMSC and Intracerebral & Stroke patients & $\begin{array}{c}\text { Good tolerance and } \\
\text { safety }\end{array}$ & Completed & [276] \\
\hline & 2010, Brazil & BMMNC and Intra-arterial & $\begin{array}{c}\text { Nonacute } \\
\text { ischemic stroke }\end{array}$ & Feasible and safe & Completed & [277] \\
\hline & 2011, Japan & MSC and Intravenous & Stroke patients & Feasible and safe & Completed & [278] \\
\hline & 2012, Brazil & BMMNC and Intra-arterial & $\begin{array}{c}\text { MCA acute } \\
\text { ischemic stroke }\end{array}$ & Safe & Completed & [280] \\
\hline & 2010, UK & NSC and Intracranial & Stroke patients & & Ongoing & [231] \\
\hline & 2011, Taiwan & OEC and Intracerebral & $\begin{array}{c}\text { Thromboembolic } \\
\text { Stroke }\end{array}$ & - & - & [281] \\
\hline & 2012, China & HSC and Intra-arterial & $\begin{array}{l}\text { Internal carotid } \\
\text { artery territory } \\
\text { infarction }\end{array}$ & $\mathrm{N} / \mathrm{A}$ & Recruiting & [282] \\
\hline
\end{tabular}


Table 3. Cont.

\begin{tabular}{|c|c|c|c|c|c|c|}
\hline Trails & $\begin{array}{l}\text { Initiation } \\
\text { Year and Country }\end{array}$ & $\begin{array}{c}\text { Cell } \\
\text { Source and Administration } \\
\text { Route }\end{array}$ & Population & Outcome & Status & References \\
\hline & 2014, Spain & $\begin{array}{c}\mathrm{BMMNC} / 2 \mathrm{~m} / \mathrm{kg} \\
\text { or } 5 \mathrm{~m} / \mathrm{kg} \text { and Intra-arterial }\end{array}$ & $\begin{array}{c}\text { Moderate-to-severe acute } \\
\text { ischemic stroke } \\
\text { patients }\end{array}$ & $\begin{array}{l}\text { Appears to be safe; } \\
30 \% \text { clinical } \\
\text { improvement at } 90 \\
\text { days }\end{array}$ & Recruiting & [283] \\
\hline & 2014, China & NSC and Intracerebral & $\begin{array}{c}\text { Chronic } \\
\text { ischemia stroke }\end{array}$ & - & Completed & [284] \\
\hline & 2014, China & EPC and Intravenous & $\begin{array}{c}\text { Chronic } \\
\text { ischemia stroke }\end{array}$ & - & Recruiting & [285] \\
\hline & 2015, China & UCMSC $/ 20 \mathrm{~m}$ and Intravenous & $\mathrm{ICH}$ & - & Ongoing & [286] \\
\hline & 2016, China & UCMSC and Intravenous & $\begin{array}{c}\text { Intracerebral } \\
\text { ischemic stroke }\end{array}$ & - & - & [287] \\
\hline & 2016, Taiwan & ADSC and Intracerebral & Stroke patients & - & - & $\begin{array}{c}\text { NCT02813512 } \\
\text { [288] }\end{array}$ \\
\hline \multirow{4}{*}{ Efficacy } & 2009, Taiwan & CD34+ Stem Cell and Intracerebral & $\begin{array}{l}\text { Chronic stroke } \\
\text { adult patient }\end{array}$ & - & Completed & [290] \\
\hline & 2011, USA & $\begin{array}{c}\text { BMSC } / 2.5 \mathrm{~m} \\
5.0 \mathrm{~m} \text { or } 10 \mathrm{~m} \text { and Intracranial }\end{array}$ & $\begin{array}{l}\text { Chronic stroke } \\
\text { patients }\end{array}$ & $\begin{array}{l}\text { No serious adverse } \\
\text { events attributable } \\
\text { and significant } \\
\text { improvements in motor } \\
\text { impairment }\end{array}$ & Completed & [291] \\
\hline & 2014, UK & NSC and Intracerebral & $\begin{array}{c}\text { Stroke } \\
\text { patient Phase II }\end{array}$ & $\begin{array}{l}\text { Strongly positive } \\
\text { results for } 12 \text { months; } \\
\text { Well-tolerated/no } \\
\text { serious adverse } \\
\text { events }\end{array}$ & Ongoing & [292] \\
\hline & 2014, India & BMMNC and Intravenous & $\begin{array}{l}\text { Ischemic stroke } \\
\text { Phase II }\end{array}$ & $\begin{array}{c}\text { Safe but no beneficial } \\
\text { effect }\end{array}$ & Recruiting & [293] \\
\hline
\end{tabular}


Table 3. Cont.

\begin{tabular}{|c|c|c|c|c|c|c|}
\hline Trails & $\begin{array}{l}\text { Initiation } \\
\text { Year and Country }\end{array}$ & $\begin{array}{c}\text { Cell } \\
\text { Source and Administration } \\
\text { Route }\end{array}$ & Population & Outcome & Status & References \\
\hline & 2016, US/UK & Multi stem cells and Intravenous & $\begin{array}{c}\text { Ischemic stroke } \\
\text { Phase II }\end{array}$ & $\begin{array}{l}\text { Excellent; 12-month } \\
\text { functional } \\
\text { improvement }\end{array}$ & Completed & [294] \\
\hline & 2016, Europe & $\mathrm{ADSC} / 1 \mathrm{~m} / \mathrm{kg}$ and Intravenous & $\begin{array}{l}\text { Hemispheric } \\
\text { ischemic stroke }\end{array}$ & - & Recruiting & [281] \\
\hline
\end{tabular}

This list is not an exhaustive collection of all ongoing clinical trials, but it includes a sample of available studies from published papers, searchable websites, and ClinicalTrials.gov Identifiers. 
5.9. Extracellular Vesicles Derived from Mesenchymal Stem Cells Protect against Neonatal Stroke by Interacting with Microglial Cells

MSC EVs are derived from BMSCs and can be characterized according to their size distribution (NanoSightTM), and their MSC origins and localization were confirmed by identifying protein markers. The damaged and contralateral cortices of postnatal day 9 (P9) mice were extracted and cultured after a 3-h transient middle cerebral artery occlusion (tMCAO). MSC EV treatment reduced the injury volume $72 \mathrm{~h}$ after $\mathrm{tMCAO}$, in part via modulatory effects on microglial cells. MSC EVs were primarily detected in $\mathrm{Iba}^{+}$cells and $\mathrm{GLUT1}^{+}$blood vessels in the ischemic-reperfusion area after $72 \mathrm{~h} \mathrm{[296].}$

\section{Neuro-protective Role of SCs in Neuroinflammation}

Neurological problems disturb the brain's and spinal cord's normal function and are a leading cause of mortality and disability globally. Speech, memory, sensorimotor, and autonomic functions are all affected by central nervous system dysfunction, which can have a significant impact on a patient's quality of life. The neuro-protective role of SCs in neuroinflammation are shown in Table 4. 
Table 4. Significant neuroinflammatory mediators [297]

\begin{tabular}{|c|c|c|c|c|c|}
\hline & Family & Types & Produced By & Role & References \\
\hline \multirow{4}{*}{ Cytokines } & $\begin{array}{l}\text { Pleiotropic polypeptides } \\
\text { (glycoproteins) }\end{array}$ & $\begin{array}{l}\text { Tumor necrosis factor- } \alpha \text { (TNF- } \alpha) \text {, } \\
\text { IL-1 } \beta \text {, IL-6, IL-20, IL-10, and } \\
\text { transforming growth factor } \\
\text { (TGF)- } \beta\end{array}$ & Microglia & $\begin{array}{c}\text { Neuroinflammation (TNF- } \alpha \text {, } \\
\text { IL-1 } \beta, \text { IL-6, IL-20) }\end{array}$ & \multirow{4}{*}[298,299]{} \\
\hline & & & Astrocytes & $\begin{array}{c}\text { Neuroprotection (IL-10 and } \\
\text { TGF- } \beta \text { ) }\end{array}$ & \\
\hline & & & $\begin{array}{l}\text { Neurons and Endothelial } \\
\text { cells }\end{array}$ & & \\
\hline & & & Invading leukocytes & & \\
\hline \multirow[t]{3}{*}{ Chemokines } & $\begin{array}{c}\text { Small cytokines (classified } \\
\text { into subgroups according to } \\
\text { variations in cysteine } \\
\text { residues) }\end{array}$ & $\begin{array}{c}\text { Monocyte chemoattractant protein } \\
1 \text { (MCP-1), macrophage } \\
\text { inflammatory protein- } 1 \alpha(\text { MIP- } 1 \alpha), \\
\text { and fractalkine }\end{array}$ & Microglia & $\begin{array}{l}\text { Pro-inflammatory as } \\
\text { chemoattractants for } \\
\text { invading leukocytes }\end{array}$ & \multirow[t]{3}{*}{ [300] } \\
\hline & & & Astrocytes & & \\
\hline & & & Injured neurons & & \\
\hline \multirow{2}{*}{$\begin{array}{l}\text { Cellular adhesion molecules } \\
\text { (CAMs) }\end{array}$} & & & Epithelial cells & & \multirow{2}{*}{ [301] } \\
\hline & & & Leukocytes & & \\
\hline \multirow[t]{2}{*}{ Reactive oxygen species } & Free oxygen radicals & $\begin{array}{l}\text { Superoxide anion radical }\left(\mathrm{O}_{2} \bullet-\right) \\
\text { singlet oxygen }\left({ }^{1} \mathrm{O}_{2}\right) \text {, hydroxyl } \\
\text { radical }(\cdot \mathrm{OH}) \text { and perhydroxyl } \\
\text { radical }\left(\mathrm{HO}_{2} \cdot\right) \text {, nitric oxide }(\mathrm{NO})\end{array}$ & $\begin{array}{c}\text { Neuronal, endothelial* and } \\
\text { inducible NO synthases (n-, } \\
\text { e-, iNOS, respectively), } \\
\text { Oxidative imbalance }\end{array}$ & Ischemic cell death & \multirow[t]{2}{*}{ [302] } \\
\hline & & & & $\begin{array}{c}\text { Endothelial NO production } \\
\text { can have a } \\
\text { neuroprotective effect }\end{array}$ & \\
\hline
\end{tabular}


Table 4. Cont.

\begin{tabular}{|c|c|c|c|c|c|}
\hline & Family & Types & Produced By & Role & References \\
\hline \multirow[t]{3}{*}{ Matrix metalloproteases } & $\begin{array}{l}\text { Zinc-containing } \\
\text { endopeptidases }\end{array}$ & $\begin{array}{l}\text { MMP-2 (gelatinase A) and MMP-9 } \\
\text { (gelatinase-B) }\end{array}$ & Endothelial cells & $\begin{array}{l}\text { Pro-inflammatory via } \\
\text { degradation of BBB to } \\
\text { facilitate invasion of } \\
\text { peripheral leukocytes }\end{array}$ & \multirow[t]{3}{*}{ [303] } \\
\hline & & & Neutrophils & & \\
\hline & & & Macrophages & & \\
\hline \multirow{2}{*}{ Regulatory T cells } & Lymphocytes & $\mathrm{CD} 4^{+} \mathrm{CD} 25^{+}$ & $\begin{array}{l}\text { Dendritic or } \\
\text { antigen-presenting cell }\end{array}$ & Immunosuppressive & \multirow{2}{*}{ [304] } \\
\hline & & & & $\begin{array}{c}\text { Mediate mi- } \\
\text { croglial/astrocytic activation }\end{array}$ & \\
\hline
\end{tabular}


The success of cell transplantation and its efficacy to treat neuroinflammation is determined by several parameters, including the route, dosage, and time of administration, but the cell type used is the most essential [305].

Importantly, stem cell therapy offers a treatment paradigm that is especially suited to combating both acute and chronic inflammatory conditions. Researchers have long emphasized the need for neuroprotection during the subacute period of stroke and other bran injuries because inflammation often occurs during this period and, if left untreated, can greatly aggravate the extent of injury [306]. Both the subacute and chronic stages of neuroinflammation require neuro-regeneration and the maintenance of anti-inflammatory activities [307,308]. Chronic stem cell therapy is intended to activate brain rejuvenation and reperfusion by stimulating regenerative mechanisms such as vasculogenesis, neurogenesis, angiogenesis, and synaptogenesis [309]. It can restore cerebral infrastructure, such as the BBB, and sequester inflammatory insults, such as oxidative stress and mitochondrial impairment [310,311].

Stem cell therapy has the potential to address an alarmingly gloomy vacuum in known subacute and chronic treatments for neuroinflammatory patients by supporting the damaged brain in healing from an ischemic or hemorrhagic event by moderating endogenous neuroinflammation [312] and stimulating reinnervation [313]. Fetal cells, NT2N cells, CTX0E3, embryonic stem cells, neural stem/progenitor cells, umbilical cord blood, amnion, adipose, and induced pluripotent stem cells have been investigated in laboratory experiments over the years [314-318].

While several of these cell types have been studied in clinical trials for ischemic stroke and other neuro disorders such as AD, PK, and ALS (amyotrophic lateral sclerosis), much of the current preclinical research and clinical trials have focused on bone marrow cellular derivatives [319]. Other disease indications have shown that bone marrow-derived stem cells, such as mesenchymal stem cells (MSCs), endothelial progenitor cells (EPCs), SB623, multipotent adult progenitor cells (MAPCs), and multilineage-differentiating stress enduring (Muse) cells, have a good safety profile [320]. Furthermore, bone marrow-derived stem cells, particularly MSCs, have been widely examined in animal models.

Transplanted NSCs reduce neuroinflammation, increase neurogenesis, and restore cognitive performance in Alzheimer's disease animal models [321]. In addition, NSC implantation reduced cross-communication between NSCs and endothelial cells. As a result, NSC-based therapy for Alzheimer's disease could provide an optimal neural microenvironment to prevent neurodegeneration and ensure the survival of mature neurons [322].

MSC transplantation into AD models showed neuroprotective potential via modifying neuroinflammation, promoting endogenous hippocampus neurogenesis, reducing neuro apoptosis, and enhancing the signaling pathway. Transplantation of bone marrow-derived MSCs (BM-MSCs) into mouse AD models, for example, reduces neuroinflammation and improves neuropathology and cognition [323,324].

A study conducted by Neelam K. Venkataramana and colleagues [325] indicated that stem cells have a beneficial effect. Seven PD patients, aged 22 to 62 years old and with a mean disease duration of 14.77 .56 years, participated in a prospective, uncontrolled pilot research of single-dose, unilateral autologous bone marrow-derived mesenchymal stem cell transplantation (BM-MSCs). After 36 months of follow-up, three of the seven patients demonstrated a significant improvement in their Unified Parkinson's Disease Rating Scale (UPDRS) score of 38 percent [326].

Stem cell therapy may be able to help people with ALS live longer. This is accomplished by stem cells' ability to specialize in specific supporting cells like astrocytes and microglia (cells within the central nervous system). These supporting cells may halt the degeneration of motor neurons in the central nervous system [327].

In animal models of neuroinflammation, laboratory evidence evaluating whether the same stem cell population is capable of both preventative/protective and restorative actions [328,329]. However, because most inflammatory episodes are unpredictable, using 
stem cells as a preventive or protective treatment in the clinic may be limited, suggesting that stem cell therapy is better suited as a regenerative biologic.

\section{Discussion}

\subsection{Ethical Issues and Safety Concerns Regarding hESC-Based Therapies}

Human embryonic stem cells (hESCs) originate from the pluripotent inner cell mass of pre-implantation embryos' [330,331]. Octamer-limiting record factor 3/4 (OCT3/4), stage-unequivocal lacking antigens 3 and 4 (SSEA-3 and SSEA-4), TRA-1-60, TRA-1-81, and acid neutralizer phosphatase represent standard pluripotent SC markers, associated with enhanced levels of telomerase development and normal karyotypes. Under in vitro and in vivo conditions [332,333], hESC can develop into any of the three germ layers (endoderm, mesoderm, and ectoderm) and any cell type. With improved cell substitution techniques, hESCs hold the remarkable promise of the eventual treatment of human disease [334].

\subsection{Surgical Safety Aspects of Cell Transplantation}

The damaged spinal cord in patients with ALS can tolerate sequential microinjections delivered to the cervical and thoracolumbar spinal regions. Patients with either transcendent bulbar ALS or ongoing immunosuppression might be vulnerable to increased periprocedural risks. Regular preclinical examinations are expected to create, additionally, (1) the capacity to determine the necessity for immunosuppressant use, (2) imaging modalities equipped to distinguish post-implantation engraftment, limitations, and efficacy, and (3) improved methods for identifying allogeneic human engraftments in the spinal cord of human recipients. We have recently obtained an FDA endorsement to advance into a stage II preliminary trial, which will determine toxicity limits and determine the endurance limits of the ALS spinal cord.

Further, this study will evaluate the scope of modifiable treatment parameters that can be endured (e.g., infusion number, infusion sites, complete portion conveyed). When characterized, the resulting multicohort preliminary studies will evaluate the optimal procedure and the feasibility of this treatment approach. The ALS spinal cord may serve as an ideal setting to ascertain the resilience of the spinal cord while determining the optimal method for delivering SC-based therapeutics and evaluating the signs and symptoms that indicate successful engraftment. Long-term goals will focus on the clinical approval of a focused microinjection approach for the application of SC-based therapies to a wide range of spinal cord afflictions [335].

\subsection{Optimizing the Therapeutic Efficacy of Neural Stem Cell Transplantation}

Although preclinical studies have confirmed the efficacy and safety of NSC transplantations for treating ischemic stroke, a few points of contention remain. The engraftment and survival rate of NSCs in vivo is less than 5\%, indicating that various issues should be addressed before this methodology can be translated into clinical applications [336339]. The critical issues that must be optimized include in vivo competence and NSC differentiation following transplantation. Both endogenous and exogenous NSCs are more likely to differentiate into glial cells than neurons in vivo [340-342]. Different studies have attempted to adjust the NSC contents at the protein level through many methods, such as viral transfection, heat pre-treatment, antibody treatments, and cytokine treatments to determine whether any of these effects can shift differentiation toward neurons [343].

\section{Future Perspectives}

The health sector continues to grow effectively, developing new ideas for saving lives and making complex processes such as SC transplantation therapy, which plays a significant role in drug development and bioscience research and is likely to improve very effectively [344]. The numerous cell types and their origins that can be used in cell therapies for neurological diseases are depicted schematically in this diagram [18]. To 
be effective, SC therapy for neurological diseases must fulfill specific conditions. First, the grafted cell should differentiate into the cell type of interest, both in vivo and in vitro. Second, the grafted cells must integrate into the local neural network. Third, the half-life of the grafted cell should be extended. Fourth, and most importantly, tumor formation should not occur. Last, the pathological microenvironment of an animal model might affect the safety and efficacy of SC therapy [345]. The majority of neural autoimmune diseases are likely to benefit from the development of aHSCT. ADMSCs may cause a potent immune-suppressive effect [346]. Human ESCs can be obtained from the inner cell mass of blastocysts, and fetal brain cells can be obtained from aborted fetuses. iPSCs can be obtained by reprogramming modified cells, such as human fibroblasts, and MSCs can be obtained from cord blood or bone marrow. These unique cell types can be developed into neuronal prototypes and implanted into damaged brains [347]. Moreover, transplantation with ESCs might produce a tolerant immune system that crosses HLA barriers [348]. Some critical factors that may affect the therapeutic outcomes of SC transplantation include the SC type, the administration route, the administration dose, and mechanisms of activity, all of which should be analyzed in future clinical trials [349-351]. For the future development of SC transplantation therapies, the most crucial step is to design and perform trials at experienced centers with experience in both transplantation and autoimmune diseases, and utilize new strategies and international collaborations to facilitate timely comparisons with current best standards of care in the context of well-designed, randomized clinical trials [352].

\section{Conclusions}

Based on extensive previous research, the underlying mechanisms of action that lead to the development of neurological diseases remain under investigation. The promise of SC transplantation increases daily, with excellent results reported in animal models. However, human trials must still be performed, although some small-scale experiments have been conducted, which have revealed the potential for severe side effects. The treatment of individual neurological disorders will be associated with different pathophysiological conditions; therefore, transplantation therapy must be performed under optimal conditions with minimal risk. Before performing transplantations in humans, basic research remains essential [344]. As described by Cao et al., current research offers no strong evidence or certainty that the SC process can do what it is intended to do, and it has not yet reached its expected level [353]. Determining the exact mechanisms that guide NSC differentiation can be problematic in the context of CNS injury, but choosing these pathways may be crucial to the future of successful SC-based treatment strategies for patients [353].

Author Contributions: Conceptualization, M.M.R., M.R.I., M.A. and T.B.E.; methodology, M.M.R., M.R.I., M.T.I., M.H.-O.-R., M.I. and M.B.U.; validation, S.D., M.S.R., M.A., F.A.A., T.B.E. and A.A.-R.M.; formal analysis, M.M.R., M.R.I.F., M.U.K., F.A.A., S.A., G.M.-H. and T.B.E.; investigation, M.M.R., M.T.I., M.H.-O.-R., M.I., M.B.U., S.D., M.S.R. and M.A.; resources, S.A., A.A.-R.M., M.R.I.F., M.U.K., F.A.A., G.M.-H. and T.B.E.; data curation, M.M.R., M.R.I., M.T.I. and T.B.E.; writing-original draft preparation, M.M.R., M.R.I., M.T.I., M.H.-O.-R., M.I., M.B.U., S.D., M.S.R., M.A. and T.B.E.; writingreview and editing, S.A., T.B.E., A.A.-R.M., M.R.I.F., M.U.K., F.A.A. and G.M.-H.; visualization, S.A., T.B.E., A.A.-R.M., M.R.I.F., M.U.K., F.A.A. and G.M.-H.; supervision, S.A. and T.B.E.; project administration, S.A. and T.B.E.; funding acquisition, S.A. and T.B.E. All authors have read and agreed to the published version of the manuscript.

Funding: This work was supported by the Research Universiti Grant, Universiti Kebangsaan Malaysia, Dana Impak Perdana (DIP), code: 2020-018.

Institutional Review Board Statement: Not applicable.

Informed Consent Statement: Not applicable.

Data Availability Statement: Not Applicable.

Conflicts of Interest: The authors declare no conflict of interest. 


\section{References}

1. Agrawal, M.; Biswas, A. Molecular Diagnostics of Neurodegenerative Disorders. Front. Mol. Biosci. 2015, 2, 54. [CrossRef] [PubMed]

2. Surugiu, R.; Olaru, A.; Hermann, D.M.; Glavan, D.; Catalin, B.; Popa-Wagner, A. Recent Advances in Mono- and Combined Stem Cell Therapies of Stroke in Animal Models and Humans. Int. J. Mol. Sci. 2019, 20, 6029. [CrossRef] [PubMed]

3. Lang-Lazdunski, L.; Matsushita, K.; Hirt, L.; Waeber, C.; Vonsattel, J.P.; Moskowitz, M.A.; Dietrich, W.D. Spinal Cord Ischemia. Development of a Model in the Mouse. Stroke 2000, 31, 208-213. [CrossRef] [PubMed]

4. Vasic, V.; Barth, K.; Schmidt, M.H.H. Neurodegeneration and Neuro-Regeneration-Alzheimer's Disease and Stem Cell Therapy. Int. J. Mol. Sci. 2019, 20, 4277. [CrossRef]

5. Marchetto, M.C.; Brennand, K.J.; Boyer, L.F.; Gage, F.H. Induced Pluripotent Stem Cells (IPSCs) and Neurological Disease Modeling: Progress and Promises. Hum. Mol. Genet. 2011, 20, R109-R115. [CrossRef] [PubMed]

6. Rice, C.M.; Halfpenny, C.A.; Scolding, N.J. Stem Cells for the Treatment of Neurological Disease. Transfus. Med. 2003, 13, 351-361. [CrossRef] [PubMed]

7. Des Rieux, A. Stem Cells and Their Extracellular Vesicles as Natural and Bioinspired Carriers for the Treatment of Neurological Disorders. Curr. Opin. Colloid Interface Sci. 2021, 54, 101460. [CrossRef]

8. Fu, M.-H.; Li, C.-L.; Lin, H.-L.; Chen, P.-C.; Calkins, M.J.; Chang, Y.-F.; Cheng, P.-H.; Yang, S.-H. Stem Cell Transplantation Therapy in Parkinson's Disease. SpringerPlus 2015, 4, 597. [CrossRef] [PubMed]

9. Freed, C.R.; Greene, P.E.; Breeze, R.E.; Tsai, W.Y.; DuMouchel, W.; Kao, R.; Dillon, S.; Winfield, H.; Culver, S.; Trojanowski, J.Q.; et al. Transplantation of Embryonic Dopamine Neurons for Severe Parkinson's Disease. N. Engl. J. Med. 2001, 344, 710-719. [CrossRef]

10. Farhadi, M.; Boroujeni, M.E.; Kamrava, S.K.; Bagher, Z.; Tehrani, A.M.; Aghajanpour, F.; Ezi, S.; Soltani, R.; Khatmi, A.; Alizadeh, R. Implantation of Human Olfactory Ecto-Mesenchymal Stem Cells Restores Locomotion in a Rat Model of Parkinson's Disease. J. Chem. Neuroanat. 2021, 114, 101961. [CrossRef]

11. Sharma, P.; Sharma, A.; Fayaz, F.; Wakode, S.; Pottoo, F.H. Biological Signatures of Alzheimer's Disease. Curr. Top. Med. Chem. 2020, 20, 770-781. [CrossRef]

12. Yu, D.X.; Marchetto, M.C.; Gage, F.H. Therapeutic Translation of IPSCs for Treating Neurological Disease. Cell Stem Cell 2013, 12, 678-688. [CrossRef]

13. Zhang, P.; Liu, B. Effect of Autologous Hematopoietic Stem Cell Transplantation on Multiple Sclerosis and Neuromyelitis Optica Spectrum Disorder: A PRISMA-Compliant Meta-Analysis. Bone Marrow Transplant. 2020, 55, 1928-1934. [CrossRef]

14. Noseworthy, J.H.; Lucchinetti, C.; Rodriguez, M.; Weinshenker, B.G. Multiple Sclerosis. N. Engl. J. Med. 2000, 343, 938-952. [CrossRef] [PubMed]

15. Burt, R.K.; Loh, Y.; Pearce, W.; Beohar, N.; Barr, W.G.; Craig, R.; Wen, Y.; Rapp, J.A.; Kessler, J. Clinical Applications of Blood-Derived and Marrow-Derived Stem Cells for Nonmalignant Diseases. JAMA 2008, 299, 925-936. [CrossRef] [PubMed]

16. Abrahamsson, S.V.; Angelini, D.F.; Dubinsky, A.N.; Morel, E.; Oh, U.; Jones, J.L.; Carassiti, D.; Reynolds, R.; Salvetti, M.; Calabresi, P.A.; et al. Non-Myeloablative Autologous Haematopoietic Stem Cell Transplantation Expands Regulatory Cells and Depletes IL-17 Producing Mucosal-Associated Invariant T Cells in Multiple Sclerosis. Brain J. Neurol. 2013, 136, 2888-2903. [CrossRef]

17. Muraro, P.A.; Douek, D.C.; Packer, A.; Chung, K.; Guenaga, F.J.; Cassiani-Ingoni, R.; Campbell, C.; Memon, S.; Nagle, J.W.; Hakim, F.T.; et al. Thymic Output Generates a New and Diverse TCR Repertoire after Autologous Stem Cell Transplantation in Multiple Sclerosis Patients. J. Exp. Med. 2005, 201, 805-816. [CrossRef] [PubMed]

18. Ishii, T.; Eto, K. Fetal Stem Cell Transplantation: Past, Present, and Future. World J. Stem Cells 2014, 6, 404-420. [CrossRef]

19. Lindvall, O.; Kokaia, Z. Stem Cells for the Treatment of Neurological Disorders. Nature 2006, 441, 1094-1096. [CrossRef] [PubMed]

20. Hess, D.C.; Borlongan, C.V. Stem Cells and Neurological Diseases. Cell Prolif. 2008, 41 (Suppl. 1), 94-114. [CrossRef]

21. Bjorklund, L.M.; Sánchez-Pernaute, R.; Chung, S.; Andersson, T.; Chen, I.Y.C.; McNaught, K.S.P.; Brownell, A.-L.; Jenkins, B.G.; Wahlestedt, C.; Kim, K.-S.; et al. Embryonic Stem Cells Develop into Functional Dopaminergic Neurons after Transplantation in a Parkinson Rat Model. Proc. Natl. Acad. Sci. USA 2002, 99, 2344-2349. [CrossRef]

22. Takagi, Y.; Takahashi, J.; Saiki, H.; Morizane, A.; Hayashi, T.; Kishi, Y.; Fukuda, H.; Okamoto, Y.; Koyanagi, M.; Ideguchi, M.; et al. Dopaminergic Neurons Generated from Monkey Embryonic Stem Cells Function in a Parkinson Primate Model. J. Clin. Investig. 2005, 115, 102-109. [CrossRef]

23. Ferrari, D.; Sanchez-Pernaute, R.; Lee, H.; Studer, L.; Isacson, O. Transplanted Dopamine Neurons Derived from Primate ES Cells Preferentially Innervate DARPP-32 Striatal Progenitors within the Graft. Eur. J. Neurosci. 2006, 24, 1885-1896. [CrossRef] [PubMed]

24. Liu, S.; Qu, Y.; Stewart, T.J.; Howard, M.J.; Chakrabortty, S.; Holekamp, T.F.; McDonald, J.W. Embryonic Stem Cells Differentiate into Oligodendrocytes and Myelinate in Culture and after Spinal Cord Transplantation. Proc. Natl. Acad. Sci. USA 2000, 97, 6126-6131. [CrossRef]

25. Bottai, D.; Cigognini, D.; Madaschi, L.; Adami, R.; Nicora, E.; Menarini, M.; Di Giulio, A.M.; Gorio, A. Embryonic Stem Cells Promote Motor Recovery and Affect Inflammatory Cell Infiltration in Spinal Cord Injured Mice. Exp. Neurol. 2010, 223, 452-463. [CrossRef] [PubMed] 
26. Wei, L.; Cui, L.; Snider, B.J.; Rivkin, M.; Yu, S.S.; Lee, C.-S.; Adams, L.D.; Gottlieb, D.I.; Johnson, E.M.; Yu, S.P.; et al. Transplantation of Embryonic Stem Cells Overexpressing Bcl-2 Promotes Functional Recovery after Transient Cerebral Ischemia. Neurobiol. Dis. 2005, 19, 183-193. [CrossRef] [PubMed]

27. Chang, D.J.; Lee, N.; Park, I.H.; Choi, C.; Jeon, I.; Kwon, J.; Oh, S.H.; Shin, D.A.; Do, J.T.; Lee, D.R.; et al. Therapeutic Potential of Human Induced Pluripotent Stem Cells in Experimental Stroke. Cell Transplant. 2013, 22, 1427-1440. [CrossRef] [PubMed]

28. Li, P.-J.; Jin, T.; Luo, D.-H.; Shen, T.; Mai, D.-M.; Hu, W.-H.; Mo, H.-Y. Effect of Prolonged Radiotherapy Treatment Time on Survival Outcomes after Intensity-Modulated Radiation Therapy in Nasopharyngeal Carcinoma. PLoS ONE 2015, 10, e0141332. [CrossRef]

29. Ovsiew, F. What Is Wrong in Conversion Disorder? J. Neurol. Neurosurg. Psychiatry 2003, 74, 557. [CrossRef] [PubMed]

30. Takahashi, K.; Tanabe, K.; Ohnuki, M.; Narita, M.; Ichisaka, T.; Tomoda, K.; Yamanaka, S. Induction of Pluripotent Stem Cells from Adult Human Fibroblasts by Defined Factors. Cell 2007, 131, 861-872. [CrossRef] [PubMed]

31. Abad, M.; Mosteiro, L.; Pantoja, C.; Cañamero, M.; Rayon, T.; Ors, I.; Graña, O.; Megías, D.; Domínguez, O.; Martínez, D.; et al. Reprogramming in Vivo Produces Teratomas and IPS Cells with Totipotency Features. Nature 2013, 502, 340-345. [CrossRef]

32. Cai, J.; Yang, M.; Poremsky, E.; Kidd, S.; Schneider, J.S.; Iacovitti, L. Dopaminergic Neurons Derived from Human Induced Pluripotent Stem Cells Survive and Integrate into 6-OHDA-Lesioned Rats. Stem Cells Dev. 2010, 19, 1017-1023. [CrossRef]

33. Wernig, M.; Zhao, J.-P.; Pruszak, J.; Hedlund, E.; Fu, D.; Soldner, F.; Broccoli, V.; Constantine-Paton, M.; Isacson, O.; Jaenisch, R. Neurons Derived from Reprogrammed Fibroblasts Functionally Integrate into the Fetal Brain and Improve Symptoms of Rats with Parkinson's Disease. Proc. Natl. Acad. Sci. USA 2008, 105, 5856-5861. [CrossRef] [PubMed]

34. Ray, S.; Maunsell, J.H.R. Different Origins of Gamma Rhythm and High-Gamma Activity in Macaque Visual Cortex. PLOS Biol. 2011, 9, e1000610. [CrossRef]

35. Swistowski, A.; Peng, J.; Liu, Q.; Mali, P.; Rao, M.S.; Cheng, L.; Zeng, X. Efficient Generation of Functional Dopaminergic Neurons from Human Induced Pluripotent Stem Cells under Defined Conditions. Stem Cells 2010, 28, 1893-1904. [CrossRef] [PubMed]

36. Soldner, F.; Hockemeyer, D.; Beard, C.; Gao, Q.; Bell, G.W.; Cook, E.G.; Hargus, G.; Blak, A.; Cooper, O.; Mitalipova, M.; et al. Parkinson's Disease Patient-Derived Induced Pluripotent Stem Cells Free of Viral Reprogramming Factors. Cell 2009, 136, 964-977. [CrossRef] [PubMed]

37. Dimos, J.T.; Rodolfa, K.T.; Niakan, K.K.; Weisenthal, L.M.; Mitsumoto, H.; Chung, W.; Croft, G.F.; Saphier, G.; Leibel, R.; Goland, R.; et al. Induced Pluripotent Stem Cells Generated from Patients with ALS Can Be Differentiated into Motor Neurons. Science 2008, 321, 1218-1221. [CrossRef]

38. Park, I.-H.; Arora, N.; Huo, H.; Maherali, N.; Ahfeldt, T.; Shimamura, A.; Lensch, M.W.; Cowan, C.; Hochedlinger, K.; Daley, G.Q. Disease-Specific Induced Pluripotent Stem Cells. Cell 2008, 134, 877-886. [CrossRef]

39. Esteban, M.A.; Xu, J.; Yang, J.; Peng, M.; Qin, D.; Li, W.; Jiang, Z.; Chen, J.; Deng, K.; Zhong, M.; et al. Generation of Induced Pluripotent Stem Cell Lines from Tibetan Miniature Pig. J. Biol. Chem. 2009, 284, 17634-17640. [CrossRef] [PubMed]

40. Chang, M.-Y.; Kim, D.; Kim, C.-H.; Kang, H.-C.; Yang, E.; Moon, J.-I.; Ko, S.; Park, J.; Park, K.-S.; Lee, K.-A.; et al. Direct Reprogramming of Rat Neural Precursor Cells and Fibroblasts into Pluripotent Stem Cells. PLoS ONE 2010, 5, e9838. [CrossRef]

41. Liu, H.; Zhu, F.; Yong, J.; Zhang, P.; Hou, P.; Li, H.; Jiang, W.; Cai, J.; Liu, M.; Cui, K.; et al. Generation of Induced Pluripotent Stem Cells from Adult Rhesus Monkey Fibroblasts. Cell Stem Cell 2008, 3, 587-590. [CrossRef] [PubMed]

42. Wu, Y.; Zhang, Y.; Mishra, A.; Tardif, S.D.; Hornsby, P.J. Generation of Induced Pluripotent Stem Cells from Newborn Marmoset Skin Fibroblasts. Stem Cell Res. 2010, 4, 180-188. [CrossRef]

43. Kim, J.B.; Greber, B.; Araúzo-Bravo, M.J.; Meyer, J.; Park, K.I.; Zaehres, H.; Schöler, H.R. Direct Reprogramming of Human Neural Stem Cells by OCT4. Nature 2009, 461, 649-653. [CrossRef] [PubMed]

44. Kaji, K.; Norrby, K.; Paca, A.; Mileikovsky, M.; Mohseni, P.; Woltjen, K. Virus-Free Induction of Pluripotency and Subsequent Excision of Reprogramming Factors. Nature 2009, 458, 771-775. [CrossRef] [PubMed]

45. Woltjen, K.; Michael, I.P.; Mohseni, P.; Desai, R.; Mileikovsky, M.; Hämäläinen, R.; Cowling, R.; Wang, W.; Liu, P.; Gertsenstein, M.; et al. PiggyBac Transposition Reprograms Fibroblasts to Induced Pluripotent Stem Cells. Nature 2009, 458, 766-770. [CrossRef]

46. Okita, K.; Nakagawa, M.; Hyenjong, H.; Ichisaka, T.; Yamanaka, S. Generation of Mouse Induced Pluripotent Stem Cells without Viral Vectors. Science 2008, 322, 949-953. [CrossRef]

47. Yu, J.; Hu, K.; Smuga-Otto, K.; Tian, S.; Stewart, R.; Slukvin, I.I.; Thomson, J.A. Human Induced Pluripotent Stem Cells Free of Vector and Transgene Sequences. Science 2009, 324, 797-801. [CrossRef]

48. Warren, L.; Manos, P.D.; Ahfeldt, T.; Loh, Y.-H.; Li, H.; Lau, F.; Ebina, W.; Mandal, P.K.; Smith, Z.D.; Meissner, A.; et al. Highly Efficient Reprogramming to Pluripotency and Directed Differentiation of Human Cells with Synthetic Modified MRNA. Cell Stem Cell 2010, 7, 618-630. [CrossRef] [PubMed]

49. Zhou, H.; Wu, S.; Joo, J.Y.; Zhu, S.; Han, D.W.; Lin, T.; Trauger, S.; Bien, G.; Yao, S.; Zhu, Y.; et al. Generation of Induced Pluripotent Stem Cells Using Recombinant Proteins. Cell Stem Cell 2009, 4, 381-384. [CrossRef]

50. Lyssiotis, C.A.; Foreman, R.K.; Staerk, J.; Garcia, M.; Mathur, D.; Markoulaki, S.; Hanna, J.; Lairson, L.L.; Charette, B.D.; Bouchez, L.C.; et al. Reprogramming of Murine Fibroblasts to Induced Pluripotent Stem Cells with Chemical Complementation of Klf4. Proc. Natl. Acad. Sci. USA 2009, 106, 8912-8917. [CrossRef] 
51. Jang, J.; Yoo, J.-E.; Lee, J.-A.; Lee, D.R.; Kim, J.Y.; Huh, Y.J.; Kim, D.-S.; Park, C.-Y.; Hwang, D.-Y.; Kim, H.-S.; et al. Disease-Specific Induced Pluripotent Stem Cells: A Platform for Human Disease Modeling and Drug Discovery. Exp. Mol. Med. 2012, 44, 202-213. [CrossRef]

52. Chou, Y.-F.; Chen, H.-H.; Eijpe, M.; Yabuuchi, A.; Chenoweth, J.G.; Tesar, P.; Lu, J.; McKay, R.D.G.; Geijsen, N. The Growth Factor Environment Defines Distinct Pluripotent Ground States in Novel Blastocyst-Derived Stem Cells. Cell 2008, 135, 449-461. [CrossRef]

53. Liu, Z.; Cheung, H.-H. Stem Cell-Based Therapies for Parkinson Disease. Int. J. Mol. Sci. 2020, 21, 8060. [CrossRef]

54. Saeedi, P.; Halabian, R.; Imani Fooladi, A.A. A Revealing Review of Mesenchymal Stem Cells Therapy, Clinical Perspectives and Modification Strategies. Stem Cell Investig. 2019, 6, 34. [CrossRef] [PubMed]

55. Taylor, C.J.; Peacock, S.; Chaudhry, A.N.; Bradley, J.A.; Bolton, E.M. Generating an IPSC Bank for HLA-Matched Tissue Transplantation Based on Known Donor and Recipient HLA Types. Cell Stem Cell 2012, 11, 147-152. [CrossRef]

56. Nakatsuji, N.; Nakajima, F.; Tokunaga, K. HLA-Haplotype Banking and IPS Cells. Nat. Biotechnol. 2008, 26, 739-740. [CrossRef] [PubMed]

57. Lee, S.; Huh, J.Y.; Turner, D.M.; Lee, S.; Robinson, J.; Stein, J.E.; Shim, S.H.; Hong, C.P.; Kang, M.S.; Nakagawa, M.; et al. Repurposing the Cord Blood Bank for Haplobanking of HLA-Homozygous IPSCs and Their Usefulness to Multiple Populations. Stem Cells 2018, 36, 1552-1566. [CrossRef] [PubMed]

58. Jang, Y.; Choi, J.; Park, N.; Kang, J.; Kim, M.; Kim, Y.; Ju, J.H. Development of Immunocompatible Pluripotent Stem Cells via CRISPR-Based Human Leukocyte Antigen Engineering. Exp. Mol. Med. 2019, 51, 1-11. [CrossRef] [PubMed]

59. Vescovi, A.L.; Gritti, A.; Galli, R.; Parati, E.A. Isolation and Intracerebral Grafting of Nontransformed Multipotential Embryonic Human CNS Stem Cells. J. Neurotrauma 1999, 16, 689-693. [CrossRef] [PubMed]

60. Gritti, A.; Frölichsthal-Schoeller, P.; Galli, R.; Parati, E.A.; Cova, L.; Pagano, S.F.; Bjornson, C.R.; Vescovi, A.L. Epidermal and Fibroblast Growth Factors Behave as Mitogenic Regulators for a Single Multipotent Stem Cell-like Population from the Subventricular Region of the Adult Mouse Forebrain. J. Neurosci. Off. J. Soc. Neurosci. 1999, 19, 3287-3297. [CrossRef]

61. Bottai, D.; Fiocco, R.; Gelain, F.; Defilippis, L.; Galli, R.; Gritti, A.; Vescovi, L.A. Neural Stem Cells in the Adult Nervous System. J. Hematother. Stem Cell Res. 2003, 12, 655-670. [CrossRef] [PubMed]

62. Pluchino, S.; Quattrini, A.; Brambilla, E.; Gritti, A.; Salani, G.; Dina, G.; Galli, R.; Del Carro, U.; Amadio, S.; Bergami, A.; et al. Injection of Adult Neurospheres Induces Recovery in a Chronic Model of Multiple Sclerosis. Nature 2003, 422, 688-694. [CrossRef] [PubMed]

63. Bottai, D.; Madaschi, L.; Di Giulio, A.M.; Gorio, A. Viability-Dependent Promoting Action of Adult Neural Precursors in Spinal Cord Injury. Mol. Med. 2008, 14, 634-644. [CrossRef]

64. Fiorio, M.; Tinazzi, M.; Aglioti, S.M. Selective Impairment of Hand Mental Rotation in Patients with Focal Hand Dystonia. Brain J. Neurol. 2006, 129, 47-54. [CrossRef]

65. Xu, L.; Shen, P.; Hazel, T.; Johe, K.; Koliatsos, V.E. Dual Transplantation of Human Neural Stem Cells into Cervical and Lumbar Cord Ameliorates Motor Neuron Disease in SOD1 Transgenic Rats. Neurosci. Lett. 2011, 494, 222-226. [CrossRef] [PubMed]

66. De Coppi, P.; Bartsch, G.; Siddiqui, M.M.; Xu, T.; Santos, C.C.; Perin, L.; Mostoslavsky, G.; Serre, A.C.; Snyder, E.Y.; Yoo, J.J.; et al. Isolation of Amniotic Stem Cell Lines with Potential for Therapy. Nat. Biotechnol. 2007, 25, 100-106. [CrossRef]

67. Bottai, D.; Cigognini, D.; Nicora, E.; Moro, M.; Grimoldi, M.G.; Adami, R.; Abrignani, S.; Marconi, A.M.; Di Giulio, A.M.; Gorio, A. Third Trimester Amniotic Fluid Cells with the Capacity to Develop Neural Phenotypes and with Heterogeneity among Sub-Populations. Restor. Neurol. Neurosci. 2012, 30, 55-68. [CrossRef]

68. Moroni, L.; Fornasari, P.M. Human Mesenchymal Stem Cells: A Bank Perspective on the Isolation, Characterization and Potential of Alternative Sources for the Regeneration of Musculoskeletal Tissues. J. Cell. Physiol. 2013, 228, 680-687. [CrossRef]

69. Rao, M.S.; Mattson, M.P. Stem Cells and Aging: Expanding the Possibilities. Mech. Ageing Dev. 2001, 122, 713-734. [CrossRef]

70. Rubio, D.; Garcia-Castro, J.; Martín, M.C.; de la Fuente, R.; Cigudosa, J.C.; Lloyd, A.C.; Bernad, A. Spontaneous Human Adult Stem Cell Transformation. Cancer Res. 2005, 65, 3035-3039. [CrossRef]

71. De la Fuente, R.; Bernad, A.; Garcia-Castro, J.; Martin, M.C.; Cigudosa, J.C. Retraction: Spontaneous Human Adult Stem Cell Transformation. Cancer Res. 2010, 70, 6682. [CrossRef] [PubMed]

72. Kobolak, J.; Dinnyes, A.; Memic, A.; Khademhosseini, A.; Mobasheri, A. Mesenchymal Stem Cells: Identification, Phenotypic Characterization, Biological Properties and Potential for Regenerative Medicine through Biomaterial Micro-Engineering of Their Niche. Methods 2016, 99, 62-68. [CrossRef] [PubMed]

73. Bianco, P. “Mesenchymal” Stem Cells. Annu. Rev. Cell Dev. Biol. 2014, 30, 677-704. [CrossRef] [PubMed]

74. Wu, J.; Zhang, W.; Ran, Q.; Xiang, Y.; Zhong, J.F.; Li, S.C.; Li, Z. The Differentiation Balance of Bone Marrow Mesenchymal Stem Cells Is Crucial to Hematopoiesis. Stem Cells Int. 2018, 2018, 1540148. [CrossRef]

75. Miao, C.; Lei, M.; Hu, W.; Han, S.; Wang, Q. A Brief Review: The Therapeutic Potential of Bone Marrow Mesenchymal Stem Cells in Myocardial Infarction. Stem Cell Res. Ther. 2017, 8, 242. [CrossRef]

76. Klontzas, M.E.; Kenanidis, E.I.; Heliotis, M.; Tsiridis, E.; Mantalaris, A. Bone and Cartilage Regeneration with the Use of Umbilical Cord Mesenchymal Stem Cells. Expert Opin. Biol. Ther. 2015, 15, 1541-1552. [CrossRef] [PubMed]

77. Kargozar, S.; Lotfibakhshaiesh, N.; Ai, J.; Mozafari, M.; Brouki Milan, P.; Hamzehlou, S.; Barati, M.; Baino, F.; Hill, R.G.; Joghataei, M.T. Strontium- and Cobalt-Substituted Bioactive Glasses Seeded with Human Umbilical Cord Perivascular Cells to Promote Bone Regeneration via Enhanced Osteogenic and Angiogenic Activities. Acta Biomater. 2017, 58, 502-514. [CrossRef] 
78. Tsang, W.P.; Shu, Y.; Kwok, P.L.; Zhang, F.; Lee, K.K.H.; Tang, M.K.; Li, G.; Chan, K.M.; Chan, W.-Y.; Wan, C. CD146+ Human Umbilical Cord Perivascular Cells Maintain Stemness under Hypoxia and as a Cell Source for Skeletal Regeneration. PLoS ONE 2013, 8, e76153. [CrossRef] [PubMed]

79. Bosch, J.; Houben, A.P.; Radke, T.F.; Stapelkamp, D.; Bünemann, E.; Balan, P.; Buchheiser, A.; Liedtke, S.; Kögler, G. Distinct Differentiation Potential of "MSC" Derived from Cord Blood and Umbilical Cord: Are Cord-Derived Cells True Mesenchymal Stromal Cells? Stem Cells Dev. 2012, 21, 1977-1988. [CrossRef] [PubMed]

80. Jin, H.J.; Bae, Y.K.; Kim, M.; Kwon, S.-J.; Jeon, H.B.; Choi, S.J.; Kim, S.W.; Yang, Y.S.; Oh, W.; Chang, J.W. Comparative Analysis of Human Mesenchymal Stem Cells from Bone Marrow, Adipose Tissue, and Umbilical Cord Blood as Sources of Cell Therapy. Int. J. Mol. Sci. 2013, 14, 17986-18001. [CrossRef] [PubMed]

81. Bosch, J.; Houben, A.P.; Hennicke, T.; Deenen, R.; Köhrer, K.; Liedtke, S.; Kögler, G. Comparing the Gene Expression Profile of Stromal Cells from Human Cord Blood and Bone Marrow: Lack of the Typical "Bone" Signature in Cord Blood Cells. Stem Cells Int. 2013, 2013, e631984. [CrossRef] [PubMed]

82. Maher, S.; Kolieb, E.; Sabik, N.A.; Abd-Elhalim, D.; El-Serafi, A.T.; El-Wazir, Y. Comparison of the Osteogenic Differentiation Potential of Mesenchymal Cells Isolated from Human Bone Marrow, Umbilical Cord Blood and Placenta Derived Stem Cells. Beni-Suef Univ. J. Basic Appl. Sci. 2015, 4, 80-85. [CrossRef]

83. McDonald, C.A.; Fahey, M.C.; Jenkin, G.; Miller, S.L. Umbilical Cord Blood Cells for Treatment of Cerebral Palsy; Timing and Treatment Options. Pediatr. Res. 2018, 83, 333-344. [CrossRef]

84. Jin, Y.-Z.; Lee, J.H. Mesenchymal Stem Cell Therapy for Bone Regeneration. Clin. Orthop. Surg. 2018, 10, 271-278. [CrossRef] [PubMed]

85. Steinbeck, J.A.; Studer, L. Moving Stem Cells to the Clinic: Potential and Limitations for Brain Repair. Neuron 2015, 86, 187-206. [CrossRef]

86. Cardoso, T.; Adler, A.F.; Mattsson, B.; Hoban, D.B.; Nolbrant, S.; Wahlestedt, J.N.; Kirkeby, A.; Grealish, S.; Björklund, A.; Parmar, M. Target-Specific Forebrain Projections and Appropriate Synaptic Inputs of HESC-Derived Dopamine Neurons Grafted to the Midbrain of Parkinsonian Rats. J. Comp. Neurol. 2018, 526, 2133-2146. [CrossRef]

87. Carpenter, M.K. Regulatory Considerations for Pluripotent Stem Cell Therapies. Prog. Brain Res. 2017, 230, 151-163. [CrossRef]

88. Dunnett, S.B.; Rosser, A.E. Challenges for Taking Primary and Stem Cells into Clinical Neurotransplantation Trials for Neurodegenerative Disease. Neurobiol. Dis. 2014, 61, 79-89. [CrossRef] [PubMed]

89. Forraz, N.; Wright, K.E.; Jurga, M.; McGuckin, C.P. Experimental Therapies for Repair of the Central Nervous System: Stem Cells and Tissue Engineering. J. Tissue Eng. Regen. Med. 2013, 7, 523-536. [CrossRef]

90. Cossetti, C.; Alfaro-Cervello, C.; Donegà, M.; Tyzack, G.; Pluchino, S. New Perspectives of Tissue Remodelling with Neural Stem and Progenitor Cell-Based Therapies. Cell Tissue Res. 2012, 349, 321-329. [CrossRef] [PubMed]

91. Dzamba, D.; Harantova, L.; Butenko, O.; Anderova, M. Glial Cells-The Key Elements of Alzheimer's Disease. Curr. Alzheimer Res. 2016, 13, 894-911. [CrossRef] [PubMed]

92. Mendonça, L.S.; Nóbrega, C.; Hirai, H.; Kaspar, B.K.; Pereira de Almeida, L. Transplantation of Cerebellar Neural Stem Cells Improves Motor Coordination and Neuropathology in Machado-Joseph Disease Mice. Brain J. Neurol. 2015, 138, $320-335$. [CrossRef]

93. Wang, Z.; Yao, W.; Deng, Q.; Zhang, X.; Zhang, J. Protective Effects of BDNF Overexpression Bone Marrow Stromal Cell Transplantation in Rat Models of Traumatic Brain Injury. J. Mol. Neurosci. MN 2013, 49, 409-416. [CrossRef]

94. Ma, H.; Yu, B.; Kong, L.; Zhang, Y.; Shi, Y. Neural Stem Cells Over-Expressing Brain-Derived Neurotrophic Factor (BDNF) Stimulate Synaptic Protein Expression and Promote Functional Recovery Following Transplantation in Rat Model of Traumatic Brain Injury. Neurochem. Res. 2012, 37, 69-83. [CrossRef]

95. Bacigaluppi, M.; Pluchino, S.; Peruzzotti-Jametti, L.; Jametti, L.P.; Kilic, E.; Kilic, U.; Salani, G.; Brambilla, E.; West, M.J.; Comi, G.; et al. Delayed Post-Ischaemic Neuroprotection Following Systemic Neural Stem Cell Transplantation Involves Multiple Mechanisms. Brain J. Neurol. 2009, 132, 2239-2251. [CrossRef] [PubMed]

96. Boltze, J.; Zille, M.; Schilling, S.; Gelderblom, M.; Bix, G.J.; Walczak, P.; Harms, C.; Rosado-de-Castro, P.H.; Pinteaux, E. CuttingEdge Approaches for CNS Protection and Repair: Focus on Vascular and Degenerative Disorders; Frontiers Media SA: Lausanne, Switzerland, 2021; ISBN 978-2-88971-177-2.

97. Camponeschi, F.; Valensin, D.; Tessari, I.; Bubacco, L.; Dell’Acqua, S.; Casella, L.; Monzani, E.; Gaggelli, E.; Valensin, G. Copper(I)$\alpha$-Synuclein Interaction: Structural Description of Two Independent and Competing Metal Binding Sites. Inorg. Chem. 2013, 52, 1358-1367. [CrossRef] [PubMed]

98. Ahmed, S.S.S.J.; Santosh, W. Metallomic Profiling and Linkage Map Analysis of Early Parkinson's Disease: A New Insight to Aluminum Marker for the Possible Diagnosis. PLoS ONE 2010, 5, e11252. [CrossRef] [PubMed]

99. Younes-Mhenni, S.; Aissi, M.; Mokni, N.; Boughammoura-Bouatay, A.; Chebel, S.; Frih-Ayed, M.; Kerkeni, A.; Bost, M.; Chazot, G.; Sfar, M.T.; et al. Serum Copper, Zinc and Selenium Levels in Tunisian Patients with Parkinson's Disease. Tunis. Med. 2013, 91, 402-405. [PubMed]

100. Tolleson, C.M.; Fang, J.Y. Advances in the Mechanisms of Parkinson's Disease. Discov. Med. 2013, 15, 61-66. [PubMed]

101. Pringsheim, T.; Jette, N.; Frolkis, A.; Steeves, T.D.L. The Prevalence of Parkinson's Disease: A Systematic Review and MetaAnalysis. Mov. Disord. Off. J. Mov. Disord. Soc. 2014, 29, 1583-1590. [CrossRef] [PubMed] 
102. Yu, H.; Sun, T.; An, J.; Wen, L.; Liu, F.; Bu, Z.; Cui, Y.; Feng, J. Potential Roles of Exosomes in Parkinson's Disease: From Pathogenesis, Diagnosis, and Treatment to Prognosis. Front. Cell Dev. Biol. 2020, 8, 86. [CrossRef]

103. Chang, Y.-H.; Wu, K.-C.; Harn, H.-J.; Lin, S.-Z.; Ding, D.-C. Exosomes and Stem Cells in Degenerative Disease Diagnosis and Therapy. Cell Transplant. 2018, 27, 349-363. [CrossRef] [PubMed]

104. Teixeira, F.G.; Carvalho, M.M.; Panchalingam, K.M.; Rodrigues, A.J.; Mendes-Pinheiro, B.; Anjo, S.; Manadas, B.; Behie, L.A.; Sousa, N.; Salgado, A.J. Impact of the Secretome of Human Mesenchymal Stem Cells on Brain Structure and Animal Behavior in a Rat Model of Parkinson's Disease. Stem Cells Transl. Med. 2017, 6, 634-646. [CrossRef] [PubMed]

105. Clark, C.M.; Xie, S.; Chittams, J.; Ewbank, D.; Peskind, E.; Galasko, D.; Morris, J.C.; McKeel, D.W.; Farlow, M.; Weitlauf, S.L.; et al. Cerebrospinal Fluid Tau and Beta-Amyloid: How Well Do These Biomarkers Reflect Autopsy-Confirmed Dementia Diagnoses? Arch. Neurol. 2003, 60, 1696-1702. [CrossRef]

106. Xin, H.; Katakowski, M.; Wang, F.; Qian, J.-Y.; Liu, X.S.; Ali, M.M.; Buller, B.; Zhang, Z.G.; Chopp, M. MicroRNA-17-92 Cluster in Exosomes Enhance Neuroplasticity and Functional Recovery After Stroke in Rats. Stroke 2017, 48, 747-753. [CrossRef]

107. Mohanraj, R.; Norrie, J.; Stephen, L.J.; Kelly, K.; Hitiris, N.; Brodie, M.J. Mortality in Adults with Newly Diagnosed and Chronic Epilepsy: A Retrospective Comparative Study. Lancet Neurol. 2006, 5, 481-487. [CrossRef]

108. Lawn, N.D.; Bamlet, W.R.; Radhakrishnan, K.; O’Brien, P.C.; So, E.L. Injuries Due to Seizures in Persons with Epilepsy: A Population-Based Study. Neurology 2004, 63, 1565-1570. [CrossRef]

109. McCagh, J.; Fisk, J.E.; Baker, G.A. Epilepsy, Psychosocial and Cognitive Functioning. Epilepsy Res. 2009, 86, 1-14. [CrossRef]

110. Jobst, B.C.; Cascino, G.D. Resective Epilepsy Surgery for Drug-Resistant Focal Epilepsy: A Review. JAMA 2015, 313, 285-293. [CrossRef]

111. Krumholz, A.; Wiebe, S.; Gronseth, G.; Shinnar, S.; Levisohn, P.; Ting, T.; Hopp, J.; Shafer, P.; Morris, H.; Seiden, L.; et al. Practice Parameter: Evaluating an Apparent Unprovoked First Seizure in Adults (an Evidence-Based Review): Report of the Quality Standards Subcommittee of the American Academy of Neurology and the American Epilepsy Society. Neurology 2007, 69, 1996-2007. [CrossRef]

112. Kang, J.Y.; Wu, C.; Tracy, J.; Lorenzo, M.; Evans, J.; Nei, M.; Skidmore, C.; Mintzer, S.; Sharan, A.D.; Sperling, M.R. Laser Interstitial Thermal Therapy for Medically Intractable Mesial Temporal Lobe Epilepsy. Epilepsia 2016, 57, 325-334. [CrossRef]

113. Arcos, A.; Romero, L.; Gelabert, M.; Prieto, A.; Pardo, J.; Osorio, X.R.; Arráez, M.A. Can We Predict the Response in the Treatment of Epilepsy with Vagus Nerve Stimulation? Neurosurg. Rev. 2014, 37, 661-668. [CrossRef]

114. Kuba, R.; Brázdil, M.; Novák, Z.; Chrastina, J.; Rektor, I. Effect of Vagal Nerve Stimulation on Patients with Bitemporal Epilepsy. Eur. J. Neurol. 2003, 10, 91-94. [CrossRef] [PubMed]

115. Guerreiro, C.A.M. Epilepsy: Is There Hope? Indian J. Med. Res. 2016, 144, 657-660. [CrossRef]

116. Wang, A.J.; Bick, S.K.; Williams, Z.M. Vagus Nerve Stimulation versus Responsive Neurostimulator System in Patients with Temporal Lobe Epilepsy. Stereotact. Funct. Neurosurg. 2020, 98, 21-29. [CrossRef] [PubMed]

117. Kobelt, G.; Thompson, A.; Berg, J.; Gannedahl, M.; Eriksson, J. New Insights into the Burden and Costs of Multiple Sclerosis in Europe. Mult. Scler. J. 2017, 23, 1123-1136. [CrossRef]

118. Browne, P.; Chandraratna, D.; Angood, C.; Tremlett, H.; Baker, C.; Taylor, B.V.; Thompson, A.J. Atlas of Multiple Sclerosis 2013: A Growing Global Problem with Widespread Inequity. Neurology 2014, 83, 1022-1024. [CrossRef] [PubMed]

119. Cristiano, E.; Patrucco, L.; Miguez, J.; Giunta, D.; Peroni, J.; Rojas, J.I. Increasing Incidence of Multiple Sclerosis among Women in Buenos Aires: A 22 Year Health Maintenance Organization Based Study. Neurol. Sci. Off. J. Ital. Neurol. Soc. Ital. Soc. Clin. Neurophysiol. 2016, 37, 1621-1626. [CrossRef] [PubMed]

120. Greenfield, A.L.; Hauser, S.L. B-Cell Therapy for Multiple Sclerosis: Entering an Era. Ann. Neurol. 2018, 83, 13-26. [CrossRef] [PubMed]

121. Leray, E.; Yaouanq, J.; Le Page, E.; Coustans, M.; Laplaud, D.; Oger, J.; Edan, G. Evidence for a Two-Stage Disability Progression in Multiple Sclerosis. Brain 2010, 133, 1900-1913. [CrossRef]

122. Coles, A.J.; Cox, A.; Le Page, E.; Jones, J.; Trip, S.A.; Deans, J.; Seaman, S.; Miller, D.H.; Hale, G.; Waldmann, H.; et al. The Window of Therapeutic Opportunity in Multiple Sclerosis: Evidence from Monoclonal Antibody Therapy. J. Neurol. 2006, 253, 98-108. [CrossRef]

123. Ramagopalan, S.V.; Dobson, R.; Meier, U.C.; Giovannoni, G. Multiple Sclerosis: Risk Factors, Prodromes, and Potential Causal Pathways. Lancet Neurol. 2010, 9, 727-739. [CrossRef]

124. Dobson, R.; Giovannoni, G. Multiple Sclerosis-A Review. Eur. J. Neurol. 2019, 26, 27-40. [CrossRef]

125. Rizvi, S.A.; Stone, J.A.; Chaudhry, S.T.; Haddad, N.; Wong, B.; Grimes, J.O. Clinical decision-making in the management of multiple sclerosis. In Clinical Neuroimmunology: Multiple Sclerosis and Related Disorders; Rizvi, S.A., Cahill, J.F., Coyle, P.K., Eds.; Current Clinical Neurology; Springer International Publishing: Cham, Switzerland, 2020; pp. 159-177. ISBN 978-3-030-24436-1.

126. Gross, R.H.; Corboy, J.R. Monitoring, Switching, and Stopping Multiple Sclerosis Disease-Modifying Therapies. Continuum 2019, 25, 715-735. [CrossRef]

127. Li, Z.; Liu, F.; He, X.; Yang, X.; Shan, F.; Feng, J. Exosomes Derived from Mesenchymal Stem Cells Attenuate Inflammation and Demyelination of the Central Nervous System in EAE Rats by Regulating the Polarization of Microglia. Int. Immunopharmacol. 2019, 67, 268-280. [CrossRef] 
128. Farinazzo, A.; Angiari, S.; Turano, E.; Bistaffa, E.; Dusi, S.; Ruggieri, S.; Bonafede, R.; Mariotti, R.; Constantin, G.; Bonetti, B. Nanovesicles from Adipose-Derived Mesenchymal Stem Cells Inhibit T Lymphocyte Trafficking and Ameliorate Chronic Experimental Autoimmune Encephalomyelitis. Sci. Rep. 2018, 8, 7473. [CrossRef]

129. Hands, S.L.; Mason, R.; Sajjad, M.U.; Giorgini, F.; Wyttenbach, A. Metallothioneins and Copper Metabolism Are Candidate Therapeutic Targets in Huntington's Disease. Biochem. Soc. Trans. 2010, 38, 552-558. [CrossRef]

130. Dusek, P.; Jankovic, J.; Le, W. Iron Dysregulation in Movement Disorders. Neurobiol. Dis. 2012, 46, 1-18. [CrossRef]

131. Malecki, E.A.; Devenyi, A.G.; Beard, J.L.; Connor, J.R. Existing and Emerging Mechanisms for Transport of Iron and Manganese to the Brain. J. Neurosci. Res. 1999, 56, 113-122. [CrossRef]

132. Caron, N.S.; Wright, G.E.; Hayden, M.R. Huntington Disease. In GeneReviews ${ }^{\circledR}$; Adam, M.P., Ardinger, H.H., Pagon, R.A., Wallace, S.E., Bean, L.J., Mirzaa, G., Amemiya, A., Eds.; University of Washington, Seattle: Seattle, WA, USA, 1993.

133. Croese, T.; Furlan, R. Extracellular Vesicles in Neurodegenerative Diseases. Mol. Asp. Med. 2018, 60, 52-61. [CrossRef]

134. Lee, M.; Liu, T.; Im, W.; Kim, M. Exosomes from Adipose-Derived Stem Cells Ameliorate Phenotype of Huntington's Disease in Vitro Model. Eur. J. Neurosci. 2016, 44, 2114-2119. [CrossRef]

135. Lee, S.-T.; Im, W.; Ban, J.-J.; Lee, M.; Jung, K.-H.; Lee, S.K.; Chu, K.; Kim, M. Exosome-Based Delivery of MiR-124 in a Huntington's Disease Model. J. Mov. Disord. 2017, 10, 45-52. [CrossRef]

136. Trumbull, K.A.; Beckman, J.S. A Role for Copper in the Toxicity of Zinc-Deficient Superoxide Dismutase to Motor Neurons in Amyotrophic Lateral Sclerosis. Antioxid. Redox Signal. 2009, 11, 1627-1639. [CrossRef] [PubMed]

137. Vinceti, M.; Bottecchi, I.; Fan, A.; Finkelstein, Y.; Mandrioli, J. Are Environmental Exposures to Selenium, Heavy Metals, and Pesticides Risk Factors for Amyotrophic Lateral Sclerosis? Rev. Environ. Health 2012, 27, 19-41. [CrossRef]

138. Kanias, G.D.; Kapaki, E. Trace Elements, Age, and Sex in Amyotrophic Lateral Sclerosis Disease. Biol. Trace Elem. Res. 1997, 56, 187-201. [CrossRef] [PubMed]

139. Ignjatović, A.; Stević, Z.; Lavrnić, D.; Nikolić-Kokić, A.; Blagojević, D.; Spasić, M.; Spasojević, I. Inappropriately Chelated Iron in the Cerebrospinal Fluid of Amyotrophic Lateral Sclerosis Patients. Amyotroph. Lateral Scler. Off. Publ. World Fed. Neurol. Res. Group Mot. Neuron Dis. 2012, 13, 357-362. [CrossRef] [PubMed]

140. Roos, P.M.; Lierhagen, S.; Flaten, T.P.; Syversen, T.; Vesterberg, O.; Nordberg, M. Manganese in Cerebrospinal Fluid and Blood Plasma of Patients with Amyotrophic Lateral Sclerosis. Exp. Biol. Med. 2012, 237, 803-810. [CrossRef]

141. Mitchell, R.M.; Simmons, Z.; Beard, J.L.; Stephens, H.E.; Connor, J.R. Plasma Biomarkers Associated with ALS and Their Relationship to Iron Homeostasis. Muscle Nerve 2010, 42, 95-103. [CrossRef]

142. Nadjar, Y.; Gordon, P.; Corcia, P.; Bensimon, G.; Pieroni, L.; Meininger, V.; Salachas, F. Elevated Serum Ferritin Is Associated with Reduced Survival in Amyotrophic Lateral Sclerosis. PLoS ONE 2012, 7, e45034. [CrossRef]

143. Pfaender, S.; Grabrucker, A.M. Characterization of Biometal Profiles in Neurological Disorders. Met. Integr. Biometal Sci. 2014, 6, 960-977. [CrossRef]

144. Azevedo, F.A.C.; Carvalho, L.R.B.; Grinberg, L.T.; Farfel, J.M.; Ferretti, R.E.L.; Leite, R.E.P.; Jacob Filho, W.; Lent, R.; HerculanoHouzel, S. Equal Numbers of Neuronal and Nonneuronal Cells Make the Human Brain an Isometrically Scaled-up Primate Brain. J. Comp. Neurol. 2009, 513, 532-541. [CrossRef]

145. Pelvig, D.P.; Pakkenberg, H.; Stark, A.K.; Pakkenberg, B. Neocortical Glial Cell Numbers in Human Brains. Neurobiol. Aging 2008, 29, 1754-1762. [CrossRef]

146. Dwork, A.J.; Mancevski, B.; Rosoklija, G. White Matter and Cognitive Function in Schizophrenia. Int. J. Neuropsychopharmacol. 2007, 10, 513-536. [CrossRef] [PubMed]

147. Bernstein, H.-G.; Steiner, J.; Guest, P.C.; Dobrowolny, H.; Bogerts, B. Glial Cells as Key Players in Schizophrenia Pathology: Recent Insights and Concepts of Therapy. Schizophr. Res. 2015, 161, 4-18. [CrossRef]

148. Yamamuro, K.; Kimoto, S.; Rosen, K.M.; Kishimoto, T.; Makinodan, M. Potential Primary Roles of Glial Cells in the Mechanisms of Psychiatric Disorders. Front. Cell. Neurosci. 2015, 9, 154. [CrossRef]

149. Walterfang, M.; Wood, S.J.; Velakoulis, D.; Copolov, D.; Pantelis, C. Diseases of White Matter and Schizophrenia-like Psychosis. Aust. N. Z. J. Psychiatry 2005, 39, 746-756. [CrossRef] [PubMed]

150. Mighdoll, M.I.; Tao, R.; Kleinman, J.E.; Hyde, T.M. Myelin, Myelin-Related Disorders, and Psychosis. Schizophr. Res. 2015, 161, 85-93. [CrossRef] [PubMed]

151. Rempel-Clower, N.L.; Zola, S.M.; Squire, L.R.; Amaral, D.G. Three Cases of Enduring Memory Impairment after Bilateral Damage Limited to the Hippocampal Formation. J. Neurosci. Off. J. Soc. Neurosci. 1996, 16, 5233-5255. [CrossRef]

152. Squire, L.R. Memory and the Hippocampus: A Synthesis from Findings with Rats, Monkeys, and Humans. Psychol. Rev. 1992, 99, 195-231. [CrossRef] [PubMed]

153. Squire, L.R.; Zola-Morgan, S. The Medial Temporal Lobe Memory System. Science 1991, 253, 1380-1386. [CrossRef]

154. Grasby, P.M.; Frith, C.D.; Friston, K.J.; Simpson, J.; Fletcher, P.C.; Frackowiak, R.S.; Dolan, R.J. A Graded Task Approach to the Functional Mapping of Brain Areas Implicated in Auditory-Verbal Memory. Brain J. Neurol. 1994, 117 Pt 6, 1271-1282. [CrossRef] [PubMed]

155. Kapur, S.; Craik, F.I.; Tulving, E.; Wilson, A.A.; Houle, S.; Brown, G.M. Neuroanatomical Correlates of Encoding in Episodic Memory: Levels of Processing Effect. Proc. Natl. Acad. Sci. USA 1994, 91, 2008-2011. [CrossRef]

156. Shallice, T.; Fletcher, P.; Frith, C.D.; Grasby, P.; Frackowiak, R.S.; Dolan, R.J. Brain Regions Associated with Acquisition and Retrieval of Verbal Episodic Memory. Nature 1994, 368, 633-635. [CrossRef] [PubMed] 
157. Tulving, E.; Kapur, S.; Markowitsch, H.J.; Craik, F.I.; Habib, R.; Houle, S. Neuroanatomical Correlates of Retrieval in Episodic Memory: Auditory Sentence Recognition. Proc. Natl. Acad. Sci. USA 1994, 91, 2012-2015. [CrossRef]

158. Andreasen, N.C.; O’Leary, D.S.; Arndt, S.; Cizadlo, T.; Hurtig, R.; Rezai, K.; Watkins, G.L.; Ponto, L.L.; Hichwa, R.D. Short-Term and Long-Term Verbal Memory: A Positron Emission Tomography Study. Proc. Natl. Acad. Sci. USA 1995, 92, 5111-5115. [CrossRef] [PubMed]

159. Fletcher, P.C.; Frith, C.D.; Grasby, P.M.; Shallice, T.; Frackowiak, R.S.; Dolan, R.J. Brain Systems for Encoding and Retrieval of Auditory-Verbal Memory. An in Vivo Study in Humans. Brain J. Neurol. 1995, 118 Pt 2, 401-416. [CrossRef]

160. Henke, K.; Buck, A.; Weber, B.; Wieser, H.G. Human Hippocampus Establishes Associations in Memory. Hippocampus 1997, 7, 249-256. [CrossRef]

161. Vieira, R.T.; Caixeta, L.; Machado, S.; Silva, A.C.; Nardi, A.E.; Arias-Carrión, O.; Carta, M.G. Epidemiology of Early-Onset Dementia: A Review of the Literature. Clin. Pract. Epidemiol. Ment. Health CP EMH 2013, 9, 88-95. [CrossRef]

162. Pick, A. Uber Die Beziehungen Der Senilen Hirnatrophie Zur Aphasie. Prag. Med. Wochenschr. 1892, 17, $165-167$.

163. Alzheimer, A. Über eigenartige Krankheitsfälle des späteren Alters. Z. Gesamte Neurol. Psychiatr. 1911, 4, 356. [CrossRef]

164. Bang, J.; Spina, S.; Miller, B.L. Non-Alzheimer's Dementia 1. Lancet 2015, 386, 1672-1682. [CrossRef]

165. Gorno-Tempini, M.L.; Hillis, A.E.; Weintraub, S.; Kertesz, A.; Mendez, M.; Cappa, S.F.; Ogar, J.M.; Rohrer, J.D.; Black, S.; Boeve, B.F.; et al. Classification of Primary Progressive Aphasia and Its Variants. Neurology 2011, 76, 1006-1014. [CrossRef]

166. Warren, J.D.; Rohrer, J.D.; Rossor, M.N. Frontotemporal Dementia. BMJ 2013, 347, f4827. [CrossRef] [PubMed]

167. Hao, L.; Zou, Z.; Tian, H.; Zhang, Y.; Zhou, H.; Liu, L. Stem Cell-Based Therapies for Ischemic Stroke. BioMed Res. Int. 2014, 2014, e468748. [CrossRef]

168. Lee, M.-C.; Jin, C.-Y.; Kim, H.-S.; Kim, J.-H.; Kim, M.-K.; Kim, H.-I.; Lee, Y.-J.; Son, Y.-J.; Kim, Y.-O.; Woo, Y.-J. Stem Cell Dynamics in an Experimental Model of Stroke. Chonnam Med. J. 2011, 47, 90-98. [CrossRef]

169. Muraro, P.A.; Pasquini, M.; Atkins, H.L.; Bowen, J.D.; Farge, D.; Fassas, A.; Freedman, M.S.; Georges, G.E.; Gualandi, F.; Hamerschlak, N.; et al. Long-Term Outcomes After Autologous Hematopoietic Stem Cell Transplantation for Multiple Sclerosis. JAMA Neurol. 2017, 74, 459-469. [CrossRef] [PubMed]

170. Muraro, P.A.; Martin, R.; Mancardi, G.L.; Nicholas, R.; Sormani, M.P.; Saccardi, R. Autologous Haematopoietic Stem Cell Transplantation for Treatment of Multiple Sclerosis. Nat. Rev. Neurol. 2017, 13, 391-405. [CrossRef] [PubMed]

171. Alexander, T.; Farge, D.; Badoglio, M.; Lindsay, J.O.; Muraro, P.A.; Snowden, J.A. Autoimmune Diseases Working Party (ADWP) of the European Society for Blood and Marrow Transplantation (EBMT) Hematopoietic Stem Cell Therapy for Autoimmune Diseases-Clinical Experience and Mechanisms. J. Autoimmun. 2018, 92, 35-46. [CrossRef]

172. Snowden, J.A.; Sharrack, B.; Akil, M.; Kiely, D.G.; Lobo, A.; Kazmi, M.; Muraro, P.A.; Lindsay, J.O. Autologous Haematopoietic Stem Cell Transplantation (AHSCT) for Severe Resistant Autoimmune and Inflammatory Diseases-A Guide for the Generalist. Clin. Med. 2018, 18, 329-334. [CrossRef]

173. Das, J.; Sharrack, B.; Snowden, J.A. Autologous Haematopoietic Stem Cell Transplantation in Multiple Sclerosis: A Review of Current Literature and Future Directions for Transplant Haematologists and Oncologists. Curr. Hematol. Malig. Rep. 2019, 14, 127-135. [CrossRef]

174. Duarte, R.F.; Labopin, M.; Bader, P.; Basak, G.W.; Bonini, C.; Chabannon, C.; Corbacioglu, S.; Dreger, P.; Dufour, C.; Gennery, A.R.; et al. Indications for Haematopoietic Stem Cell Transplantation for Haematological Diseases, Solid Tumours and Immune Disorders: Current Practice in Europe, 2019. Bone Marrow Transplant. 2019, 54, 1525-1552. [CrossRef] [PubMed]

175. Sormani, M.P.; Muraro, P.A.; Saccardi, R.; Mancardi, G. NEDA Status in Highly Active MS Can Be More Easily Obtained with Autologous Hematopoietic Stem Cell Transplantation than Other Drugs. Mult. Scler. 2017, 23, 201-204. [CrossRef]

176. Sormani, M.P.; Muraro, P.A.; Schiavetti, I.; Signori, A.; Laroni, A.; Saccardi, R.; Mancardi, G.L. Autologous Hematopoietic Stem Cell Transplantation in Multiple Sclerosis: A Meta-Analysis. Neurology 2017, 88, 2115-2122. [CrossRef] [PubMed]

177. Burt, R.K.; Balabanov, R.; Voltarelli, J.; Barreira, A.; Burman, J. Autologous Hematopoietic Stem Cell Transplantation for Multiple Sclerosis-If Confused or Hesitant, Remember: "Treat with Standard Immune Suppressive Drugs and If No Inflammation, No Response". Mult. Scler. 2012, 18, 772-775. [CrossRef]

178. Mancardi, G.; Sormani, M.P.; Muraro, P.A.; Boffa, G.; Saccardi, R. Intense Immunosuppression Followed by Autologous Haematopoietic Stem Cell Transplantation as a Therapeutic Strategy in Aggressive Forms of Multiple Sclerosis. Mult. Scler. 2018, 24, 245-255. [CrossRef]

179. Cohen, J.A.; Baldassari, L.E.; Atkins, H.L.; Bowen, J.D.; Bredeson, C.; Carpenter, P.A.; Corboy, J.R.; Freedman, M.S.; Griffith, L.M.; Lowsky, R.; et al. Autologous Hematopoietic Cell Transplantation for Treatment-Refractory Relapsing Multiple Sclerosis: Position Statement from the American Society for Blood and Marrow Transplantation. Biol. Blood Marrow Transplant. J. Am. Soc. Blood Marrow Transplant. 2019, 25, 845-854. [CrossRef]

180. Liu, Y.; Weick, J.P.; Liu, H.; Krencik, R.; Zhang, X.; Ma, L.; Zhou, G.; Ayala, M.; Zhang, S.-C. Medial Ganglionic Eminence-like Cells Derived from Human Embryonic Stem Cells Correct Learning and Memory Deficits. Nat. Biotechnol. 2013, 31, 440-447. [CrossRef]

181. Park, D.; Yang, Y.-H.; Bae, D.K.; Lee, S.H.; Yang, G.; Kyung, J.; Kim, D.; Choi, E.-K.; Lee, S.W.; Kim, G.H.; et al. Improvement of Cognitive Function and Physical Activity of Aging Mice by Human Neural Stem Cells Over-Expressing Choline Acetyltransferase. Neurobiol. Aging 2013, 34, 2639-2646. [CrossRef] 
182. Tang, J.; Xu, H.; Fan, X.; Li, D.; Rancourt, D.; Zhou, G.; Li, Z.; Yang, L. Embryonic Stem Cell-Derived Neural Precursor Cells Improve Memory Dysfunction in Abeta(1-40) Injured Rats. Neurosci. Res. 2008, 62, 86-96. [CrossRef] [PubMed]

183. Yagi, T.; Ito, D.; Okada, Y.; Akamatsu, W.; Nihei, Y.; Yoshizaki, T.; Yamanaka, S.; Okano, H.; Suzuki, N. Modeling Familial Alzheimer's Disease with Induced Pluripotent Stem Cells. Hum. Mol. Genet. 2011, 20, 4530-4539. [CrossRef] [PubMed]

184. Huang, Y.; Mucke, L. Alzheimer Mechanisms and Therapeutic Strategies. Cell 2012, 148, 1204-1222. [CrossRef] [PubMed]

185. Reiss, A.B.; Arain, H.A.; Stecker, M.M.; Siegart, N.M.; Kasselman, L.J. Amyloid Toxicity in Alzheimer's Disease. Rev. Neurosci. 2018, 29, 613-627. [CrossRef] [PubMed]

186. Saman, S.; Kim, W.; Raya, M.; Visnick, Y.; Miro, S.; Saman, S.; Jackson, B.; McKee, A.C.; Alvarez, V.E.; Lee, N.C.Y.; et al. ExosomeAssociated Tau Is Secreted in Tauopathy Models and Is Selectively Phosphorylated in Cerebrospinal Fluid in Early Alzheimer Disease. J. Biol. Chem. 2012, 287, 3842-3849. [CrossRef]

187. Lewczuk, P.; Kornhuber, J.; Vanmechelen, E.; Peters, O.; Heuser, I.; Maier, W.; Jessen, F.; Bürger, K.; Hampel, H.; Frölich, L.; et al. Amyloid Beta Peptides in Plasma in Early Diagnosis of Alzheimer's Disease: A Multicenter Study with Multiplexing. Exp. Neurol. 2010, 223, 366-370. [CrossRef] [PubMed]

188. Fiandaca, M.S.; Kapogiannis, D.; Mapstone, M.; Boxer, A.; Eitan, E.; Schwartz, J.B.; Abner, E.L.; Petersen, R.C.; Federoff, H.J.; Miller, B.L.; et al. Identification of Preclinical Alzheimer's Disease by a Profile of Pathogenic Proteins in Neurally Derived Blood Exosomes: A Case-Control Study. Alzheimers Dement. J. Alzheimers Assoc. 2015, 11, 600-607. [CrossRef] [PubMed]

189. Cheng, L.; Doecke, J.D.; Sharples, R.A.; Villemagne, V.L.; Fowler, C.J.; Rembach, A.; Martins, R.N.; Rowe, C.C.; Macaulay, S.L.; Masters, C.L.; et al. Prognostic Serum MiRNA Biomarkers Associated with Alzheimer's Disease Shows Concordance with Neuropsychological and Neuroimaging Assessment. Mol. Psychiatry 2015, 20, 1188-1196. [CrossRef] [PubMed]

190. Gui, Y.; Liu, H.; Zhang, L.; Lv, W.; Hu, X. Altered MicroRNA Profiles in Cerebrospinal Fluid Exosome in Parkinson Disease and Alzheimer Disease. Oncotarget 2015, 6, 37043-37053. [CrossRef] [PubMed]

191. Elia, C.A.; Tamborini, M.; Rasile, M.; Desiato, G.; Marchetti, S.; Swuec, P.; Mazzitelli, S.; Clemente, F.; Anselmo, A.; Matteoli, M.; et al. Intracerebral Injection of Extracellular Vesicles from Mesenchymal Stem Cells Exerts Reduced A $\beta$ Plaque Burden in Early Stages of a Preclinical Model of Alzheimer's Disease. Cells 2019, 8, 1059. [CrossRef] [PubMed]

192. Reza-Zaldivar, E.E.; Hernández-Sapiéns, M.A.; Gutiérrez-Mercado, Y.K.; Sandoval-Ávila, S.; Gomez-Pinedo, U.; Márquez-Aguirre, A.L.; Vázquez-Méndez, E.; Padilla-Camberos, E.; Canales-Aguirre, A.A. Mesenchymal Stem Cell-Derived Exosomes Promote Neurogenesis and Cognitive Function Recovery in a Mouse Model of Alzheimer's Disease. Neural Regen. Res. 2019, 14, 1626-1634. [CrossRef]

193. Li, B.; Liu, J.; Gu, G.; Han, X.; Zhang, Q.; Zhang, W. Impact of Neural Stem Cell-Derived Extracellular Vesicles on Mitochondrial Dysfunction, Sirtuin 1 Level, and Synaptic Deficits in Alzheimer's Disease. J. Neurochem. 2020, 154, e15001. [CrossRef] [PubMed]

194. Singh, B.; Mal, G.; Verma, V.; Tiwari, R.; Khan, M.I.; Mohapatra, R.K.; Mitra, S.; Alyami, S.A.; Emran, T.B.; Dhama, K.; et al. Stem cell therapies and benefaction of somatic cell nuclear transfer cloning in COVID-19 era. Stem Cell Res. Ther. 2021, 12, 1-16. [CrossRef]

195. ClinicalTrials.gov. The Safety and The Efficacy Evaluation of NEUROSTEM®-AD in Patients with Alzheimer's Disease. Available online: https: / clinicaltrials.gov /ct2/show/results / NCT01297218?view=results (accessed on 27 September 2020).

196. ClinicalTrials.gov. Efficacy and Safety of Filgrastim in Alzheimer's Disease. Available online: https://clinicaltrials.gov/ct2 / show / NCT01617577 (accessed on 4 October 2020).

197. Na, D.L. The Long-Term Safety and Efficacy Follow-up Study of Subjects Who Completed the Phase I Clinical Trial of Neurostem ${ }^{\circledR}-$ AD; Clinicaltrials.gov. 2012. Available online: https:/ / clinicaltrials.gov/ct2/show / NCT01696591 (accessed on 15 November 2020).

198. ClinicalTrials.gov. Safety and Exploratory Efficacy Study of NEUROSTEM®Versus Placebo in Patients with Alzheimer's Disease. Available online: https:/ / clinicaltrials.gov/ct2/show / NCT02054208 (accessed on 4 October 2020).

199. ClinicalTrials.gov. Allogeneic Human Mesenchymal Stem Cell Infusion Versus Placebo in Patients with Alzheimer's Disease. Available online: https:/ / clinicaltrials.gov/ct2/show / NCT02600130 (accessed on 27 September 2020).

200. ClinicalTrials.gov. Safety and Exploratory Efficacy Study of UCMSCs in Patients with Alzheimer's Disease. Available online: https: / / clinicaltrials.gov / ct2 / show / NCT02672306 (accessed on 4 October 2020).

201. ClinicalTrials.gov. Follow-up Study of Safety and Efficacy in Subjects Who Completed NEUROSTEM®Phase-I/IIa Clinical Trial. Available online: https:/ / clinicaltrials.gov/ct2/show / NCT03172117 (accessed on 4 October 2020).

202. ClinicalTrials.gov. Alzheimer's Autism and Cognitive Impairment Stem Cell Treatment Study. Available online: https:// clinicaltrials.gov / ct2/show / NCT03724136 (accessed on 27 September 2020).

203. Zinman, L.; Cudkowicz, M. Emerging Targets and Treatments in Amyotrophic Lateral Sclerosis. Lancet Neurol. 2011, 10, 481-490. [CrossRef]

204. Chiò, A.; Mora, G.; Calvo, A.; Mazzini, L.; Bottacchi, E.; Mutani, R. PARALS Epidemiology of ALS in Italy: A 10-Year Prospective Population-Based Study. Neurology 2009, 72, 725-731. [CrossRef]

205. Robberecht, W.; Philips, T. The Changing Scene of Amyotrophic Lateral Sclerosis. Nat. Rev. Neurosci. 2013, 14, 248-264. [CrossRef] [PubMed]

206. Gordon, P.; Corcia, P.; Meininger, V. New Therapy Options for Amyotrophic Lateral Sclerosis. Expert Opin. Pharmacother. 2013, 14, 1907-1917. [CrossRef] [PubMed]

207. Srivastava, A.K.; Bulte, J.W.M. Seeing Stem Cells at Work in Vivo. Stem Cell Rev. Rep. 2014, 10, 127-144. [CrossRef] 
208. Karumbayaram, S.; Novitch, B.G.; Patterson, M.; Umbach, J.A.; Richter, L.; Lindgren, A.; Conway, A.E.; Clark, A.T.; Goldman, S.A.; Plath, K.; et al. Directed Differentiation of Human-Induced Pluripotent Stem Cells Generates Active Motor Neurons. Stem Cells 2009, 27, 806-811. [CrossRef]

209. Kim, H.; Kim, H.Y.; Choi, M.R.; Hwang, S.; Nam, K.-H.; Kim, H.-C.; Han, J.S.; Kim, K.S.; Yoon, H.S.; Kim, S.H. Dose-Dependent Efficacy of ALS-Human Mesenchymal Stem Cells Transplantation into Cisterna Magna in SOD1-G93A ALS Mice. Neurosci. Lett. 2010, 468, 190-194. [CrossRef]

210. Boucherie, C.; Schäfer, S.; Lavand'homme, P.; Maloteaux, J.-M.; Hermans, E. Chimerization of Astroglial Population in the Lumbar Spinal Cord after Mesenchymal Stem Cell Transplantation Prolongs Survival in a Rat Model of Amyotrophic Lateral Sclerosis. J. Neurosci. Res. 2009, 87, 2034-2046. [CrossRef]

211. Ohnishi, S.; Ito, H.; Suzuki, Y.; Adachi, Y.; Wate, R.; Zhang, J.; Nakano, S.; Kusaka, H.; Ikehara, S. Intra-Bone Marrow-Bone Marrow Transplantation Slows Disease Progression and Prolongs Survival in G93A Mutant SOD1 Transgenic Mice, an Animal Model Mouse for Amyotrophic Lateral Sclerosis. Brain Res. 2009, 1296, 216-224. [CrossRef] [PubMed]

212. Corti, S.; Nizzardo, M.; Nardini, M.; Donadoni, C.; Salani, S.; Simone, C.; Falcone, M.; Riboldi, G.; Govoni, A.; Bresolin, N.; et al. Systemic Transplantation of C-Kit+ Cells Exerts a Therapeutic Effect in a Model of Amyotrophic Lateral Sclerosis. Hum. Mol. Genet. 2010, 19, 3782-3796. [CrossRef] [PubMed]

213. Corti, S.; Locatelli, F.; Papadimitriou, D.; Del Bo, R.; Nizzardo, M.; Nardini, M.; Donadoni, C.; Salani, S.; Fortunato, F.; Strazzer, S.; et al. Neural Stem Cells LewisX+ CXCR4+ Modify Disease Progression in an Amyotrophic Lateral Sclerosis Model. Brain J. Neurol. 2007, 130, 1289-1305. [CrossRef] [PubMed]

214. Xu, L.; Yan, J.; Chen, D.; Welsh, A.M.; Hazel, T.; Johe, K.; Hatfield, G.; Koliatsos, V.E. Human Neural Stem Cell Grafts Ameliorate Motor Neuron Disease in SOD-1 Transgenic Rats. Transplantation 2006, 82, 865-875. [CrossRef] [PubMed]

215. Abdelalim, E.M.; Bonnefond, A.; Bennaceur-Griscelli, A.; Froguel, P. Pluripotent Stem Cells as a Potential Tool for Disease Modelling and Cell Therapy in Diabetes. Stem Cell Rev. Rep. 2014, 10, 327-337. [CrossRef] [PubMed]

216. Cnop, M.; Welsh, N.; Jonas, J.-C.; Jörns, A.; Lenzen, S.; Eizirik, D.L. Mechanisms of Pancreatic Beta-Cell Death in Type 1 and Type 2 Diabetes: Many Differences, Few Similarities. Diabetes 2005, 54 Suppl. 2, S97-S107. [CrossRef] [PubMed]

217. Al-Khawaga, S.; Memon, B.; Butler, A.E.; Taheri, S.; Abou-Samra, A.B.; Abdelalim, E.M. Pathways Governing Development of Stem Cell-Derived Pancreatic $\beta$ Cells: Lessons from Embryogenesis. Biol. Rev. Camb. Philos. Soc. 2018, 93, 364-389. [CrossRef] [PubMed]

218. van der Torren, C.R.; Zaldumbide, A.; Duinkerken, G.; Brand-Schaaf, S.H.; Peakman, M.; Stangé, G.; Martinson, L.; Kroon, E.; Brandon, E.P.; Pipeleers, D.; et al. Immunogenicity of Human Embryonic Stem Cell-Derived Beta Cells. Diabetologia 2017, 60, 126-133. [CrossRef]

219. Roscioni, S.S.; Migliorini, A.; Gegg, M.; Lickert, H. Impact of Islet Architecture on $\beta$-Cell Heterogeneity, Plasticity and Function. Nat. Rev. Endocrinol. 2016, 12, 695-709. [CrossRef]

220. Chandrakasan, S.; Malik, P. Gene Therapy for Hemoglobinopathies: The State of the Field and the Future. Hematol. Oncol. Clin. North Am. 2014, 28, 199-216. [CrossRef]

221. Zhang, M.; Methot, D.; Poppa, V.; Fujio, Y.; Walsh, K.; Murry, C.E. Cardiomyocyte Grafting for Cardiac Repair: Graft Cell Death and Anti-Death Strategies. J. Mol. Cell. Cardiol. 2001, 33, 907-921. [CrossRef]

222. Shirai, T.; Rao, V.; Weisel, R.D.; Ikonomidis, J.S.; Li, R.K.; Tumiati, L.C.; Merante, F.; Mickle, D.A. Preconditioning Human Cardiomyocytes and Endothelial Cells. J. Thorac. Cardiovasc. Surg. 1998, 115, 210-219. [CrossRef]

223. Jiang, S.; Haider, H.K.; Idris, N.M.; Salim, A.; Ashraf, M. Supportive Interaction between Cell Survival Signaling and Angiocompetent Factors Enhances Donor Cell Survival and Promotes Angiomyogenesis for Cardiac Repair. Circ. Res. 2006, 99, 776-784. [CrossRef]

224. Yau, T.M.; Kim, C.; Ng, D.; Li, G.; Zhang, Y.; Weisel, R.D.; Li, R.-K. Increasing Transplanted Cell Survival with Cell-Based Angiogenic Gene Therapy. Ann. Thorac. Surg. 2005, 80, 1779-1786. [CrossRef] [PubMed]

225. Shintani, S.; Kusano, K.; Ii, M.; Iwakura, A.; Heyd, L.; Curry, C.; Wecker, A.; Gavin, M.; Ma, H.; Kearney, M.; et al. Synergistic Effect of Combined Intramyocardial CD34+Cells and VEGF2 Gene Therapy after MI. Nat. Clin. Pract. Cardiovasc. Med. 2006, 3 (Suppl. 1), S123-S128. [CrossRef] [PubMed]

226. Christman, K.L.; Vardanian, A.J.; Fang, Q.; Sievers, R.E.; Fok, H.H.; Lee, R.J. Injectable Fibrin Scaffold Improves Cell Transplant Survival, Reduces Infarct Expansion, and Induces Neovasculature Formation in Ischemic Myocardium. J. Am. Coll. Cardiol. 2004, 44, 654-660. [CrossRef]

227. Kutschka, I.; Chen, I.Y.; Kofidis, T.; Arai, T.; von Degenfeld, G.; Sheikh, A.Y.; Hendry, S.L.; Pearl, J.; Hoyt, G.; Sista, R.; et al. Collagen Matrices Enhance Survival of Transplanted Cardiomyoblasts and Contribute to Functional Improvement of Ischemic Rat Hearts. Circulation 2006, 114, I167-I173. [CrossRef] [PubMed]

228. Feigin, V.L.; Forouzanfar, M.H.; Krishnamurthi, R.; Mensah, G.A.; Connor, M.; Bennett, D.A.; Moran, A.E.; Sacco, R.L.; Anderson, L.; Truelsen, T.; et al. Global and Regional Burden of Stroke during 1990-2010: Findings from the Global Burden of Disease Study 2010. Lancet Lond. Engl. 2014, 383, 245-254. [CrossRef]

229. Langhorne, P.; Bernhardt, J.; Kwakkel, G. Stroke Rehabilitation. Lancet Lond. Engl. 2011, 377, 1693-1702. [CrossRef]

230. Hankey, G.J. Stroke. Lancet Lond. Engl. 2017, 389, 641-654. [CrossRef] 
231. Kalladka, D.; Sinden, J.; Pollock, K.; Haig, C.; McLean, J.; Smith, W.; McConnachie, A.; Santosh, C.; Bath, P.M.; Dunn, L.; et al. Human Neural Stem Cells in Patients with Chronic Ischaemic Stroke (PISCES): A Phase 1, First-in-Man Study. Lancet 2016, 388, 787-796. [CrossRef]

232. Chen, L.; Zhang, G.; Gu, Y.; Guo, X. Meta-Analysis and Systematic Review of Neural Stem Cells Therapy for Experimental Ischemia Stroke in Preclinical Studies. Sci. Rep. 2016, 6, 32291. [CrossRef]

233. Chen, L.; Zhang, G.; Khan, A.A.; Guo, X.; Gu, Y. Clinical Efficacy and Meta-Analysis of Stem Cell Therapies for Patients with Brain Ischemia. Stem Cells Int. 2016, 2016, 6129579. [CrossRef] [PubMed]

234. Nakagomi, N.; Nakagomi, T.; Kubo, S.; Nakano-Doi, A.; Saino, O.; Takata, M.; Yoshikawa, H.; Stern, D.M.; Matsuyama, T.; Taguchi, A. Endothelial Cells Support Survival, Proliferation, and Neuronal Differentiation of Transplanted Adult Ischemia-Induced Neural Stem/Progenitor Cells after Cerebral Infarction. Stem Cells 2009, 27, 2185-2195. [CrossRef]

235. Müller, F.-J.; Snyder, E.Y.; Loring, J.F. Gene Therapy: Can Neural Stem Cells Deliver? Nat. Rev. Neurosci. 2006, 7, 75-84. [CrossRef]

236. Christian, K.M.; Song, H.; Ming, G. Functions and Dysfunctions of Adult Hippocampal Neurogenesis. Annu. Rev. Neurosci. 2014, 37, 243-262. [CrossRef]

237. Chollet, F.; Cramer, S.C.; Stinear, C.; Kappelle, L.J.; Baron, J.C.; Weiller, C.; Azouvi, P.; Hommel, M.; Sabatini, U.; Moulin, T.; et al. Pharmacological Therapies in Post Stroke Recovery: Recommendations for Future Clinical Trials. J. Neurol. 2014, 261, 1461-1468. [CrossRef] [PubMed]

238. Kelly, S.; Bliss, T.M.; Shah, A.K.; Sun, G.H.; Ma, M.; Foo, W.C.; Masel, J.; Yenari, M.A.; Weissman, I.L.; Uchida, N.; et al. Transplanted Human Fetal Neural Stem Cells Survive, Migrate, and Differentiate in Ischemic Rat Cerebral Cortex. Proc. Natl. Acad. Sci. USA 2004, 101, 11839-11844. [CrossRef] [PubMed]

239. Martino, G.; Pluchino, S. The Therapeutic Potential of Neural Stem Cells. Nat. Rev. Neurosci. 2006, 7, 395-406. [CrossRef]

240. Li, J.; Tang, Y.; Wang, Y.; Tang, R.; Jiang, W.; Yang, G.-Y.; Gao, W.-Q. Neurovascular Recovery via Cotransplanted Neural and Vascular Progenitors Leads to Improved Functional Restoration after Ischemic Stroke in Rats. Stem Cell Rep. 2014, 3, 101-114. [CrossRef] [PubMed]

241. Ullah, M.; Ng, N.N.; Concepcion, W.; Thakor, A.S. Emerging Role of Stem Cell-Derived Extracellular MicroRNAs in AgeAssociated Human Diseases and in Different Therapies of Longevity. Ageing Res. Rev. 2020, 57, 100979. [CrossRef] [PubMed]

242. Barzegar, M.; Wang, Y.; Yun, J.W.; Chernyshev, O.; Kelley, R.; Alexander, J.S. Abstract TP102: Human Placental Mesenchymal Stem Cells Derived Exosome-Angiotensin Converting Enzyme-2 Dependent Protection in Ischemic Stroke Injury. Stroke 2020, 51, ATP102. [CrossRef]

243. Wang, C.; Börger, V.; Sardari, M.; Murke, F.; Skuljec, J.; Pul, R.; Hagemann, N.; Dzyubenko, E.; Dittrich, R.; Gregorius, J.; et al. Mesenchymal Stromal Cell-Derived Small Extracellular Vesicles Induce Ischemic Neuroprotection by Modulating Leukocytes and Specifically Neutrophils. Stroke 2020, 51, 1825-1834. [CrossRef] [PubMed]

244. Moon, G.J.; Sung, J.H.; Kim, D.H.; Kim, E.H.; Cho, Y.H.; Son, J.P.; Cha, J.M.; Bang, O.Y. Application of Mesenchymal Stem Cell-Derived Extracellular Vesicles for Stroke: Biodistribution and MicroRNA Study. Transl. Stroke Res. 2019, 10, 509-521. [CrossRef] [PubMed]

245. Sun, X.; Jung, J.-H.; Arvola, O.; Santoso, M.R.; Giffard, R.G.; Yang, P.C.; Stary, C.M. Stem Cell-Derived Exosomes Protect Astrocyte Cultures From in vitro Ischemia and Decrease Injury as Post-Stroke Intravenous Therapy. Front. Cell. Neurosci. 2019, 13, 394. [CrossRef]

246. Wei, L.; Wei, Z.Z.; Jiang, M.Q.; Mohamad, O.; Yu, S.P. Stem Cell Transplantation Therapy for Multifaceted Therapeutic Benefits after Stroke. Prog. Neurobiol. 2017, 157, 49-78. [CrossRef]

247. Borlongan, C.V.; Koutouzis, T.K.; Jorden, J.R.; Martinez, R.; Rodriguez, A.I.; Poulos, S.G.; Freeman, T.B.; McKeown, P.; Cahill, D.W.; Nishino, H.; et al. Neural Transplantation as an Experimental Treatment Modality for Cerebral Ischemia. Neurosci. Biobehav. Rev. 1997, 21, 79-90. [CrossRef]

248. Liska, M.G.; Crowley, M.G.; Nguyen, H.; Borlongan, C.V. Biobridge Concept in Stem Cell Therapy for Ischemic Stroke. J. Neurosurg. Sci. 2017, 61, 173-179. [CrossRef] [PubMed]

249. Zhao, L.-R.; Duan, W.-M.; Reyes, M.; Keene, C.D.; Verfaillie, C.M.; Low, W.C. Human Bone Marrow Stem Cells Exhibit Neural Phenotypes and Ameliorate Neurological Deficits after Grafting into the Ischemic Brain of Rats. Exp. Neurol. 2002, 174, 11-20. [CrossRef]

250. Kurozumi, K.; Nakamura, K.; Tamiya, T.; Kawano, Y.; Kobune, M.; Hirai, S.; Uchida, H.; Sasaki, K.; Ito, Y.; Kato, K.; et al. BDNF Gene-Modified Mesenchymal Stem Cells Promote Functional Recovery and Reduce Infarct Size in the Rat Middle Cerebral Artery Occlusion Model. Mol. Ther. J. Am. Soc. Gene Ther. 2004, 9, 189-197. [CrossRef]

251. Veizovic, T.; Beech, J.S.; Stroemer, R.P.; Watson, W.P.; Hodges, H. Resolution of Stroke Deficits Following Contralateral Grafts of Conditionally Immortal Neuroepithelial Stem Cells. Stroke 2001, 32, 1012-1019. [CrossRef]

252. Modo, M.; Rezaie, P.; Heuschling, P.; Patel, S.; Male, D.K.; Hodges, H. Transplantation of Neural Stem Cells in a Rat Model of Stroke: Assessment of Short-Term Graft Survival and Acute Host Immunological Response. Brain Res. 2002, 958, 70-82. [CrossRef]

253. Nagai, A.; Kim, W.K.; Lee, H.J.; Jeong, H.S.; Kim, K.S.; Hong, S.H.; Park, I.H.; Kim, S.U. Multilineage Potential of Stable Human Mesenchymal Stem Cell Line Derived from Fetal Marrow. PLoS ONE 2007, 2, e1272. [CrossRef] 
254. Lee, H.J.; Kim, K.S.; Kim, E.J.; Choi, H.B.; Lee, K.H.; Park, I.H.; Ko, Y.; Jeong, S.W.; Kim, S.U. Brain Transplantation of Immortalized Human Neural Stem Cells Promotes Functional Recovery in Mouse Intracerebral Hemorrhage Stroke Model. Stem Cells 2007, 25, 1204-1212. [CrossRef]

255. Abeysinghe, H.C.S.; Bokhari, L.; Quigley, A.; Choolani, M.; Chan, J.; Dusting, G.J.; Crook, J.M.; Kobayashi, N.R.; Roulston, C.L. Pre-Differentiation of Human Neural Stem Cells into GABAergic Neurons Prior to Transplant Results in Greater Repopulation of the Damaged Brain and Accelerates Functional Recovery after Transient Ischemic Stroke. Stem Cell Res. Ther. 2015, 6, 186. [CrossRef]

256. Drury-Stewart, D.; Song, M.; Mohamad, O.; Guo, Y.; Gu, X.; Chen, D.; Wei, L. Highly Efficient Differentiation of Neural Precursors from Human Embryonic Stem Cells and Benefits of Transplantation after Ischemic Stroke in Mice. Stem Cell Res. Ther. 2013, 4, 93. [CrossRef]

257. Bühnemann, C.; Scholz, A.; Bernreuther, C.; Malik, C.Y.; Braun, H.; Schachner, M.; Reymann, K.G.; Dihné, M. Neuronal Differentiation of Transplanted Embryonic Stem Cell-Derived Precursors in Stroke Lesions of Adult Rats. Brain J. Neurol. 2006, 129, 3238-3248. [CrossRef] [PubMed]

258. Chau, M.J.; Deveau, T.C.; Song, M.; Gu, X.; Chen, D.; Wei, L. IPSC Transplantation Increases Regeneration and Functional Recovery after Ischemic Stroke in Neonatal Rats. Stem Cells 2014, 32, 3075-3087. [CrossRef]

259. Nakazaki, M.; Sasaki, M.; Kataoka-Sasaki, Y.; Oka, S.; Namioka, T.; Namioka, A.; Onodera, R.; Suzuki, J.; Sasaki, Y.; Nagahama, H.; et al. Intravenous Infusion of Mesenchymal Stem Cells Inhibits Intracranial Hemorrhage after Recombinant Tissue Plasminogen Activator Therapy for Transient Middle Cerebral Artery Occlusion in Rats. J. Neurosurg. 2017, 127, 917-926. [CrossRef] [PubMed]

260. Chen, J.; Sanberg, P.R.; Li, Y.; Wang, L.; Lu, M.; Willing, A.E.; Sanchez-Ramos, J.; Chopp, M. Intravenous Administration of Human Umbilical Cord Blood Reduces Behavioral Deficits after Stroke in Rats. Stroke 2001, 32, 2682-2688. [CrossRef] [PubMed]

261. Chen, J.; Zhang, Z.G.; Li, Y.; Wang, L.; Xu, Y.X.; Gautam, S.C.; Lu, M.; Zhu, Z.; Chopp, M. Intravenous Administration of Human Bone Marrow Stromal Cells Induces Angiogenesis in the Ischemic Boundary Zone After Stroke in Rats. Circ. Res. 2003, 92, 692-699. [CrossRef] [PubMed]

262. Jeong, S.-W.; Chu, K.; Jung, K.-H.; Kim, S.U.; Kim, M.; Roh, J.-K. Human Neural Stem Cell Transplantation Promotes Functional Recovery in Rats with Experimental Intracerebral Hemorrhage. Stroke 2003, 34, 2258-2263. [CrossRef]

263. Toyoshima, A.; Yasuhara, T.; Kameda, M.; Morimoto, J.; Takeuchi, H.; Wang, F.; Sasaki, T.; Sasada, S.; Shinko, A.; Wakamori, T.; et al. Intra-Arterial Transplantation of Allogeneic Mesenchymal Stem Cells Mounts Neuroprotective Effects in a Transient Ischemic Stroke Model in Rats: Analyses of Therapeutic Time Window and Its Mechanisms. PLoS ONE 2015, 10, e0127302. [CrossRef]

264. Fukuda, Y.; Horie, N.; Satoh, K.; Yamaguchi, S.; Morofuji, Y.; Hiu, T.; Izumo, T.; Hayashi, K.; Nishida, N.; Nagata, I. Intra-Arterial Transplantation of Low-Dose Stem Cells Provides Functional Recovery without Adverse Effects after Stroke. Cell. Mol. Neurobiol. 2015, 35, 399-406. [CrossRef]

265. Wei, Z.Z.; Gu, X.; Ferdinand, A.; Lee, J.H.; Ji, X.; Ji, X.M.; Yu, S.P.; Wei, L. Intranasal Delivery of Bone Marrow Mesenchymal Stem Cells Improved Neurovascular Regeneration and Rescued Neuropsychiatric Deficits after Neonatal Stroke in Rats. Cell Transplant. 2015, 24, 391-402. [CrossRef]

266. Nelson, P.T.; Kondziolka, D.; Wechsler, L.; Goldstein, S.; Gebel, J.; DeCesare, S.; Elder, E.M.; Zhang, P.J.; Jacobs, A.; McGrogan, M.; et al. Clonal Human (HNT) Neuron Grafts for Stroke Therapy: Neuropathology in a Patient 27 Months after Implantation. Am. J. Pathol. 2002, 160, 1201-1206. [CrossRef]

267. Hallett, P.J.; Cooper, O.; Sadi, D.; Robertson, H.; Mendez, I.; Isacson, O. Long-Term Health of Dopaminergic Neuron Transplants in Parkinson's Disease Patients. Cell Rep. 2014, 7, 1755-1761. [CrossRef] [PubMed]

268. Stem Cell Therapies as an Emerging Paradigm in Stroke Participants. Stem Cell Therapies as an Emerging Paradigm in Stroke (STEPS): Bridging Basic and Clinical Science for Cellular and Neurogenic Factor Therapy in Treating Stroke. Stroke 2009, 40, 510-515. [CrossRef]

269. Savitz, S.I.; Chopp, M.; Deans, R.; Carmichael, T.; Phinney, D.; Wechsler, L. STEPS Participants Stem Cell Therapy as an Emerging Paradigm for Stroke (STEPS) II. Stroke 2011, 42, 825-829. [CrossRef] [PubMed]

270. Liu, X.; Ye, R.; Yan, T.; Yu, S.P.; Wei, L.; Xu, G.; Fan, X.; Jiang, Y.; Stetler, R.A.; Liu, G.; et al. Cell Based Therapies for Ischemic Stroke: From Basic Science to Bedside. Prog. Neurobiol. 2014, 115, 92-115. [CrossRef] [PubMed]

271. Kondziolka, D.; Wechsler, L.; Goldstein, S.; Meltzer, C.; Thulborn, K.R.; Gebel, J.; Jannetta, P.; DeCesare, S.; Elder, E.M.; McGrogan, M.; et al. Transplantation of Cultured Human Neuronal Cells for Patients with Stroke. Neurology 2000, 55, 565-569. [CrossRef] [PubMed]

272. Kondziolka, D.; Steinberg, G.K.; Wechsler, L.; Meltzer, C.C.; Elder, E.; Gebel, J.; Decesare, S.; Jovin, T.; Zafonte, R.; Lebowitz, J.; et al. Neurotransplantation for Patients with Subcortical Motor Stroke: A Phase 2 Randomized Trial. J. Neurosurg. 2005, 103, 38-45. [CrossRef] [PubMed]

273. Bang, O.Y.; Lee, J.S.; Lee, P.H.; Lee, G. Autologous Mesenchymal Stem Cell Transplantation in Stroke Patients. Ann. Neurol. 2005, 57, 874-882. [CrossRef] [PubMed]

274. Savitz, S.I.; Dinsmore, J.; Wu, J.; Henderson, G.V.; Stieg, P.; Caplan, L.R. Neurotransplantation of Fetal Porcine Cells in Patients with Basal Ganglia Infarcts: A Preliminary Safety and Feasibility Study. Cerebrovasc. Dis. 2005, 20, 101-107. [CrossRef] 
275. Sharma, A.; Sane, H.; Gokulchandran, N.; Khopkar, D.; Paranjape, A.; Sundaram, J.; Gandhi, S.; Badhe, P. Autologous Bone Marrow Mononuclear Cells Intrathecal Transplantation in Chronic Stroke. Stroke Res. Treat. 2014, 2014, 234095. [CrossRef] [PubMed]

276. Suárez-Monteagudo, C.; Hernández-Ramírez, P.; Alvarez-González, L.; García-Maeso, I.; de la Cuétara-Bernal, K.; Castillo-Díaz, L.; Bringas-Vega, M.L.; Martínez-Aching, G.; Morales-Chacón, L.M.; Báez-Martín, M.M.; et al. Autologous Bone Marrow Stem Cell Neurotransplantation in Stroke Patients. An Open Study. Restor. Neurol. Neurosci. 2009, 27, 151-161. [CrossRef] [PubMed]

277. Battistella, V.; de Freitas, G.R.; da Fonseca, L.M.B.; Mercante, D.; Gutfilen, B.; Goldenberg, R.C.S.; Dias, J.V.; Kasai-Brunswick, T.H.; Wajnberg, E.; Rosado-de-Castro, P.H.; et al. Safety of Autologous Bone Marrow Mononuclear Cell Transplantation in Patients with Nonacute Ischemic Stroke. Regen. Med. 2011, 6, 45-52. [CrossRef]

278. Honmou, O.; Houkin, K.; Matsunaga, T.; Niitsu, Y.; Ishiai, S.; Onodera, R.; Waxman, S.G.; Kocsis, J.D. Intravenous Administration of Auto Serum-Expanded Autologous Mesenchymal Stem Cells in Stroke. Brain J. Neurol. 2011, 134, 1790-1807. [CrossRef]

279. Li, Z.-M.; Zhang, Z.-T.; Guo, C.-J.; Geng, F.-Y.; Qiang, F.; Wang, L.-X. Autologous Bone Marrow Mononuclear Cell Implantation for Intracerebral Hemorrhage-a Prospective Clinical Observation. Clin. Neurol. Neurosurg. 2013, 115, 72-76. [CrossRef]

280. Friedrich, M.A.G.; Martins, M.P.; Araújo, M.D.; Klamt, C.; Vedolin, L.; Garicochea, B.; Raupp, E.F.; Sartori El Ammar, J.; Machado, D.C.; Costa, J.C.d.; et al. Intra-Arterial Infusion of Autologous Bone Marrow Mononuclear Cells in Patients with Moderate to Severe Middle Cerebral Artery Acute Ischemic Stroke. Cell Transplant. 2012, 21 (Suppl. 1), S13-S21. [CrossRef]

281. Azad, T.D.; Veeravagu, A.; Steinberg, G.K. Neurorestoration after Stroke. Neurosurg. Focus 2016, 40, E2. [CrossRef]

282. Kwak, K.-A.; Kwon, H.-B.; Lee, J.W.; Park, Y.-S. Current Perspectives Regarding Stem Cell-Based Therapy for Ischemic Stroke. Curr. Pharm. Des. 2018, 24, 3332-3340. [CrossRef]

283. Moniche, F.; Escudero, I.; Zapata-Arriaza, E.; Usero-Ruiz, M.; Prieto-León, M.; de la Torre, J.; Gamero, M.-A.; Tamayo, J.A.; Ochoa-Sepúlveda, J.-J.; Maestre, J.; et al. Intra-Arterial Bone Marrow Mononuclear Cells (BM-MNCs) Transplantation in Acute Ischemic Stroke (IBIS Trial): Protocol of a Phase II, Randomized, Dose-Finding, Controlled Multicenter Trial. Int. J. Stroke Off. J. Int. Stroke Soc. 2015, 10, 1149-1152. [CrossRef] [PubMed]

284. Palisade Bio. Available online: https:/ / www.palisadebio.com/overview/default.aspx (accessed on 2 May 2021).

285. Fang, J.; Guo, Y.; Tan, S.; Li, Z.; Xie, H.; Chen, P.; Wang, K.; He, Z.; He, P.; Ke, Y.; et al. Autologous Endothelial Progenitor Cells Transplantation for Acute Ischemic Stroke: A 4-Year Follow-Up Study. Stem Cells Transl. Med. 2019, 8, 14-21. [CrossRef] [PubMed]

286. Van Pham, P.; Truong, N.C.; Le, P.T.-B.; Tran, T.D.-X.; Vu, N.B.; Bui, K.H.-T.; Phan, N.K. Isolation and Proliferation of Umbilical Cord Tissue Derived Mesenchymal Stem Cells for Clinical Applications. Cell Tissue Bank. 2016, 17, 289-302. [CrossRef]

287. Dobrzański, L.A. Biomaterials in Regenerative Medicine; BoD—Books on Demand: Norderstedt, Germany, 2018; ISBN 978-953-513776-4.

288. Weiss, J.N.; Levy, S. Neurologic Stem Cell Treatment Study (NEST) Using Bone Marrow Derived Stem Cells for the Treatment of Neurological Disorders and Injuries: Study Protocol for a Nonrandomized Efficacy Trial. Available online: https://www.

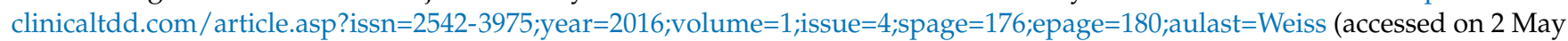
2021).

289. Toyoda, K. Epidemiology and Registry Studies of Stroke in Japan. J. Stroke 2013, 15, 21-26. [CrossRef]

290. Mackie, A.R.; Losordo, D.W. CD34-Positive Stem Cells: In the Treatment of Heart and Vascular Disease in Human Beings. Tex. Heart Inst. J. 2011, 38, 474-485. [PubMed]

291. Heldring, N.; Mäger, I.; Wood, M.J.A.; Le Blanc, K.; Andaloussi, S.E.L. Therapeutic Potential of Multipotent Mesenchymal Stromal Cells and Their Extracellular Vesicles. Hum. Gene Ther. 2015, 26, 506-517. [CrossRef]

292. ReNeuron. Available online: http:/ / www.reneuron.com/ (accessed on 2 May 2021)

293. Stevanato, L.; Hicks, C.; Sinden, J.D. Differentiation of a Human Neural Stem Cell Line on Three Dimensional Cultures, Analysis of MicroRNA and Putative Target Genes. J. Vis. Exp. JoVE 2015, 12, 52410. [CrossRef]

294. Athersys, Inc. Available online: https://www.athersys.com/home/default.aspx (accessed on 2 May 2021).

295. Xie, B.; Chen, M.; Hu, R.; Han, W.; Ding, S. Therapeutic Evidence of Human Mesenchymal Stem Cell Transplantation for Cerebral Palsy: A Meta-Analysis of Randomized Controlled Trials. Stem Cells Int. 2020, 2020, 5701920. [CrossRef]

296. Pathipati, P.; Lecuyer, M.; Faustino, J.; Strivelli, J.; Phinney, D.G.; Vexler, Z.S. Mesenchymal Stem Cell (MSC)-Derived Extracellular Vesicles Protect from Neonatal Stroke by Interacting with Microglial Cells. Neurotherapeutics 2021, 18, 1939-1952. [CrossRef]

297. Stonesifer, C.; Corey, S.; Ghanekar, S.; Diamandis, Z.; Acosta, S.A.; Borlongan, C.V. Stem Cell Therapy for Abrogating StrokeInduced Neuroinflammation and Relevant Secondary Cell Death Mechanisms. Prog. Neurobiol. 2017, 158, 94-131. [CrossRef]

298. Whitton, P.S. Inflammation as a Causative Factor in the Aetiology of Parkinson's Disease. Br. J. Pharmacol. 2007, 150, 963-976. [CrossRef] [PubMed]

299. Stolp, H.B. Neuropoietic Cytokines in Normal Brain Development and Neurodevelopmental Disorders. Mol. Cell. Neurosci. 2013, 53, 63-68. [CrossRef]

300. Raman, D.; Sobolik-Delmaire, T.; Richmond, A. Chemokines in Health and Disease. Exp. Cell Res. 2011, 317, 575-589. [CrossRef]

301. Barone, F.C.; Feuerstein, G.Z. Inflammatory Mediators and Stroke: New Opportunities for Novel Therapeutics. J. Cereb. Blood Flow Metab. Off. J. Int. Soc. Cereb. Blood Flow Metab. 1999, 19, 819-834. [CrossRef] [PubMed]

302. Sinning, C.; Westermann, D.; Clemmensen, P. Oxidative Stress in Ischemia and Reperfusion: Current Concepts, Novel Ideas and Future Perspectives. Biomark. Med. 2017, 11, 11031-11040. [CrossRef] [PubMed] 
303. Vandooren, J.; Van Damme, J.; Opdenakker, G. On the Structure and Functions of Gelatinase B/Matrix Metalloproteinase-9 in Neuroinflammation. Prog. Brain Res. 2014, 214, 193-206. [CrossRef] [PubMed]

304. Jayaraj, R.L.; Azimullah, S.; Beiram, R.; Jalal, F.Y.; Rosenberg, G.A. Neuroinflammation: Friend and Foe for Ischemic Stroke. J. Neuroinflammation 2019, 16, 142. [CrossRef]

305. Borlongan, C.V.; Glover, L.E.; Sanberg, P.R.; Hess, D.C. Permeating the Blood Brain Barrier and Abrogating the Inflammation in Stroke: Implications for Stroke Therapy. Curr. Pharm. Des. 2012, 18, 3670-3676. [CrossRef] [PubMed]

306. Lakhan, S.E.; Kirchgessner, A.; Hofer, M. Inflammatory Mechanisms in Ischemic Stroke: Therapeutic Approaches. J. Transl. Med. 2009, 7, 97. [CrossRef] [PubMed]

307. Ceulemans, A.-G.; Zgavc, T.; Kooijman, R.; Hachimi-Idrissi, S.; Sarre, S.; Michotte, Y. The Dual Role of the Neuroinflammatory Response after Ischemic Stroke: Modulatory Effects of Hypothermia. J. Neuroinflamm. 2010, 7, 74. [CrossRef] [PubMed]

308. Iadecola, C.; Anrather, J. The Immunology of Stroke: From Mechanisms to Translation. Nat. Med. 2011, 17, 796-808. [CrossRef]

309. Park, D.-H.; Borlongan, C.V.; Willing, A.E.; Eve, D.J.; Cruz, L.E.; Sanberg, C.D.; Chung, Y.-G.; Sanberg, P.R. Human Umbilical Cord Blood Cell Grafts for Brain Ischemia. Cell Transplant. 2009, 18, 985-998. [CrossRef] [PubMed]

310. Park, D.-H.; Eve, D.J.; Musso, J.; Klasko, S.K.; Cruz, E.; Borlongan, C.V.; Sanberg, P.R. Inflammation and Stem Cell Migration to the Injured Brain in Higher Organisms. Stem Cells Dev. 2009, 18, 693-702. [CrossRef]

311. Dailey, T.; Metcalf, C.; Mosley, Y.I.; Sullivan, R.; Shinozuka, K.; Tajiri, N.; Pabon, M.; Acosta, S.; Kaneko, Y.; van Loveren, H.; et al. An Update on Translating Stem Cell Therapy for Stroke from Bench to Bedside. J. Clin. Med. 2013, 2, 220-241. [CrossRef]

312. Borlongan, C.V.; Sanberg, P.R.; Freeman, T.B. Neural Transplantation for Neurodegenerative Disorders. Lancet 1999, 353 (Suppl. 1), SI29-SI30. [CrossRef]

313. Borlongan, C.V.; Kaneko, Y.; Maki, M.; Yu, S.-J.; Ali, M.; Allickson, J.G.; Sanberg, C.D.; Kuzmin-Nichols, N.; Sanberg, P.R. Menstrual Blood Cells Display Stem Cell-like Phenotypic Markers and Exert Neuroprotection Following Transplantation in Experimental Stroke. Stem Cells Dev. 2010, 19, 439-452. [CrossRef]

314. Antonucci, I.; Stuppia, L.; Kaneko, Y.; Yu, S.; Tajiri, N.; Bae, E.C.; Chheda, S.H.; Weinbren, N.L.; Borlongan, C.V. Amniotic Fluid as a Rich Source of Mesenchymal Stromal Cells for Transplantation Therapy. Cell Transplant. 2011, 20, 789-795. [CrossRef]

315. Stevanato, L.; Thanabalasundaram, L.; Vysokov, N.; Sinden, J.D. Investigation of Content, Stoichiometry and Transfer of MiRNA from Human Neural Stem Cell Line Derived Exosomes. PLoS ONE 2016, 11, e0146353. [CrossRef]

316. Takahashi, K.; Yamanaka, S. Induction of Pluripotent Stem Cells from Mouse Embryonic and Adult Fibroblast Cultures by Defined Factors. Cell 2006, 126, 663-676. [CrossRef]

317. Drela, K.; Siedlecka, P.; Sarnowska, A.; Domanska-Janik, K. Human Mesenchymal Stem Cells in the Treatment of Neurological Diseases. Acta Neurobiol. Exp. 2013, 73, 38-56.

318. Kim, S.U.; Lee, H.J.; Kim, Y.B. Neural Stem Cell-Based Treatment for Neurodegenerative Diseases. Neuropathol. Off. J. Jpn. Soc. Neuropathol. 2013, 33, 491-504. [CrossRef]

319. Tang, S.-C.; Arumugam, T.V.; Xu, X.; Cheng, A.; Mughal, M.R.; Jo, D.G.; Lathia, J.D.; Siler, D.A.; Chigurupati, S.; Ouyang, X.; et al. Pivotal Role for Neuronal Toll-like Receptors in Ischemic Brain Injury and Functional Deficits. Proc. Natl. Acad. Sci. USA 2007, 104, 13798-13803. [CrossRef] [PubMed]

320. Tang, Y.; Yasuhara, T.; Hara, K.; Matsukawa, N.; Maki, M.; Yu, G.; Xu, L.; Hess, D.C.; Borlongan, C.V. Transplantation of Bone Marrow-Derived Stem Cells: A Promising Therapy for Stroke. Cell Transplant. 2007, 16, 159-169. [CrossRef]

321. Zhang, W.; Gu, G.-J.; Shen, X.; Zhang, Q.; Wang, G.-M.; Wang, P.-J. Neural Stem Cell Transplantation Enhances Mitochondrial Biogenesis in a Transgenic Mouse Model of Alzheimer's Disease-like Pathology. Neurobiol. Aging 2015, 36, 1282-1292. [CrossRef] [PubMed]

322. Xuan, A.G.; Luo, M.; Ji, W.D.; Long, D.H. Effects of Engrafted Neural Stem Cells in Alzheimer's Disease Rats. Neurosci. Lett. 2009, 450, 167-171. [CrossRef]

323. Laroni, A.; de Rosbo, N.K.; Uccelli, A. Mesenchymal Stem Cells for the Treatment of Neurological Diseases: Immunoregulation beyond Neuroprotection. Immunol. Lett. 2015, 168, 183-190. [CrossRef]

324. Comi, C.; Tondo, G. Insights into the Protective Role of Immunity in Neurodegenerative Disease. Neural Regen. Res. 2017, 12, 64-65. [CrossRef] [PubMed]

325. Venkataramana, N.K.; Kumar, S.K.V.; Balaraju, S.; Radhakrishnan, R.C.; Bansal, A.; Dixit, A.; Rao, D.K.; Das, M.; Jan, M.; Gupta, P.K.; et al. Open-Labeled Study of Unilateral Autologous Bone-Marrow-Derived Mesenchymal Stem Cell Transplantation in Parkinson's Disease. Transl. Res. J. Lab. Clin. Med. 2010, 155, 62-70. [CrossRef]

326. Bowman, M.; Racke, M.; Kissel, J.; Imitola, J. Responsibilities of Health Care Professionals in Counseling and Educating Patients With Incurable Neurological Diseases Regarding "Stem Cell Tourism": Caveat Emptor. JAMA Neurol. 2015, 72, 1342-1345. [CrossRef]

327. Tajiri, N.; Duncan, K.; Antoine, A.; Pabon, M.; Acosta, S.A.; de la Pena, I.; Hernadez-Ontiveros, D.G.; Shinozuka, K.; Ishikawa, H.; Kaneko, Y.; et al. Stem Cell-Paved Biobridge Facilitates Neural Repair in Traumatic Brain Injury. Front. Syst. Neurosci. $2014,8,116$. [CrossRef]

328. Chen, J.; Chopp, M. Neurorestorative Treatment of Stroke: Cell and Pharmacological Approaches. NeuroRx J. Am. Soc. Exp. Neurother. 2006, 3, 466-473. [CrossRef]

329. Sanchez-Ramos, J.; Song, S.; Cardozo-Pelaez, F.; Hazzi, C.; Stedeford, T.; Willing, A.; Freeman, T.B.; Saporta, S.; Janssen, W.; Patel, N.; et al. Adult Bone Marrow Stromal Cells Differentiate into Neural Cells in Vitro. Exp. Neurol. 2000, 164, 247-256. [CrossRef] 
330. Smith, A.G. Embryo-Derived Stem Cells: Of Mice and Men. Annu. Rev. Cell Dev. Biol. 2001, 17, 435-462. [CrossRef] [PubMed]

331. Zhang, X.; Stojkovic, P.; Przyborski, S.; Cooke, M.; Armstrong, L.; Lako, M.; Stojkovic, M. Derivation of Human Embryonic Stem Cells from Developing and Arrested Embryos. Stem Cells 2006, 24, 2669-2676. [CrossRef] [PubMed]

332. Thomson, J.A.; Itskovitz-Eldor, J.; Shapiro, S.S.; Waknitz, M.A.; Swiergiel, J.J.; Marshall, V.S.; Jones, J.M. Embryonic Stem Cell Lines Derived from Human Blastocysts. Science 1998, 282, 1145-1147. [CrossRef] [PubMed]

333. Reubinoff, B.E.; Pera, M.F.; Fong, C.Y.; Trounson, A.; Bongso, A. Embryonic Stem Cell Lines from Human Blastocysts: Somatic Differentiation in Vitro. Nat. Biotechnol. 2000, 18, 399-404. [CrossRef]

334. Volarevic, V.; Markovic, B.S.; Gazdic, M.; Volarevic, A.; Jovicic, N.; Arsenijevic, N.; Armstrong, L.; Djonov, V.; Lako, M.; Stojkovic, M. Ethical and Safety Issues of Stem Cell-Based Therapy. Int. J. Med. Sci. 2018, 15, 36-45. [CrossRef] [PubMed]

335. Riley, J.; Glass, J.; Feldman, E.L.; Polak, M.; Bordeau, J.; Federici, T.; Johe, K.; Boulis, N.M. Intraspinal Stem Cell Transplantation in Amyotrophic Lateral Sclerosis: A Phase I Trial, Cervical Microinjection, and Final Surgical Safety Outcomes. Neurosurgery 2014, 74, 77-87. [CrossRef]

336. Sakata, H.; Narasimhan, P.; Niizuma, K.; Maier, C.M.; Wakai, T.; Chan, P.H. Interleukin 6-Preconditioned Neural Stem Cells Reduce Ischaemic Injury in Stroke Mice. Brain J. Neurol. 2012, 135, 3298-3310. [CrossRef]

337. Hicks, A.U.; Lappalainen, R.S.; Narkilahti, S.; Suuronen, R.; Corbett, D.; Sivenius, J.; Hovatta, O.; Jolkkonen, J. Transplantation of Human Embryonic Stem Cell-Derived Neural Precursor Cells and Enriched Environment after Cortical Stroke in Rats: Cell Survival and Functional Recovery. Eur. J. Neurosci. 2009, 29, 562-574. [CrossRef]

338. Wu, P.; Tarasenko, Y.I.; Gu, Y.; Huang, L.-Y.M.; Coggeshall, R.E.; Yu, Y. Region-Specific Generation of Cholinergic Neurons from Fetal Human Neural Stem Cells Grafted in Adult Rat. Nat. Neurosci. 2002, 5, 1271-1278. [CrossRef] [PubMed]

339. Darsalia, V.; Kallur, T.; Kokaia, Z. Survival, Migration and Neuronal Differentiation of Human Fetal Striatal and Cortical Neural Stem Cells Grafted in Stroke-Damaged Rat Striatum. Eur. J. Neurosci. 2007, 26, 605-614. [CrossRef]

340. Faiz, M.; Sachewsky, N.; Gascón, S.; Bang, K.W.A.; Morshead, C.M.; Nagy, A. Adult Neural Stem Cells from the Subventricular Zone Give Rise to Reactive Astrocytes in the Cortex after Stroke. Cell Stem Cell 2015, 17, 624-634. [CrossRef] [PubMed]

341. Péron, S.; Berninger, B. Imported Stem Cells Strike against Stroke. Cell Stem Cell 2015, 17, 501-502. [CrossRef] [PubMed]

342. Sirko, S.; Behrendt, G.; Johansson, P.A.; Tripathi, P.; Costa, M.; Bek, S.; Heinrich, C.; Tiedt, S.; Colak, D.; Dichgans, M.; et al. Reactive Glia in the Injured Brain Acquire Stem Cell Properties in Response to Sonic Hedgehog. Cell Stem Cell 2013, 12, $426-439$. [CrossRef] [PubMed]

343. Zhang, G.-L.; Zhu, Z.-H.; Wang, Y.-Z. Neural Stem Cell Transplantation Therapy for Brain Ischemic Stroke: Review and Perspectives. World J. Stem Cells 2019, 11, 817-830. [CrossRef] [PubMed]

344. Gögel, S.; Gubernator, M.; Minger, S.L. Progress and Prospects: Stem Cells and Neurological Diseases. Gene Ther. 2011, 18, 1-6. [CrossRef]

345. Yoo, J.; Kim, H.-S.; Hwang, D.-Y. Stem Cells as Promising Therapeutic Options for Neurological Disorders. J. Cell. Biochem. 2013, 114, 743-753. [CrossRef] [PubMed]

346. Le Blanc, K.; Rasmusson, I.; Sundberg, B.; Götherström, C.; Hassan, M.; Uzunel, M.; Ringdén, O. Treatment of Severe Acute Graft-versus-Host Disease with Third Party Haploidentical Mesenchymal Stem Cells. Lancet 2004, 363, 1439-1441. [CrossRef]

347. Burt, R.K.; Traynor, A.E.; Oyama, Y.; Barr, W.G. Plasticity of Hematopoietic Stem Cells: Enough to Induce Tolerance and Repair Tissue? Arthritis Rheum. Off. J. Am. Coll. Rheumatol. 2002, 46, 855-858. [CrossRef]

348. Burt, R.K.; Verda, L.; Kim, D.-A.; Oyama, Y.; Luo, K.; Link, C. Embryonic Stem Cells As an Alternate Marrow Donor Source: Engraftment without Graft-Versus-Host Disease. J. Exp. Med. 2004, 199, 895-904. [CrossRef] [PubMed]

349. Siniscalco, D.; Kannan, S.; Semprún-Hernández, N.; Eshraghi, A.A.; Brigida, A.L.; Antonucci, N. Stem Cell Therapy in Autism: Recent Insights. Stem Cells Cloning Adv. Appl. 2018, 11, 55-67. [CrossRef] [PubMed]

350. Sharma, A.; Gokulchandran, N.; Sane, H.; Nagrajan, A.; Paranjape, A.; Kulkarni, P.; Shetty, A.; Mishra, P.; Kali, M.; Biju, H.; et al. Autologous Bone Marrow Mononuclear Cell Therapy for Autism: An Open Label Proof of Concept Study. Stem Cells Int. 2013, 2013, 623875. [CrossRef] [PubMed]

351. Herberts, C.A.; Kwa, M.S.; Hermsen, H.P. Risk Factors in the Development of Stem Cell Therapy. J. Transl. Med. 2011, 9, 29. [CrossRef] [PubMed]

352. Hough, R.E.; Snowden, J.A.; Wulffraat, N.M. Haemopoietic Stem Cell Transplantation in Autoimmune Diseases: A European Perspective. Br. J. Haematol. 2005, 128, 432-459. [CrossRef] [PubMed]

353. Cao, Q.; Benton, R.L.; Whittemore, S.R. Stem Cell Repair of Central Nervous System Injury. J. Neurosci. Res. 2002, 68, 501-510. [CrossRef] 